CRUSTACEAN PARASITES OF WEST INDIAN FISHES AND LAND CRABS, WITH DESCRIPTIONS OF NEW GENERA AND SPECIES.

\author{
By Charles Branch Wilson, \\ Department of Biology, State Normal School, Westfield, Massachusetts.
}

\title{
INTRODUCTORY.
}

During the summer of 1910 the author enjoyed the privilege of spending three months at the biological laboratory of Johns Hopkins University at Montego Bay, Jamaica.

As a part of the work there accomplished about 100 species of fish, including many hundreds of specimens, were examined for parasitic copepods, isopods, and other parasites that might be of peculiar interest.

Many of the larger crustacea, and in particular the land crabs, were also examined for the same purpose, and several peculiar and unexpected parasites were found upon their gills.

And finally different kinds of ascidians, of which many species live upon the mangrove roots around the Bogue Islands about a mile to the west of the town, and upon the ocean bottom in that vicinity, were carefully examined in order to obtain the various copepods, isopods, and amphipods, which are commensals or semiparasites within them.

The present paper gives the results of these examinations and is chiefly concerned with the copepods although one new species of ostracod is described. For the opportunity of prosecuting this study and for the excellent laboratory privileges which were furnished sincere thanks are returned to the authorities of the Johns Hopkins University. To Dr. E. A. Andrews, the director of the laboratory, the author is indebted for valuable suggestions and advice. And to the authorities of the United States National Museum a deep obligation for much timely assistance in this and many other similar investigations is acknowledged. 


\section{FISH AND FISHERIES.}

The region around Montego Bay is the center of the most extensive fisheries in Jamaica. Every part of the harbor and the shore for 10 or 15 miles to the east and west of the town contributes some fish to the market.

The methods employed in catching these fish are rather crude, both the boats and the apparatus used being primitive and not very well constructed. The boats are practically all small dugouts made from native trees, and the fishing tackle consists of pots and traps, haul seines, gill nets, cast nets, and hand lines. By far the largest number of fish are taken in the pots, which consist of a wooden framework covered with split cane, bamboo, or in recent years with wire netting.

These pots are scattered all over the bottom, where it is smooth, both inside and outside of the coral reefs, in water from 1 to 12 fathoms deep, and are pulled every morning before the sea breeze roughens the surface. The haul seines are also used extensively along the numerous sandy beaches.

The actual number of food fishes obtained, as well as the number of species, is quite large, and by requesting the fishermen to save such kinds as are usually thrown away or used for bait, the number of species can readily be doubled. There were brought in for examination during the past season about 100 recorded species, nearly all of which were caught in fish pots.

A very little effort with the seine and line fishermen would easily increase this number. Again the supply of all the common species is constant for long periods of time, the same kinds being obtained daily, thus insuring an abundance of fresh material for work either with the fish themselves or with their parasites.

Of the selachians the sharks are rather scarce, only a few hammerheads (Sphyrna zygæna) and one or two species of Carcharhinus being caught during the summer, but they are said to be more plentiful at other seasons. To offset this scarcity of sharks there is an abundance of sting (Dasyatidæ) and eagle (Myliobatidæ) rays, the former often of very large size.

Among the bony fish the grunts (Hæmulidæ), the sea basses and groupers (Serranidæ), and the parrot fishes (Scaridæ) are especially numerous. The mullets (Mugilidæ), the pompanos (Carangidæ), the snappers (Lutianidæ), the croakers (Sciænidæ), and the butterfly and angel fishes (Chætodontidæ) are also abundant. The pipefishes, (Sygnathidæ), the trunk-fishes (Ostraciidæ), the puffers (Tetraodontidæ), and the porcupine fishes (Diodontidæ) can be obtained almost everywhere and in large numbers. 
Beside these forms, which may be designated as the regular catch, odd species are continually being taken both in the fish pots and in the seines, and if the fishermen be induced to save these and bring them in for examination it will be found that they include during the season a good representation of nearly every family that occurs in the West Indies. In this way may often be obtained the remora (Echeneis naucrates), the sea-bat (Ogcocephalus vespertilio), the spotted moray (Lycodontis moringa), the cutlass fish (Trichiurus lepturus), the galliwasp (Synodus foetans), and the flying gurnard (Cephalacanthus volitans), together with a host of other odd forms.

Many of the marine fish run far up into the fresh-water rivers, especially the mullets and pipefishes, but there are about a dozen strictly fresh-water species, including two or three darters, mudfish, catfish, and the like. These are not often caught by the natives but may easily be obtained with a seine. All the rivers are swift and turbulent streams except for the short deadwater near their mouths, and during the rainy season they become powerful torrents, sweeping down into the sea everything that gets caught in their current. At such times no fish can be obtained from the rivers, and even under favorable conditions the supply is limited. To escape being swept away many of the fish have acquired the habit of burrowing under the rocks or going into holes in the banks, which adds to the difficulty of securing them.

On low land to the west of the town, between the Montego River and the ocean, is a portion of the old bed of the river, which now forms a good-sized pond filled with brackish water and plentifully supplied with fish and crustacea.

This combination of salt, fresh, and brackish water furnishes exceptional facilities for the study of fish and their parasites. And it would be difficult to find a region better suited for such investigation than Montego Bay and the immediate vicinity.

\section{PARASITIC ISOPODS.}

As might be expected, parasites of all kinds were fairly common in Jamaica. But while there was a wide diversity of form and nearly every animal was more or less infested with them, the actual numbers were remarkably small. More parasites have repeatedly been taken from a single fish at Woods Hole, Massachusetts, or on the coast of Maine, than could be obtained from a score of them here in Jamaica, and to a certain extent the same was true of the crustacea and ascidians that were examined; there was the same dearth of numbers.

The parasitic isopods were about the only exception to this general rule. In the temperate regions of both the Atlantic and Pacific oceans these parasites are quite rare, but here in the tropics they are 
abundant and surpass in numbers all the other parasites together. They swarm in the eye sockets and the mouth and gill cavities of many of the common fish, and are especially abundant upon the parrot fish, the grunts, and the snappers. Other species are found living as commensals within the bodies of ascidians, sponges, and the like.

A large number of specimens were obtained from these various hosts and were sent to the United States National Museum for identification and study. ${ }^{1}$

\section{PARASITIC COPEPODS.}

As has just been stated with reference to the isopods, it was found that a careful examination of any large fish would usually yield copepod parasites. But while there was an abundance of the isopods there would be only one or two, or at most a very few, copepods. And even large catches of fish were always disappointing in the number of copepods obtained from them. The result has been a collection of copepod parasites, very meager in the number of specimens, but comparatively rich in the number of species.

In the following list an effort has been made to include all the copepods previously reported from West Indian fish along with those found during the present investigations.

Nearly all of these published species are included in two papers, both of which are confined, so far as the West Indies are concerned, to the Danish islands in the group of Lesser Antilles.

The first paper ${ }^{2}$ was written by Steenstrup and Lütken and published in 1861, and the second by Krøyer, ${ }^{3}$ published in 1863.

Many of the species which they reported were obtained from preserved specimens of Danish West Indian fish in the Vienna Museum while others were brought home by the captains of various vessels which had cruised in that portion of the Atlantic.

So far as can be ascertained not a single species has hitherto been described from living material.

The present report is the exact antithesis of this, for every new species here presented has been described, and the drawings have been made, from living specimens before preservation, and in addition some of the Danish species, published in the two papers above mentioned, were obtained alive from Jamaican fish, and upon them were verified the original specific descriptions. In all there are here included 52 species, of which 21 have been previously described, while 31 are new to science.

\footnotetext{
1 See Richardson, Proc. U. S. Nat. Mus., vol. 42, No. 1894, April 5, 1912, pp. 187-192.

2 Kong. Danske Vid. Selsk. Skrivt., 5te. Raekke, p. 343.

${ }^{3}$ Naturh. Tidsskr., 3die. Raekke, p. 75.
} 


\section{Family ARGULID $\circledast$.}

The apparent absence of this family from the fauna of Jamaica is worthy of comment. Species of Argulus have been obtained from Key West, Florida; from New Orleans, Louisiana; from Dallas, Texas, and from many localities in Central and South America. These include both salt and fresh water forms and show that in the surrounding faunas, which most resemble that of Jamaica, the family Argulidæ is fairly well represented. Hence we should naturally look for a similar representation in the Jamaican fauna, and it seems more reasonable to suppose that the failure to discover any member of this family on the fish of Jamaica has been the result of accident rather than due to their entire absence from the region. Careful search in the future may bring to light some Argulus species, but a similar search during the season of 1910 was unsuccessful.

\section{Family ERGASILIDÆ.}

\section{ERGASILUS LONGIPALPUS, new species.}

Plate 18, figs. 1-6.

Host and record of specimens.-A single lot, consisting of six females, was taken from the gills of several puffers (Chilomycterus antennatus) at Montego Bay, June 6, 1910.

Type-specimen.-Cat. No. 43512, U.S.N.M. Paratypes, Cat. No. 42258, U.S.N.M.

Female.-Cephalothorax ovate, one-fourth longer than wide, with evenly curved lateral, and a slightly reentrant posterior, margin; neither dorsal grooves nor eye visible. The first three free thorax segments the same length, but diminishing regularly in width, the first one (second segment) three-sevenths the width of the carapace; fifth segment indistinguishably fused with the genital segment, which is the same width and about twice the length of the fourth segment. Abdomen two-thirds the width of the genital segment and made up of three joints of equal length; anal laminæ small and circular, each tipped with two setæ, the inner of which is twice the length of the outer. Egg-tubes narrowed posteriorly, two-thirds the body length; eggs small, in six or eight longitudinal rows, about 20 eggs in a row.

First antennæ of the usual pattern; second pair with moderately enlarged basal joints and a stout terminal claw, bent sharply near the center and armed there with a rounded protuberance on the inner margin.

Mandibles with a şlender neck, a narrow terminal blade, armed with setæ along the inner border only, and a large secondary tuft of setæ at the inner distal corner of the neck.

Mandibular palps exceptionally long and narrow, reaching beyond the tip of the basal joint almost to the center of the terminal blade. $69077^{\circ}$-Proc.N.M.vol.44-13-13 
In this they are peculiar, since in other"species the tip of the palp does not project beyond the end of the basal joint. First maxilla a large knob, armed with two equal setæ; second maxilla with a large and stout basal joint and a short terminal blade, which does not reach the midline; terminal tuft of setæ short and dense.

Rami of swimming legs three-jointed, except the exopod of the fourth pair, which has but two joints; arrangement of spines and setæ as follows: First exopod, I-0, $0-1,0-6$; endopod, $0-1,0-2$, $\mathrm{I}-4$. Second exopod, I-0, I-1, 0-6; endopod, $0-1,0-2, \mathrm{I}-5$. Third exopod, $0-0,0-1,0-6$; endopod, $0-1,0-1,0-5$. Fourth exopod, I-0, $0-5$; endopod, $0-0,0-2,0-4$. Fifth legs wholly lacking.

Color a uniform cartilage gray, without pigment markings of any sort, quickly becoming light brown in preservatives.

Total length, $1.20 \mathrm{~mm}$. Cephalothorax, $0.75 \mathrm{~mm}$. long, $0.6 \mathrm{~mm}$. wide. Genital segment, $0.1 \mathrm{~mm}$. long and the same width. Egg strings, $0.76 \mathrm{~mm}$. long, $0.20 \mathrm{~mm}$. wide.

(longus, long, and palpus, a palp, alluding to the exceptional length of the mandibular palps.)

This species is difficult to distinguish except by the mouth parts, where the projection of the long and narrow palps beyond the tips of the basal mandibular joints, and the short terminal joints of the second maxillæ are very noticeable.

\section{ERGASILUS MYCTAROTHES, new species.}

Plate 18, figs. $7-12$.

Host and record of specimens.-Seven females of this species, four of which carried egg strings, were taken from the mucus in the nasal tubes of a hammer-head shark, Sphyrna zygæna.

Type-specimen.-Cat. No. 43597, U.S.N.M. Paratypes, Cat. No. 42255, U.S.N.M.

Female.-General body form elongate and narrow; carapace elliptical, nearly twice as long as wide, narrowed about equally anteriorly and posteriorly, with shallow, but distinct, notches in the lateral margins two-fifths of the length from the posterior end, which indicate the point of union of the head with the first thorax segment. Free thorax and abdomen only two-fifths as long as the carapace and tapering rapidly posteriorly; second, third, and fourth segments the same length, but diminishing regularly in width; fifth segment so completely fused with the genital segment that there is no indication of the union either in a groove or in a pair of pdimentary fifth legs. Genital segment barrel-shaped, a little wider than long, with convex lateral margins and a pair of short, broadly rounded posterior lobes.

Abdomen three-jointed, joints diminishing regularly in length and width; terminal joint with a deep anal incision; anal laminæ con- 
siderably longer than the basal abdomen joint and half as wide as the terminal joint, enlarged at the tip and armed with two large setæ, the inner of which is four times the length of the outer. Eggcases cylindrical, as long as the entire body and twice the diameter of the genital segment; eggs rather small, in five or six longitudinal rows, from 20 to 25 in each row.

First antennæ short, only reaching the center of the basal joint of the second pair, and sparsely armed with setæ.

Second antennæ stout and two-thirds the length of the cephalothorax; basal joint moderately enlarged, the remainder of the appendage tapering regularly, with a small knob on the inner margin of the penultimate joint close to the base of the terminal claw; the latter with two small teeth on its inner margin near the center.

Labrum only indistinctly visible; mandibles large and stout, the terminal blade broad and armed with setæ around its entire margin; palps very narrow and needle-like, as long as the terminal blade and with a row of fine teeth along their outer margin; first maxillæ small, not projecting much, and armed with two small plumose setæ; second maxillæ rather large, but with small terminal joints, which overlap at the midline and are heavily armed with setæ; no visible traces of the maxillipeds.

The first three pairs of swimming legs with three-jointed rami, the exopod of the fourth pair with two joints only; the arrangement of the spines and setæ as follows: First exopod, I-0, I-0, $0-6$; endopod, $0-1,0-2,0-5$. Second exopod, I-0, I-1, $0-6$; endopod, $\mathrm{I}-1,0-2,0-6$. Third exopod, I-0, I-1, $0-5$; endopod, I-1, $0-2,0-6$. Fourth exopod, I-0, $0-5$; endopod, I-1, I-2, $0-5$.

Color a uniform cartilage gray without pigment or markings of any sort.

Total length, $0.95 \mathrm{~mm}$. Cephalothorax, $0.7 \mathrm{~mm}$. long, $0.4 \mathrm{~mm}$. wide. Egg-strings, $0.9 \mathrm{~mm}$. long, $0.18 \mathrm{~mm}$. wide.

(

This new species may be distinguished from others by the elongate elliptical shape of the cephalothorax, by the extreme shortness of the body behind the cephalothorax (see above measurements), by the great length and uniform diameter of the egg-cases, and by the thickness of the "neck" of the mandible, the width of its cutting blade, and the linear form of its palp.

BOMOLOCHUS NOTHRUS, new species.

Plates 19 and 20.

Host and record of specimens.-Fifteen specimens, including both sexes, were obtained from the gill cavity of the little fish locally known as "sheepshead," Abudefduf saxatilis, on September 5. 
A single female was found on the gills of a tobacco fish, Aleutera scripta, but as this fish had been tumbled into the boat with the sheepsheads the copepod probably got on to it in some way from the latter. This single specimen is numbered 42257, U.S.N.M.

Type-specimen.-A female, Cat. No. 43590, U.S.N.M. Paratypes, Cat. No. 42253 , U.S.N.M.

Female.-General body form rather short and stout; carapace twice as wide as long, squarely truncated posteriorly and with a shallow notch at the center of the frontal margin. Second, third, and fourth segments subequal in length, but diminishing regularly in width. Second segment one-third narrower than the carapace, leaving the first legs visible on either side; a part of the basal joints as well as the rami of the other swimming legs visible dorsally. Fifth segment the same length as the fourth and only a little narrower; genital segment the same width as the fifth segment and rather short, with convex sides.

Abdomen two-jointed, the basal joint wider but shorter than the terminal; anal laminæ small and rectangular, each tipped with a long inner seta, a shorter outer one, and two spines, one at the outer distal corner, the other at the center of the outer border.

Egg-strings four-sevenths of the entire length, the same width as the genital segment, and slightly narrowed at the posterior end; eggs in five or six longitudinal rows, from 15 to 16 eggs in each row.

First antennæ prominent; basal portion considerably widened and strongly arched, carrying two long tactile setæ toward its distal end. Second pair large and stout, the terminal joint tipped with two large finger-like processes, one dorsal and considerably smaller, the other ventral, and between them two long, curved claws and a straight spine. A row of bluntly rounded comb teeth runs along the anterior margin of each finger process and on to the joint itself; the row from the dorsal process stops at about the center of the joint while that from the ventral process runs the whole length of the anterior margin of the joint and curves around its proximal end to the posterior margin.

Upper lip triangular, nearly twice as wide as long, with straight sides and well rounded corners. Mandibles bent sharply backward and ending in a straight and slender spine.

First maxillæ with a long curved paragnath and a prominent knob armed with three plumose setæ, of which the two inner ones are close together, curved inward toward the midline and then backward, and are four times the length of the outer one, which is removed a little distance from them and points directly backward.

Second maxillæ curved forward and inward, not quite meeting at the midline, their terminal blades armed with a row of short hairs along the anterior margin. Maxillipeds with a large triangular basal 
joint and a rather slender, strongly curved terminal claw, with a long accessory spine at the posterior curve of the S.

First swimming legs with a two-jointed exopod and a three-jointed endopod, the remaining legs with three-jointed rami, the arrangement of the spines and setæ as follows: Second exopod, I-0, I-1, II -5 ; endopod, $0-1,0-2$, II-3. Third exopod, I-0, I-1, III-5; endopod, I-1, I-2, I-3. Fourth exopod, $1-0, \mathrm{I}-1$, II -5 ; endopod, $0-1,0-1, \mathrm{I}-2$. Fifth legs two-jointed, the basal joint much shorter than the terminal and at an angle with the latter, which is tipped with three spines of equal length.

Color a translucent cartilage gray, the ovaries, oviducts, and external egg-cases white.

Total length, $2.45 \mathrm{~mm}$. Carapace, $0.65 \mathrm{~mm}$. long, $1.3 \mathrm{~mm}$. wide. Free segments, $1 \mathrm{~mm}$. long. Egg-strings, $1.45 \mathrm{~mm}$. long.

Male.-General body form wider than usual; carapace transversely elliptical, one-half wider than long, forming a blunt point on each lateral and on the frontal margin. Second, third, fourth, and fifth thorax segments the same length but diminishing regularly in width, and leaving the whole of the swimming legs visible in dorsal view. Genital segment the same width as the fourth segment, elongate acorn-shaped, with a squarely truncated posterior border and prominent well-rounded posterior corners.

Abdomen half the width of the genital segment and much shorter, two-jointed, the joints equal; anal laminæ quadrilateral, a little longer than wide and armed as in the female.

Basal portion of the first antennæ narrower and straighter than in the female; second antennæ and mouth parts the same except the maxillipeds. These are in normal position behind the other mouth parts and are three-jointed; the second joint is stout with its posterior margin swollen into a pad entirely covered with short spines which increase in size toward the distal end; the terminal claw is slender, three-fourths the length of the second joint, slightly curved, and armed along its inner margin with a row of minute saw teeth, which shut down against the spiny pad on the second joint.

Swimming legs jointed as in the female but quite differently armed; the basal exopod joint of the first pair carries a very large and flattened plumose seta on its outer margin; the terminal exopod joint of the second, third, and fourth pairs is armed with two medium spines on the outer margin and a third twice the length, or even more, at the tip; the fifth legs are smaller than in the female but similarly two-jointed.

Color the same but lacking the white of the female reproductive organs, so that the male appears considerably darker.

Total length, $1.10 \mathrm{~mm}$. Carapace, $0.36 \mathrm{~mm}$. long, $0.52 \mathrm{~mm}$. wide. Free thorax, $0.28 \mathrm{~mm}$. long.

( $\nu \omega \theta$ pòs, slow or sluggish.) 
This species is large and fairly common in the gill cavities of the little sheepsheads. But it is noticeably sluggish in its movements and never leaves the fish on the death of the latter. On being removed and placed in an aquarium, it swims but little, attaching itself to one spot and remaining there for a long time. Even the male is not active, and in contrast with other species appears very slow and lazy.

BOMOLOCHUS ATTENUATUS, new species.

Plate 21.

Host and record of specimens. - Three females, two of which carried external egg-strings, were taken in company with Artacolax palleucus on the gills of the so-called "poison grouper," really one of the scorpion fishes, Scorpæna plumieri, August 6, 1910.

Type-specimen.-Cat. No. 43511, U.S.N.M. Paratypes, Cat. No. 42266, U.S.N.M.

Female.-General body form very elongate and slender; cephalothorax semielliptical, two-thirds wider than long, with almost regular curvature; eye small and close to the frontal margin.

Second thorax segment short, one-seventh narrower than the cephalothorax; third segment longer and three-quarters as wide as the second; fourth segment only half the length and width of the third; fifth segment as long as the third and one-fifth narrower than the fourth, formed into a sort of neck anteriorly and posteriorly. Genital segment barrel-shaped, the same width as the fifth segment and twice as long.

Abdomen nearly as long as the free thorax and genital segment together, three-jointed, the joints diminishing a little in length and width; anal laminæ twice as long as wide, and two-thirds the length of the last segment, with square corners. Each is tipped with a long: inner seta, an outer one half as long, a short spine at the outer distal corner, and another at the center of the outer margin.

Egg-strings remarkably long and slender for this genus, as long as the entire body and the same width as the basal abdomen segment, which makes them 11 times as long as wide; eggs large, arranged in four longitudinal rows, from 25 to 27 in a row.

First antennæ very long and slender, the basal portion only slightly enlarged and not much curved, but carrying two long tactile setæ, and the usual large plumose seta at the distal end, pointing backward.

Second antennæ large and stout, the terminal joint tipped with a long finger process at the posterior ventral corner, a shorter one at the anterior ventral corner, with two long and strongly curved claws between them, and a larger curved claw arising from the dorsal sur- 
face above the bases of the two finger processes. The whole ventral surface of the joint itself and that of the two processes are covered with diagonal corrugations.

The upper lip is one-half wider than long, with convex anterior and posterior margins, prominent lateral angles, and a small rounded process at the center of the posterior margin. It is further ornamented on the ventral surface with a wide ridge, curving inward from each lateral angle, then backward to the posterior margin, and then inward again to the median process.

The mandibles are turned backward along the posterior margin of the lip and terminate in a straight and slender spine.

The first maxillæ are each armed with three setæ, the two inner ones close together and the same length, the outer one removed a little ways from them and only one-fifth as long.

The second maxillæ are rather slender, the terminal joint being inclined forward and ending in a single smooth spine. The maxillipeds have a triangular basal joint and a stout terminal claw armed with a small and slender seta on the inner margin of the proximal curve and a large accessory spine on the outer margin of the distal curve; the basal joint carries two stout spines close together at the center of its inner margin, the anterior one twice the size of the posterior.

The first swimming legs have a two-jointed exopod and a threejointed endopod; the second, third, and fourth legs have threejointed rami, with the spines and setæ arranged as follows: Second exopod, I-0, I-1, III-5; endopod, $0-1,0-2$, II -3 . Third exopod, I-0, II $-1, \mathrm{II}-6$; endopod, $0-1,0-2, \mathrm{II}-2$. Fourth exopod, $\mathrm{I}-0, \mathrm{I}-1,0-5$; endopod, $0-1,0-1,0-3$.

Color a translucent cartilage gray, oviducts white, egg-strings light gray.

Total length, $2.28 \mathrm{~mm}$. Cephalothorax, $0.6 \mathrm{~mm}$. long, $1 \mathrm{~mm}$. wide. Free and genital segments, $1 \mathrm{~mm}$. long. Abdomen, $0.9 \mathrm{~mm}$. long. Egg-strings, $2.10 \mathrm{~mm}$. long.

(attenuatus, very slender, alluding to the first antennæ, abdomen, and egg-strings.)

This species is readily distinguished by the great length and slenderness of its first antennæ, abdomen, and egg-strings, by the armature of the terminal joint of the second antennæ, and by the peculiar shape and ornamentation of the upper lip.

It is not at all a common species, since it was found on only one of the many scorpion fish examined; it is, of course, possible that this is not its regular host, but it was not found on any of the other fish examined during the season of 1910 . 
TUCCA IMPRESSUS Krøyer.

Tucca impressus KR $\phi \mathrm{YER}, 1837$, p. 479, pl. 5. fig. 2a-g.

Host and record of specimens.-This species was very common on the fins of the various puffers, and almost every fish yielded one or more specimens of the parasite. Two lots were taken from the spinybacked puffer, Spheroides marmoratus, one on June 20, the other on September 15, and have been numbered, respectively, 42265 and 42269, U.S.N.M. Two other lots were obtained from the burr fish, Chilomycterus antennatus, one on June 15, the other on August 8. These include by far the larger number of specimens and also both sexes of the parasite, and have been numbered, respectively, 42273 and 42251, U.S.N.M.

A single lot was obtained from the pectoral fins of the porcupine fish, Diodon Fystrix, and has received Cat. No. 42264, U.S.N.M. This lot contains five females.

Careful search was made on these porcupine fishes for specimens of the distinct species described by Nordmann in 1864, as obtained from a Diodon species on the west coast of Africa, and to which the present author has elsewhere given the name verrucosus, ${ }^{1}$ but none could be found.

In evidence that the habitat of these (and other) parasites is exactly restricted to certain kinds of fish, we may note the fact that although this species was so common on all the puffers, not a solitary specimen was ever found on any of the trunk fishes, and yet the latter are always associated with the puffers and are very similar to them in most respects.

\section{ARTACOLAX PALLEUCUS, new species.}

Plates 22 and 23.

Host and record of specimens.-This species was common on the gills of the "poison grouper," really one of the scorpion fishes, Scorpæna plumieri Bloch.

Four lots of specimens were obtained from this fish, on June 17, June 30, July 20, and July 21, 1910. These have received respectively Cat. Nos. 42272, 42324, 42252, and 42254, U.S.N.M.

Type-specimen.-A female, Cat. No. 43582, U.S.N.M.

Female.-General shape resembling a tadpole, with a large and highly inflated cephalothorax and a long and slender hind body, made up of the fifth and sixth (genital) thorax segments and the abdomen. Head and first thorax segment fully fused; second, third, and fourth segments partially fused with them to form the anterior inflated portion of the body, which is quite regularly oval in general outline, strongly arched dorsally, and filled with the uter- 
ine processes of the oviducts. The true cephalothorax forms about two-thirds of this anterior body and is one-half wider than long; the second segment is narrowed a little and is quite short; the fused third and fourth segments are again narrowed a little, but are rounded out posteriorly over the fifth segment, so as to be nearly twice the length of the second segment.

A minute eye is plainly visible, placed far forward, very close to the anterior margin.

In the hinder portion of the body the fifth segment is abruptly narrowed to less than half the width of the fused third and fourth segments, and is mostly concealed in dorsal view.

The genital segment is a little wider than the fifth segment anteriorly where the egg-strings are attached, but tapers posteriorly.

The abdomen is made up of three long and narrow segments, diminishing regularly in size, the basal one the same length as the genital segment. The anal laminæ are as long as the terminal abdomen segment, and each of them half as wide, tapering posteriorly and tipped with an inner seta as long as the entire abdomen, an outer one five-eighths as long, and two minute spines at the base on the outer margin.

Egg-strings spindle-shaped, slightly swollen at the center, with bluntly rounded ends; each is as wide as the genital segment and as long as the narrowed posterior body; eggs numerous, arranged in six to eight longitudinal rows, about eighteen in each row.

First antennæ long and stout, the basal portion not much enlarged, but furnished with a dense row of stout setæ along the anterior margin. Between these antennæ on the ventral margin is a stout furca pointing backward and composed of two strong spines united by a crossbar at their base.

Second antennæ large and stout, three-jointed, terminal and basal joints the same length, the middle joint less than half as long. The terminal joint is corrugated on its ventral surface and tipped with a stout claw, as long as the joint itself and well curved, with a bristling row of spines of varying lengths around its base. Mouth-parts close behind the second antennæ; upper lip triangular, one-fifth wider than long, a rounded angle turned forward while the lateral margins are straight; the lateral angles project as rounded knobs and the posterior margin is strongly convex.

Mandibles simple, turned backward beneath the upper lip and tipped with a single straight spine. First maxilla a rounded knob armed with three plumose setæ which diminish in size from within outward. Second maxilla short and stout, turned forward and armed with a small spine on the posterior margin, and tipped with two straight spines, the inner of which is twice the size of the outer. Maxillipeds reaching forward outside the other mouth parts nearly 
to the anterior margin of the upper lip; the terminal claw large and stout, with a long curved accessory spine on the outer (distal) curve of the S. The basal joints of these maxillipeds are plainly visible behind the maxillæ and are connected across the midline by a wide sternum.

First swimming legs with a one-jointed exopod and a three-jointed endopod; second, third, and fourth legs with three-jointed rami, the spines and setæ arranged as follows: Second exopod, I-0, I-1, II7 ; endopod, $0-1,0-2$, I-3. Third exopod, I-0, I-1, $0-8$; endopod, $0-0,0-2$, II-2. Fourth exopod, I-0, I-1, $0-8$; endopod, $0-1,0-1,0-3$. The sternal plates connecting the bases of the third and fourth legs are both on the fused (third and fourth) segment, the former near the anterior margin, the latter at the center. The fifth legs are uniramose and two-jointed, the terminal joint spatulate and tipped with three spines.

Color a translucent cartilage gray, through which the snow-white uterine processes of the oviducts show prominently; the eggs are also white in younger stages of development.

Total length, $1.80 \mathrm{~mm}$. Anterior inflated portion of body, 0.85 $\mathrm{mm}$. long, $0.75 \mathrm{~mm}$. wide. Width of genital segment, $0.28 \mathrm{~mm}$. Length of egg-strings, $1 \mathrm{~mm}$.

Male.-General body form elongate, almost linear; cephalothorax spindle-shaped, strongly contracted anteriorly and posteriorly, with the lateral margins projecting. Posterior body diminishing by halves, the second and third segments nearly the same width, which is half the cephalothorax, the fourth, fifth, and genital segments half the width of the preceding two, the abdomen half the width of the genital segment and two-jointed, the basal joint twice the length of the terminal; anal laminæ linear and two-thirds the length of the last joint.

Appendages similar to those of the female with the usual sexual differences. The furca on the ventral margin between the bases of the first antennæ is considerably enlarged and its rami overlap the second antennæ. The claws at the tips of the latter appendages are also much enlarged and are bent into a half circle. The maxillipeds are three-jointed, the second joint enlarged, triangular, and armed with a row of long teeth on its inner margin; terminal claw slender, curved to fit down over the second joint, beyond the proximal end of which it projects for some distance; it also has a row of fine saw teeth which fit against those on the second joint.

First swimming legs not flattened, as in the female, but with threejointed rami like the following pairs; in the fourth endopod the two terminal joints are fused with only marginal notches to indicate the jointing; other legs as in the female. 
Total length, $1.3 \mathrm{~mm}$. Cephalothorax, $0.35 \mathrm{~mm}$. long, $0.4 \mathrm{~mm}$. wide. Free thorax, $0.37 \mathrm{~mm}$. long. Anal setæ, $0.5 \mathrm{~mm}$. long.

Color as in the female, the testes, sperm ducts, and sperm receptacles showing snow-white through the body walls.

( $\pi \dot{\alpha} \lambda \lambda \varepsilon \cup \kappa o s, \pi \tilde{a} s$ and $\lambda \varepsilon \cup \kappa o ́ s$, all white.)

This species is a very common one on the gills of the scorpion fish, nearly every fish examined being infested. The females were found fastened to the skin on the inside of the gill arches and occasionally on the filaments. The males were always fastened to the filaments.

The hold of both sexes is rather a loose one and is easily broken, and they seem to move about freely over the gills. When removed to an aquarium they fasten readily to the glass and hold on as well as to the gills. They also swim about easily and quite rapidly and may be kept alive for several days. They can not, however, crawl up out of the water like the Caligidæ, but always remain beneath the surface.

This is the first male to be described for the new genus Artacolax, and it is interesting to note some differences between it and a typical Bomolochus male. These consist chiefly in the anterior marginal furca, the huge claws at the tips of the second antennæ, and in the peculiar shape of the second joint and terminal claws of the maxillipeds.

PSEUDOEUCANTHUS UNISERIATUS, new species.

Plate 24.

Host and record of specimens.-A single lot consisting of three females with egg-strings was obtained from the mouth of the yellow jack, Caranx crysos, August 1, 1910.

Type-specimen.-Cat. No. 43510, U.S.N.M. Paratypes, Cat. No. 42256, U.S.N.M.

Female.-General body form long and narrow; cephalothorax transversely elliptical, one-sixth wider than long; frontal margin projecting as a rounded knob between the bases of the antennæ.

Carapace not reaching the lateral margins, its posterior corners prominent and rounded, overlapping the second thorax segment; no dorsal grooves; eye small and situated very far forward, almost between the bases of the antennæ. Second segment half the width of the cephalothorax and very short; third segment a little wider and considerably longer, with projecting posterior corners; fourth segment the same width as the second and as long as the third, strongly contracted posteriorly; fifth segment a little narrower than the fourth and about half as long, its lateral margins projecting angularly over the bases of the fifth legs; sixth or genital segment the same width as the fifth and two-thirds as long, its lateral margins strongly convex. 
Abdomen abruptly contracted to half the width of the genital segment, three-jointed, the joints diminishing slightly in width and considerably in length; anal laminæ narrow oblong, three times as long as wide and about the same length as the two terminal abdomen joints.

Each lamina is tipped with a large papilla carrying a long and stout seta, and with four short spines, three at the tip and one on the outer margin.

Egg-strings one-sixth longer than the entire body; eggs large and uniseriate except for a short distance near the base where there are two rows, 30 to 35 eggs in each string.

First antennæ not enlarged at the base, but with a row of wide and flattened setæ along the anterior margin; segmentation indistinct but apparently made up of five joints.

Second antennæ with a slightly enlarged terminal joint, tipped with a fleshy finger-like process and two long curved claws.

Extending along the anterior margin of the joint and to the tip of the finger process is a row of blunt teeth; the surface of the joint is also covered with corrugated ridges.

Upper lip large and shield-shaped, with prominent rounded anterior corners and a three-lobed posterior margin. Mandible directed backward and ending in a smooth, needle-like spine. First maxilla with a distinct basal portion and a prominent knob armed with three plumose setæ, the central one of which is nearly twice the length of the other two. Second maxilla with a long and swollen basal joint curved forward toward the end and tipped with two short and stout spines covered with hairs. Basal joint of the maxillipeds partly visible behind the maxillæ; second joint curved around the outside of the second maxilla and greatly elongated so that it reaches in front of even the second antennæ; terminal claw moderately bent and following the inner margin of the second joint, without accessory spines or setæ.

Exopod of first swimming leg turned forward and two-jointed, terminal joint much longer than the basal; endopod extending backward and three-jointed. Second, third, and fourth legs with threejointed rami, each joint of the exopod armed on the outer margin with short saw teeth and one or more long spines; arrangement of the spines and setæ as follows: Second exopod, I-0, I-0, II-3; endopod, $0-1,0-2$, II -3 . Third exopod, I-0, I-0, III-3; endopod, $0-1,0-1$, I-3. Fourth exopod, I-0, I-0, III-3; endopod, $0-1,0-1, \mathrm{I}-2$. Fifth legs uniramose but wider and longer than any of the others, each tipped with three spines and carrying a fourth on the outer margin. 
Uterine processes of the oviducts filling the posterior fourth of the cephalothorax and the second, third, and fourth segments, sending a branch out into the base of each of the swimming legs.

Color a dark gray, the cephalothorax nearly transparent, the uterine processes snow-white.

Total length, $1.25 \mathrm{~mm}$. Cephalothorax, $0.5 \mathrm{~mm}$. long, $0.45 \mathrm{~mm}$. wide. Free thorax, $0.5 \mathrm{~mm}$. long, $0.25 \mathrm{~mm}$. wide. Egg-strings, 1.5 $\mathrm{mm}$. long, $0.1 \mathrm{~mm}$. wide.

(uniseriatus, arranged in a single series, alluding to the eggs.)

The present genus was created by Brian in 1906 for some parasites which had been obtained from the eye of "Clupea alosa." The naming of the genus was unfortunate in every particular. The name Eucanthus given by Claus had been preoccupied many years before for a genus of coleoptera and hence can not stand. We thus have a Pseudoeucanthus but no Eucanthus.

Again, Claus's genus was distinguished from Bomolochus by the presence of maxillary hooks and by the normal position of the maxillipeds behind the other mouth parts. Brian's genus shows neither of these peculiarities but has the mouth parts like those of Bomolochus, and might far better have been called Pseudobomolochus. Indeed, while it is easily distinguished from Eucanthus (Anchistrotos), what it really demands is a better separation from Bomolochus. This may be stated as follows: First antennæ neither enlarged nor curved at the base and destitute of tactile setæ; maxillipeds without plumose setæ or accessory spines; exopod segments of the second, third, and fourth legs fused and only the terminal joint armed with plumose setæ; single ramus of the fifth legs longer and wider than any of the others; each anal lamina tipped with a single-jointed seta and small spines; genital segment very short and carrying rudimentary sixth legs; eggs very large, in two rows only or even mostly uniseriate, forming strings similar to those in the Caligidæ and unlike the rest of the Ergasilidæ.

These specimens, obtained and examined alive, enable us to decide all those points in Brian's original description which needed confirmation or correction. ${ }^{1}$

1. There are four free segments in front of the genital segment as in Bomolochus. The first of these, really the second thorax segment, is very short and narrower than the third segment. This segment is not indicated in Brian's figures or description.

2. This genus possesses first maxillæ similar to those in the other genera of the family.

3. The specimen figured by Brian as a "male(?)" was really a female without egg-strings. 
T AENIACANTHUS FLAGELLANS, new species.

Plate 25, figs. 54-61.

Host and record of specimens.-Six females with egg-strings were obtained from the gill cavity of the hammer-head shark, Sphyrna zygæna, at different times, two being the largest number from any single shark.

Type-specimen.-Cat. No. 43517, U.S.N.M. Paratypes, Cat. No. 42261, U.S.N.M.

Female.-General body form elongate and narrow, especially posteriorly; cephalothorax turned over ventrally so as to stand at right angles to the rest of the body axis; ventral surface of this cephalothorax prolonged into a sucking disk which protrudes beyond all the mouth parts and is surrounded by a membranous edge, similar to that on the sucking disks of Argulus.

The first antennæ lie along the anterior portion of this edge while the first legs curve around the posterior portion and both no doubt aid in attaching and releasing the disk.

Cephalothorax triangular in dorsal outline, with rounded corners, considerably wider than the second (first free) segment, and entirely covering the antennæ, mouth parts, and first legs. Second to fifth segments about the same length but diminishing regularly in width, and showing successively larger portions of the swimming legs, until the whole of the fifth pair appears in dorsal view. Genital segment the same width as the fifth segment and nearly twice as long, tapering posteriorly.

Abdomen composed of four segments, diminishing regularly in size, except that the third one is a little shorter than the last. Anal laminæ narrow, two-thirds the length of the last segment, each tipped with two setæ of which the inner one is half as long again as the outer. Egg-cases attached to the anterior end of the genital segment on the dorsal surface, their bases covered by the rudimentary sixth legs. Each case is about the same diameter as the abdomen and reaches to the center or even the tips of the longest anal setæ; eggs numerous, arranged in six or seven longitudinal rows, 18 or 20 eggs in a row.

Basal portion of first antennæ not much enlarged, indistinctly divided into three parts, with a fringe of large flattened setæ along the anterior margin; terminal portion made up of three distinct segments, heavily armed with setæ.

Second antennæ three-jointed and tipped with three long curved claws, the ventral surface of the terminal joint being corrugated.

Mouth parts close to the second antennæ; upper lip two and a half times as wide as long, the two anterior margins slightly concave, the posterior one convex. Mandibles three-jointed, the two distal joints bent backward at an angle with the basal joint; the terminal joint a simple straight spine. First maxilla armed with three setæ 
of about the same length. Second maxilla tipped with two spines, the posterior one twice the size of the anterior. Maxillipeds with the terminal joint bent back against the basal and tipped with two spines, the outer (posterior) of which is twice the size of the inner. Behind the bases of the maxillipeds, on either side of the midline and close to it, is a short accessory spine.

Each ramus of the first legs is two-jointed, those of the second, third, and fourth legs three-jointed, with the arrangement of the spines and setæ as follows: Second exopod, I-0, I-1, II-7; endopod, $0-1,0-2$, II-4. Third exopod, I-0, I-1, II-6; endopod, $0-1$, I-2, II-3. Fourth exopod, I-0, I-1, I-6; endopod, 0-1, I-2, II-3. Fifth legs two-jointed, the terminal joint enlarged and tipped with four spines.

Ovaries in the lateral portions of the cephalothorax; oviducts extending back along the lateral margins of the free thorax segments, sending out short and stout uterine processes into each segment.

Color a clear cartilage gray, the ovaries and processes white.

Total length, $3 \mathrm{~mm}$. Cephalothorax, $0.70 \mathrm{~mm}$. long, $0.98 \mathrm{~mm}$. wide. Free thorax, $1 \mathrm{~mm}$. long. Egg-cases, $1.5 \mathrm{~mm}$. long.

(flagellans, flagellating or lashing, in allusion to the lashing motions when disturbed.)

This genus was established by Sumpf (1871) upon some specimens obtained from the gills of Carcharias (Carcharhinus) lamia. A new species was added by the present author in 1910 obtained from the vent of the bonnet-head shark, Sphyrna tiburo. The present is a third species from the gills of the hammer-head, and having been studied alive some notes can be added on the habits of the genus. All the specimens were found attached to the skin of the gill partitions just outside of the filaments. When detached and placed in an aquarium they swim about as freely as pelagic forms and may be kept alive for several days. The ventral disk protrudes like a sucker's mouth and is the chief organ of attachment, thus emphasizing one of the chief differences between the subfamilies of the Ergasilidæ. In the Ergasilinæ there is no ventral disk and attachment is entirely by means of the second antennæ; in the Bomolochinæ there is such a disk, but the stout claws on the maxillipeds show that they play an important part in attachment; here in the Tæniacanthinæ the ventral disk is fully developed, and is the only organ of attachment, the antennæ and maxillipeds having degenerated beyond practical use. The parasites catch on and let go with great ease and celerity and adhere to glass as readily as to the fish's gills. When thus attached the long thorax and abdomen are lashed about actively, especially upon irritation, and this peculiar habit is sure to attract attention to the copepod. When the gills are placed in water the parasites leave them quickly and swim about, usually without returning to them again. 


\section{Family CALIGIDÆ.}

\section{CALIGUS PRODUCTUS Dana.}

Caligus productus DANA, 1854, p. 1354, pl. 94, fig. 4.

Host and record of specimens.-This species was originally described by Dana from specimens obtained from the common dolphin, Coryphæna hippurus, and from trigger fishes, Balistes, in the West Indies. It was afterward noted by Steenstrup and Lütken (1861, p. 357) as taken from the inside of the operculum of the barracuda, Sphyræna barracuda, and by Krøyer (1863, p. 64) as found on the same Coryphrna as Dana's specimens. In both of these instances the locality given was the Danish West Indies.

\section{CALIGUS BALIST $Æ$ Steenstrup and Luitken.}

Caligus balistæ Steenstrup and Lütken, 1861, p. 356, pl. 1, fig. 1.

Host and record of specimens.-This species was originally obtained from the mouth and fins of a West Indian Balistes, probably B. vetula, and included both sexes. It has not been found by any subsequent investigators.

CALIGUS ISONYX Steenstrup and Lütken.

Caligus isonyx Steenstrup and Lütken, 1861, p. 358, pl. 3, fig. 5.

Host and record of specimens. - This species is based on a single female taken from the gills of a great barracuda, Sphyræna barracuda, in the West Indies. No other specimen has ever been obtained.

\section{CALIGUS HAEMLONIS Krøyer.}

Caligus hæmulonis KRфyer, 1863, p. 48, pl. 4, fig. $3 a-d$.

Host and record of specimens.-Three specimens, two females and a male, of this species were taken from the gills of the yellow grunt, Hæmulon sciurus (H. elegans Cuvier), in the Danish West Indies. No other specimens have ever been obtained,

\section{CALIGUS TENAX Heller.}

Plate 26; plate 29, figs. 99-101.

Caligus tenax Heller, 1865, p. 172, pl. 15, fig. 3.

Host and record of specimens.-The original type-specimens were obtained from the gills of the horse crevalle, Caranx hippos (C. carangus of Heller), in Brazil. These included females only. Later (1898) Bassett-Smith reported both sexes from various species of Caranx in the Indian Ocean. Both sexes were also obtained from the gills of Caranx crysos July 12, and from Caranx hippos July 29, 1910, and have received Cat. Nos. 42301 and 42341, U.S.N.M.

Female.-General body form long and stout; carapace ovate, onesixth wider than long, strongly contracted anteriorly; frontal plates prominent; lunules semicircular, projecting half their width; frontal 
margin straight, deeply incised at the center; lateral areas very wide; lateral lobes also wide and short, curved strongly inward and almost squarely truncated at the ends; median lobe a little more than onethird the width of the carapace, with projecting corners which overlap the lateral lobes, and an emarginate posterior border. Eye minute, one-third the length of the carapace behind the anterior margin. Free segment short, two-sevenths the width of the carapace; genital segment acorn-shaped, three-fourths the length and half the width of the carapace, with wide and bluntly rounded posterior lobes.

Abdomen one-jointed, three-sevenths of the width and a little more than half the length of the genital segment; anal laminæ minute, widely separated, each tipped with four short setæ.

Egg-tubes three-fourths the width of the abdomen and a little more than half the length of the body.

Terminal joints of the first antennæ very slender, much longer than the basal joints, ten times as long as wide. Second antennæ rather slender, with a long terminal claw bent at a right angle near the tip. Maxillary hooks short and nearly straight, with a strongly inflated base; first maxillæ short and triangular, with a small secondary spine near the center of the inner margin. Maxillipeds with a stout terminal claw fully as long as the moderately inflated basal joint and strongly curved. Furca with an exceptionally broad, three-lobed base and the short rami curved so as to form together a half circle. First swimming legs with a very rudimentary one-jointed endopod, and with short plumose setæ on the terminal joint of the exopod; second legs with medium-sized spines on the exopod, whose second joint carries an exceptionally wide rowing seta; rami of third legs close together, the spine on the exopod long and stout and bent into a half circle; fourth legs four-jointed with five spines subequal in length.

Cement glands situated far forward in the genital segment and inclined outward, the divisions of the glandular portion showing like a string of beads through their center.

Color a clear cartilage-gray, very translucent except toward the margin, with ten small circular pigment spots of dark bluish-purple on the dorsal surface of the carapace, arranged in pairs.

Total length, $4 \mathrm{~mm}$. Carapace, $1.75 \mathrm{~mm}$. long, $2 \mathrm{~mm}$. wide. Genital segment, $1.3 \mathrm{~mm}$. long, $1 \mathrm{~mm}$. wide. Abdomen, $0.8 \mathrm{~mm}$. long, $0.5 \mathrm{~mm}$. wide. Egg-strings $2.25 \mathrm{~mm}$. long, $0.33 \mathrm{~mm}$. wide.

Male.-Carapace in all respects similar to that of the female, but proportionally larger; free segment longer and contracted into a neck anteriorly and posteriorly; genital segment barrel-shaped, with moderately curved sides and small posterior lobes closely approximated to the sides of the abdomen, which latter is almost as wide as

$69077^{\circ}$-Proc.N.M.vol.44-13-14 
the genital segment and indistinctly two-jointed, the basal joint much the shorter; anal laminæ small and circular, each tipped with three long setæ and a shorter one on the lateral margin.

Terminal joints of the first antennæ even longer and more slender than in the female.

Second antennæ with a much longer second joint and a shorter terminal claw, curved into a horseshoe shape. Maxillary hooks longer and more slender but straight; other appendages like those of the female except that both the fifth and sixth legs are present on the genital segment, the former on the lateral margins opposite the sperm receptacles, the latter forming the posterior lobes.

Color as in the female.

Total length, $2.85 \mathrm{~mm}$. Carapace, $1.6 \mathrm{~mm}$. long, $1.7 \mathrm{~mm}$. wide. Genital segment, $0.65 \mathrm{~mm}$. long, $0.45 \mathrm{~mm}$. wide.

Heller's description of the female of this species was good and such figures as he presented were excellent, but both were made from preserved material alone and lacked many details. Bassett-Smith's description of the male is far from satisfactory and his single figure gives no details whatever.

The present specimens having been obtained alive and kept for several days, an attempt has been made to give a complete description from them, particularly with regard to color and proportions. Among these specimens were two chalimus larvæ; in the smaller one only the first thorax segment was fused with the carapace and the endopod of the first legs was as large as the exopod. In the larger one the first two thorax segments were fused with the carapace and the first endopod had become very rudimentary. Both sexes swim about in an aquarium almost constantly and are fully as lively as $C$. rapax. The species is not a common one, for among the large number of jacks examined during the season only two were found infested with this parasite. One of these, however, yielded a dozen specimens, which was an exceptionally large number.

CALIGUS IRRITANS Heller.

Plate 25, fig. 62 ; plate 27.

Caligus irritans Heller, 1865, p. 177, pl. 15, figs. 7 and 8.

Host and record of specimens.-A male and female of this species were obtained from the gills of a large (12 pounds) red snapper, Neomænis aya, on July 22, 1910. They have been given Cat. No. 42262, U.S.N.M.

Female.-General body form long and stout; carapace ovate, longer than wide and one-fourth shorter than the rest of the body; frontal plates prominent, lunules enormous and circular, separated by a distance equal to their own diameter; lateral areas narrow, lateral lobes curved inward at their tips and bluntly rounded; 
median lobe half the diameter of the carapace, with a nearly straight posterior margin on a level with the tips of the lateral lobes.

Free segment short, about one-fourth the width of the carapace; genital segment shaped like a broad acorn with a slightly reentrant posterior margin, three-fourths the size of the carapace, without lobes or fifth legs.

Abdomen two-jointed, basal joint considerably the longer; onethird-the width and five-sevenths the length of the genital segment; anal laminæ short and wide, each tipped with five setæ.

Of the appendages the maxillary hooks have an inflated circular base and a long and strongly curved ramus. First maxillæ slender and extending considerably beyond the tip of the mouth; rudimentary endopods present, each tipped with a single spine.

Mouth tube very short and wide, in fact almost circular in ventral outline. Terminal claw of maxillipeds less than two-fifths of the length of the basal joint, stout and strongly curved, with a spine on its inner margin. Furca long and narrow, contracted at the base of the rami, which are slender, bluntly rounded and curved like parenthesis marks. First swimming legs short and stout, with two spines on the ventral surface of the basal joint at the distal end and one on the posterior margin; rami of second legs equal in length, the spines on the exopod slender and weak; rami of third legs well separated, short and wide; fourth legs three-jointed with five subequal spines. Cement glands divergent, with their bases close to the midline, the beaded portion narrow and extending through the center of the gland.

Color a uniform cartilage-gray without pigment marks of any sort. Total length, $4.16 \mathrm{~mm}$. Carapace, $1.83 \mathrm{~mm}$. long, $1.6 \mathrm{~mm}$. wide. Genital segment, $1.25 \mathrm{~mm}$. long, $1 \mathrm{~mm}$. wide. Abdomen, $0.92 \mathrm{~mm}$. long, $0.35 \mathrm{~mm}$. wide.

Male.-Carapace similar in all respects to that of the female, but proportionally larger, the medium lobe projecting a little behind the lateral lobes; genital segment barrel-shaped, with strongly convex sides and straight anterior and posterior margins; both the fifth and the sixth legs present, the former just behind the center of the lateral margin and tipped with a single spine, the latter farther back and more prominent, tipped with two spines.

Basal abdomen joint considerably shorter than the terminal; anal laminæ long and wide, each tipped with four setæ.

Second antennæ with a swollen and corrugated basal joint and an exceptionally short and stubby terminal claw; maxillary hooks enlarged so that they are longer and stouter than the entire second antennæ. Maxillipeds with a strongly swollen basal joint armed with five large saw teeth on its inner margin, against which the terminal claw shuts when closed. 
Furca much narrower than in the female and somewhat different in shape. (See fig. 72.)

Color like that of the female.

Total length, $3.5 \mathrm{~mm}$. Carapace, $2 \mathrm{~mm}$. long, $1.5 \mathrm{~mm}$. wide. Genital segment, $0.57 \mathrm{~mm}$. long, $0.48 \mathrm{~mm}$. wide.

This species was originally described by Heller from specimens obtained on the gills of a Serranus species from Brazil and has not been seen since. The present specimens differ in several of the minor details but are undoubtedly the same species. They are here redescribed to confirm Heller's species, to show the variations in minor details, and to emphasize the distinguishing characters. These latter are to be found in the general body proportions, the exceptionally large lunules, the very short and almost circular mouth tube, and in the male the stubby claws on the second antennæ, the greatly enlarged maxillary hook and the stout, toothed basal joints of the maxillipeds.

The species is very rare, only the single pair being obtained during the entire season.

\section{CALIGUS ROBUSTUS Bassett-Smith.}

Plate 28.

Caligus robustus BASSETt-Sмith, 1898, p. 361, pl. 11, figs. 1-2.

Host and record of specimens.-A male and female were obtained from the gills of the red-mouthed grunt, Bathystoma rimator, July 14, 1910, and have received Cat. No. 42260, U.S.N.M. Two much larger females were afterwards found upon the gills of the crevalle, Caranx crysos, and were given Cat. No. 42268, U.S.N.M.

Female.-General body form short and stout; carapace ovate, as wide as long; frontal plates narrow and not prominent; lunules small, circular, and projecting moderately; lateral areas very wide and terminating in wide and blunt posterior lobes; median lobe threesevenths the entire width and reaching but little behind the lateral lobes; posterior sinuses shallow with parallel sides.

Eye medium-sized and placed far forward, one-fifth the length of the carapace behind the anterior margin.

Free segment nearly one-third the width of the carapace, strongly contracted anteriorly and posteriorly. Genital segment broad acorn-shaped, a little wider than long, with the lateral margins strongly convex, the posterior margin nearly straight, the corners evenly rounded without lobes, and the fifth legs visible just outside the bases of the egg strings. Abdomen less than one-fourth the width of the genital segment and considerably shorter, two-jointed, basal joint twice the length of the terminal.

Anal laminæ large and inclined toward each other, each tipped with three setæ of equal length and two short spines on the outer 
margin. Egg-strings half the entire length, each one-third wider than the abdomen and containing 20 to 25 eggs.

First antennæ short, not reaching the lateral margin of the carapace; second pair with a stout basal joint but a weak and slender terminal claw. Maxillary hooks minute, with an inflated circular base and a very short tip; first maxillæ long, wide, and bluntly rounded at the tip, projecting well beyond the mouth tube, which is short and wide. Maxillipeds with a stout basal joint bearing an enormous broad spine on its inner margin and a much smaller secondary one at its base. The point of the terminal claw, which is stout and less than half the length of the basal joint, shuts in between the two spines. Furca stout, contracted at the center and enlarged at either end, the rami broadly laminate, bluntly rounded, and nearly straight.

Exopod of the second swimming legs shorter than the endopod and armed with very long and acuminate spines; rami of third legs well separated, exopod long and narrow with a medium-sized bluntly pointed spine; fourth legs stout, the three terminal joints nearly as wide as the basal, the five spines subequal; fifth legs each tipped with two spines.

Color a uniform white, without pigment markings of any sort.

Total length, $4.2 \mathrm{~mm}$. Carapace, $2 \mathrm{~mm}$. long, $2 \mathrm{~mm}$. wide. Genital segment, $1.1 \mathrm{~mm}$. long, $1.3 \mathrm{~mm}$. wide. Abdomen, $1 \mathrm{~mm}$. long, $0.27 \mathrm{~mm}$. wide. Egg-strings, $2 \mathrm{~mm}$. long. The females from Caranx crysos had a total length of $7 \mathrm{~mm}$., with the other measurements in proportion.

Male.-Carapace and free segment similar to those of the female, the former a little more than half the entire length. Genital segment less than a third the width of the carapace, barrel-shaped, with strongly convex sides and short posterior lobes; fifth and sixth legs both present, the former just behind the center of the lateral margins, the latter forming the posterior lobes.

Abdomen two-jointed but with the terminal joint three times the length of the basal; anal laminæ large and inclined toward each other, each tipped with three long setæ and a fourth shorter one on the outer margin. Appendages like those of the female without even the customary differences in the second antennæ, maxillary hooks, and maxillipeds.

Color like the female.

Total length, $2.64 \mathrm{~mm}$. Carapace, $1.35 \mathrm{~mm}$. long, $1.36 \mathrm{~mm}$. wide. Genital segment, $0.43 \mathrm{~mm}$. long and the same width.

Bassett-Smith's original specimens were obtained from the operculum or gill rays of various species of Caranx and Thynnus from the Indian Ocean. The specimens from the red-mouthed grunt are much smaller than his but there can be no doubt they are the same 
species, while the two from the jack are fully as large as his. As Bassett-Smith says, the species somewhat resembles Caligus irritans Heller, but it shows these differences. The genital segment in both sexes is much shorter and wider, the abdomen is narrower, the maxillary hooks are not enlarged in the male, the maxillipeds are alike in the two sexes and very different from either sex in irritans, the furca is much stouter and often contracted at the center, and the details of the swimming legs are quite different, especially the fourth pair.

In the two large females from the jack the contents of the digestive tube showed dark bluish-black by transmitted light, and the ventral surface of the genital segment was covered with an irregular pattern of fine bluish-purple lines.

As the species has been seen only by Bassett-Smith, and as the present locality is far removed from the Indian Ocean, it has been deemed wise to give a new description and figures.

CALIGUS ATROMACULATUS, new species.

Plate 29, figs. 92-98.

Host and record of specimens.-Two females, both with egg-strings, belonging to this tiny species were found fastened to the gill filaments of the doctor fish, Teuthis hepatus.

Type-specimen.-Cat. No. 42348, U.S.N.M.

Female.-General body form short and stout; carapace about half the entire length, a little longer than wide; frontal plates projecting prominently; lunules large, circular, and close to the mid-line; frontal margin straight without any median incision; cross-bar of the $\mathrm{H}$ groove curved forward so that its center is close behind the eye; lateral areas only one-seventh the width of the thoracic area, lateral lobes pointed and curved inward; posterior sinuses narrow and deep; median lobe almost squarely truncated posteriorly and projecting but little behind the lateral lobes.

Eye large and placed about one-fourth of the length of the carapace behind its anterior margin.

Free segment short and contracted into a waist anteriorly; genital segment ovate, one-third the entire length, with evenly rounded sides and corners and a squarely truncated posterior margin, without lobes or fifth legs.

Abdomen minute, one-fourth the length and width of the genital segment; anal laminæ spherical and well separated, each tipped with five setæ, the three middle ones three times the length of the other two.

Egg-strings very wide and short, each nearly half the width and the same length as the genital segment and containing a dozen eggs.

First antennæ short and slender, the tips just reaching the lateral margins of the carapace; second pair stout, the terminal claw much longer than the basal joint and bent near its tip; maxillary hooks 
three-quarters as large as the terminal claws of the second antennæ, slender, and curved but slightly; maxillæ reaching well beyond the end of the short and wide mouth tube, slender, with an enlarged and bluntly rounded tip; maxillipeds small, the terminal claw weak and only half the length of the basal joint. Furca proportionally large, the basal part subquadrilateral with the sides slightly reentrant, the rami one-half longer than the base, nearly parallel, with flattened spatulate tips.

Claws on the exopods of the second legs long and slender; rami of the third legs small and well separated; fourth legs (including their spines) reaching nearly to the posterior margin of the genital segment, but slender, with a short spine on the outer margin of the basal joint near its distal end, a long terminal spine at the tips of the second and third joints and two on the terminal joint, of which the inner is twice the length of the outer.

Color a clear cartilage gray, thickly covered on the dorsal surface with small spots of jet black; these spots are circular in outline and are thickest along the midline where they extend the entire length of the body.

Total length, $2.05 \mathrm{~mm}$. Carapace, $1.1 \mathrm{~mm}$. long, $0.95 \mathrm{~mm}$. wide. Genital segment, $0.65 \mathrm{~mm}$. long and the same width. Abdomen, $0.15 \mathrm{~mm}$. long. Egg-strings, $0.8 \mathrm{~mm}$. long.

(atromaculatus, ater, black, and maculatus, spotted.)

This tiny species proved to be very sluggish when transferred to an aquarium and did not swim about at all, simply lying on its back and moving its appendages feebly. Its distinguishing characters are the black spots on the dorsal surface, the large circular lunules, the spatulate tips of the first maxillæ, the long and club-shaped rami of the furca, and the weak and slender fourth legs.

CALIGUS AFURCATUS, new species.

Plate 30, figs. 102-106; plate 32, figs. 136-138.

Host and record of specimens.-Three females with egg-strings were found fastened to the sides of the filaments, in the spaces between adjacent filaments, on the gills of an 8-pound green parrot fish, Sparisoma viride, in company with the following species.

Type-specimen.-Cat. No. 43518, U.S.N.M. Paratypes, Cat. No. 42259, U.S.N.M.

Female.-General body form short and stout; carapace ovate, oneeighth longer than wide, narrowed anteriorly; frontal plates narrow and not prominent; lunules small, widely separated, circular, and not projecting; eye small; lateral areas narrow, lateral lobes bluntly rounded and inclined inward; median lobe half the entire width and projecting for half its length behind the lateral lobes; posterior sinuses narrow and inclined outward; crossbar of the $\mathrm{H}$ grooves convex 
anteriorly, crossing the midline at the center of the carapace. Free segment short, one-fourth the width of the carapace and swollen through the bases of the legs. Genital segment ovate, with strongly convex sides and short, broad posterior lobes.

Abdomen minute, triangular, one-jointed; anal laminæ long and narrow, each tipped with four tiny spines.

Egg-strings three-fourths as long as the entire body, each containing about 30 eggs.

First antennæ small, the joints about the same length; second pair large, with a long and slender terminal claw bent into a half circle. Maxillary hooks so minute as to be scarcely visible; first maxillæ reduced to mere pimples at the sides of the mouth tube, short and bluntly rounded but still retaining the rudimentary exopod tipped with two spines. Maxillipeds long and slender, basal joint three and a half times as long as wide, terminal claw stout and acuminate, shorter than the basal joint and not much curved. First swimming legs also long and slender, the terminal joint with only two claws at the end and three weak setæ on the posterior border. Terminal joint of the exopod of the second legs long and wide, spine on the basal joint narrow and acuminate, spines on the two terminal joints exceptionally small and short. Rami of third legs well separated, claw on the exopod short, stout, and straight, the joints longer than usual and well armed with setæ and spines. Fourth legs threejointed, the two terminal of the usual four joints being fused; basal joint a little longer than the rest of the leg and carrying a good-sized spine on its outer margin near the distal end; the inner terminal spine about twice the length of the other four, which are subequal.

Cement glands short and stout and inclined away from the midline with their convex sides toward it.

Color a dark cartilage-gray, ornamented on the dorsal surface of the entire body, and on the ventral surface of the abdomen, with an intricate network of fine lines of dark bluish-purple.

Total length, $2.32 \mathrm{~mm}$. Carapace, $1.4 \mathrm{~mm}$. long, $1.25 \mathrm{~mm}$. wide. Genital segment, $0.75 \mathrm{~mm}$. long, $0.65 \mathrm{~mm}$. wide. Egg-strings, 1.9 mm. long.

(afurcatus, a, not, and furcatus, provided with a furca.)

This species bears some resemblance to $C$. balistæe, but may be easily distinguished by the much shorter abdomen, by the absence of a furca, by the degenerate form of the maxillary hooks and first maxillæ, and by the fact that the fourth legs have five spines instead of only four. The only other Caligus species which possess as short an abdomen are Krøyer's $C$. abbreviatus and the species which here follows, C. enormis.

From the former the present species may be distinguished by the absence of a furca and the fifth legs, and by the presence of six spines 
on the fourth legs instead of four; from the latter it may be distinguished at once by the relative size and shape of the carapace and abdomen.

CALIGUS ENORMIS, new species.

\section{Plate 31.}

Host and record of specimens.-A dozen specimens, including both sexes, were found clinging to the inside of the gill filaments of the same 8-pound green parrot fish, Sparisoma viride, that served as the host of the preceding species.

Type-specimen.-A female, Cat. No. 43593, U.S.N.M. Paratypes, Cat. No, 42263, U.S.N.M.

Female.-General body form elongate and narrow; carapace and genital segment approximately the same size, each of them being constricted where it joins the fourth (free) segment, thus giving the body somewhat the shape of a dumb-bell. Carapace only threesevenths of the entire length, elliptical, one-third longer than wide; frontal plates narrow and prominent; lunules reduced to narrow lines with scarcely any curve, close together, with no incision in the short frontal margin between them. Eye large and placed well forward. Lateral areas wide, the posterior lobes turned slightly outward; median lobe twice the width of the lateral lobes and reaching more than half its length behind them; posterior sinuses broad and shallow.

Free segment one-third the width of the carapace, with convex lateral margins. Genital segment elliptical, the same length as the carapace but a little narrower, with rounded corners and nearly straight sides.

Abdomen reduced to a comparatively minute protuberance at the posterior end of the genital segment, triangular and one-jointed; each anal lamina as large as its half of the abdomen and tipped with three short setæ and a fourth one on the outer margin.

Egg-strings exceptionally short and wide, similar to those found in many Dichelestiids, each half the width of the genital segment and not quite equaling it in length; only six or seven eggs in each string.

First antennæ short and stout, not reaching more than halfway to he lateral margins, the two joints about the same length and well armed. Second pair with a slender terminal claw, slightly bent near the tip. Maxillary hooks and first maxillæ reduced to tiny spines that can hardly be detected; second maxillæ exceptionally large and stout, the two joints about the same size, the terminal claws short and stout. Maxillipeds with a swollen basal joint and a strong terminal claw carrying an accessory spine on its inner margin toward the tip. Furca entirely lacking. First swimming legs rudimentary, made up of three short and wide joints of about the same size, the terminal one with four claws at the tip but no setæ on the posterior margin. Exopods of second pair extending outward in line with the basal joint 
and at right angles to the body axis, and appearing in dorsal view just behind the posterior lobes of the carapace; the endopod is carried at right angles to the exopod, or parallel to the body axis. Third legs reduced far more than is usual in the genus, the spine on the exopod straight instead of curved, the terminal joint with four spines but only a single seta; the endopod contains but one partial joint, which is fused to the basal plate. Fourth legs stout and of the usual pattern, three-jointed, the inner terminal spine two and a half times as long as the other four which are about equal. Fifth legs present just in front of the posterior corners of the genital segment, the endopod represented by a single spine, the exopod by a papilla tipped with two spines.

Color a light cartilage-gray, exceptionally translucent and ornamented on the dorsal surface of the carapace with a few scattered and irregular spots of purple pigment.

Total length, $2.15 \mathrm{~mm}$. Carapace, $0.95 \mathrm{~mm}$. long, $0.75 \mathrm{~mm}$. wide. Genital segment, $0.9 \mathrm{~mm}$. long, $0.6 \mathrm{~mm}$. wide. Egg-strings, $0.8 \mathrm{~mm}$. long, $0.28 \mathrm{~mm}$. wide.

Male.-General form narrow and elongate; carapace exactly like that of the female, but the posterior body much narrower. Lunules larger and semicircular; eye farther back in the carapace; posterior sinuses even shallower than in the female.

Genital segment barrel-shaped, considerably less than half the width of the carapace and just about half the length.

Abdomen two-thirds as wide and three-fifths as long as the genital segment; anal laminæ large, each tipped with three medium-sized setæ and two short spines on the outer margin.

Appendages like those of the female, with the following exceptions: The first antennæ reach fully to the lateral margins of the carapace; the terminal claw on the second pair has the usual accessory spines and corrugated surfaces found in the male sex; the maxillary hook is enormously enlarged, so that it is larger than the claw on the second antenna; the basal joint of the maxilliped is much swollen, and is armed with a stout spine on its inner margin, which interlocks with the tip of the terminal claw; the accessory spine on the latter claw is close to the base instead of near the tip.

Color as in the female.

Total length, $1.6 \mathrm{~mm}$. Carapace, $0.8 \mathrm{~mm}$. long, $0.6 \mathrm{~mm}$. wide. Genital segment, $0.4 \mathrm{~mm}$. long, $0.25 \mathrm{~mm}$. wide.

(enormis, irregular, unusual.)

This little Caligus is irregular in many respects, such as the extreme reduction of the maxillary hooks in the female and their enormous enlargement in the male; in the almost complete obliteration of the lunules in the female; in the great reduction of the maxillæ in both sexes; in the absence of a furca; in the lack of plumose setæ on the first 
legs; in the arrangement of the endopod and exopod of the second legs; in the fusion of the endopod of the third legs to the basal plate; in the practical disappearance of the abdomen in the female; and in the peculiar size and shape of the egg-strings.

Taken separately, none of these modifications possesses very much systematic value, but collectively they serve to distinguish the new species from all that have previously been described.

In its general make-up and in its habits it is a typical Caligus, and although the species is so small the enlargement of the eggs indicates that the nauplii on hatching are fully the size of those from larger species. This increase in size and consequent ability must compensate in some way for the paucity in the number of eggs.

\section{CALIGUS SUFFUSCUS, new species.}

Plate 30, figs. 107-115.

Host and record of specimens.-A couple of females were taken from the mouth of the blue parrot fish, Scarus cœruleus, June 30, 1910.

\section{Type-specimen.-Cat. No. 42267, U.S.N.M.}

Female.-General body form short and plump; carapace definitely more than half the entire length, one-fourth longer than wide. Frontal plates not prominent; anterior margin nearly straight, with an incision at the center; lunules of medium size and widely separated, just reaching the anterior margin. Eye relatively large and situated far forward; crossbar of the $\mathrm{H}$ about in the center of the carapace; lateral areas very narrow, less than one-fourth the width of the thoracic area; lateral lobes obliquely truncated posteriorly; posterior sinuses shallow; median lobe considerably more than half the entire width and projecting far behind the lateral lobes. Free segment one-third the width of the carapace, short and strongly contracted anteriorly and posteriorly. Genital segment one-third the entire length, ovate in outline, squarely truncated posteriorly; corners smoothly rounded and without lobes; fifth legs visible.

Abdomen minute, elliptical, about one-fourth the width and length of the genital segment; anal laminæ widely separated and divergent, each tipped with three long setæ and three short spines on the outer margin. Egg-tubes unknown.

First antennæ short and plump, not reaching the level of the lateral margin; second pair fairly stout, the terminal claw strongly curved, the basal joint reinforced by a long and sharp spine just behind its insertion. Mouth tube short and stout, first maxilla long and slender, reaching well beyond the tip of the mouth tube. Maxilliped with a swollen basal joint and a stout terminal claw, threequarters as long as the basal joint and strongly curved, with an accessory spine on its inner margin near the center. Furca large 
and stout, the basal portion nearly rectangular, the rami broad, slightly divergent, of the same length as the basal portion, and bluntly rounded.

First and second swimming legs of the usual pattern; rami of the third pair small and well separated, but rendered prominent by the wide gap between the posterior lobes of the carapace and the genital segment. Fourth legs reaching a little beyond the center of the genital segment, the basal joint as long as the three terminal joints; the latter with five spines, all the same size except the middle terminal one, which is twice the length of the others.

Color yellowish-white, covered on the dorsal surface with sparsely scattered circular spots of brown pigment.

Total length, $2.35 \mathrm{~mm}$. Carapace, $1.25 \mathrm{~mm}$. long, $1.05 \mathrm{~mm}$. wide. Genital segment, $0.75 \mathrm{~mm}$. long, $0.63 \mathrm{~mm}$. wide. Abdomen, $0.2 \mathrm{~mm}$. long, $0.15 \mathrm{~mm}$. wide.

(suffuscus, sub and fuscus, somewhat brownish or dusky, alluding to the spots on the dorsal surface.)

In its general proportions this species resembles $C$. abbreviatus Krøyer, but the lunules and first antennæ are proportionally much longer, the carapace is not contracted anteriorly, the median lobe projects far behind the lateral lobes, the genital segment is onefourth longer than wide, instead of one-half wider than long, and the abdomen projects for its entire length behind the genital segment. These characters, together with many differences in the appendages, are sufficient to distinguish the species and establish its validity.

CALIGUS MONACANTHI Køøer.

Caligus monacanthi Krøуer, 1863, p. 59, pl. 3, fig. $2 a-e$.

Host and record of specimens.-Krøyer obtained a single male, which he referred to this species, from the skin of a Monacanthus (probably M. hispidus, the file fish) in the West Indies.

The present author has given elsewhere ${ }^{1}$ reasons for believing that this was really a young female $C$. productus. It is impossible to be absolutely certain without further material, and so the record is here repeated.

\section{LEPEOPHTHEIRUS COSSYPHI Krøyer.}

Lepeophtheirus cossyphi KrфYeR, 18s63, p. 115, pl. 7, fig. 6a-e.

Host and record of specimens.-A single female was taken by Krøyer from the gills of "Cossyphus bodjanus" (the Spanish lady fish, Harpe rufa) in the West Indies, but this single specimen presents sufficient distinguishing characters to establish the validity of the species.

Two other species of Lepeophtheirus have been recorded from fish that are common in the West Indies, and from which they are likely 
to be obtained in the future. These are L. dissimulatus Wilson, obtained from the red grouper, Epinephelus morio, at the Bermuda Islands by Dr. Edwin Linton in $1903,{ }^{1}$ and L. longispinosus Wilson, found on the gills of the hammer-head shark at Beaufort, North Carolina, in $1905 .^{2}$

\section{DENTIGRYPS, nev genus.}

General body form combining the cephalothorax of Lepeophtheirus, an entirely concealed fourth segment, the genital segment of Gloiopotes, and a peculiar abdomen somewhat like that of Alebion. First three thorax segments fused with the head, forming a carapace . whose frontal plates, grooves, and areas are just like those of Caligus and Lepeophtheirus. Fourth and fifth segments fused with the genital segment and the three entirely covered by a single dorsal plate. Attached to the ventral surface of the genital segment, in front of each posterior corner, is a long conical tooth or prong, similar to those on Gloiopotes, but destitute of spines or setæ.

Abdomen attached to the ventral surface of the genital segment some distance in front of the posterior margin. Egg-tubes of medium length and like those of Caligus. Maxillary hooks and furca both present; first maxillæ simple and undivided and some distance behind the mouth tube. First and fourth legs uniramose, second and third biramose, and all similar to those of Caligus.

Type-species.-D. curtus, new species.

(Dentigryps, dens, a prong or tooth, and gryps, a griffin.)

The griffin was a fabulous animal, half eagle and half lion, and thus becomes a fitting name for this new genus which unites the typical characters of quite different genera. It has the carapace and all the appendages of Lepeophtheirus except the first maxillæ, which here are simple and undivided. But there is no free segment, and the fused fourth, fifth, and genital segments are covered with a plate similar to the carapace, the only thorax joint capable of motion being the one between the third and fourth segments where these two dorsal plates come together. A similar condition prevails in the genus Homoiotes. ${ }^{3}$

The ventral prongs or processes on the genital segment are one of the typical characters of the genus Gloiopotes, but here they lack the spines and setæ so commonly found in that genus.

The dropping of the abdomen to the ventral surface and its transference forward is typical of the subfamily Pandarinæ, while the posterior lobes on either side of the anal laminæ are characteristic of such genera as Alebion. 
The present genus is thus a sort of patchwork of parts of other genera and may well serve as another connecting link between those genera. The majority of its characters locate it in the Caliginæ.

DENTIGRYPS CURTUS, new species,

Plate 32, figs. 127-135.

Host and record of specimens.-Six females of this new genus were obtained by Dr. Edwin Linton from the mouth and gill cavities of the cardenal or poison grouper, Mycteroperca venenosa apua, at the Bermuda Islands, July 27, 1903.

Type-specimen.-Cat. No. 43595, U.S.N.M. Paratypes, Cat. No. 42328, U.S.N.M.

Female.-General body form elliptical, short and wide, apparently truncated through the center of the genital segment and thus presenting a curious sawed-off appearance. Carapace orbicular, as wide as long; dorsal grooving like that in Caligus, the crossbars of the $\mathrm{H}$ at the longitudinal center; lateral areas very narrow, only one-third as wide as the thoracic area; posterior sinuses rather deep with flaring sides; posterior margin of thoracic area reentrant. Eyes large and placed well forward; frontal plate narrow and without lunules, but with a distinct median sinus.

Fourth thorax segment so thoroughly fused with the fifth and genital segments as to be indistinguishable except by the fourth legs. These three segments are covered with a strongly arched dorsal plate (probably really a fusion of two plates like that in Homoiotes), which is fully as wide as the thoracic area of the carapace, half as long as wide, and prolonged at each posterior corner into a short blunt lobe. Just in front of each of these lobes on the lateral margin is a large plumose seta. From the ventral surface of the genital segment in front of the lobes a large conical prong extends backward and outward on either side to a level with the tips of the anal laminæ. These prongs are hard and chitinous, perfectly smooth, and are cut off obliquely at the tips. In one female there was a single long, nonplumose spine near the tip of each prong. Egg-cases wide and about as long as the body; eggs large and similar to those of Lepeophtheirus dissimulatus.

On the midline of the ventral surface, between the bases of the prongs, is attached the abdomen. This is one-jointed, somewhat trapezoidal in outline, the same width and length, and just shows its tip behind the dorsal plate of the genital segment. On either side of the anal laminæ the abdomen is prolonged into a short blunt lobe, half the length of the lamina itself. These laminæ are oblong, slightly widened at the tip, and each is armed with three terminal setæ, two on the outer margin and one on the inner. 
First antennæ short, the tips scarcely reaching beyond the free edge of the carapace; terminal joint slender and considerably longer than the basal. Second antennæ stout, the terminal claw bent abruptly near the tip; maxillary hooks small and not much curved. Mouth tube short and blunt; first maxillæ some distance behind the mouth, long, slender, and undivided; maxilliped with a moderately stout basal joint, and a slender terminal claw, half as long as the basal joint, and with an accessory spine on its inner margin near the center.

First legs with no trace of an endopod and with short setæ on the terminal joint; spines on the exopods of the second legs long and stout; rami of third legs close together, spine on the base of the exopod also long and stout; basal joint of the fourth legs the same length as the three terminal joints, inner terminal seta twice the length of the outer and all three terminal ones toothed.

Color, a yellowish-gray, becoming dark cinnamon-brown in the thicker parts of the body.

Total length, $3.6 \mathrm{~mm}$. Carapace, $2.55 \mathrm{~mm}$. long and wide. Fused fourth, fifth, and genital segments, $0.8 \mathrm{~mm}$. long, $1.6 \mathrm{~mm}$. wide.

(curtus, shortened with the idea of being mutilated, the body looking as if some of the posterior part had been cut off.)

Although no specimens of this new genus have yet been obtained from the West Indies, it is almost certain that it will be found there, because its host is even more common there than around Bermuda, and is found as far south as Brazil. There is therefore every reason why it should be included in the present list of parasites.

ANURETES PARVULUS, new species.

Plate 33, figs. 139-147.

Host and record of specimens.-A single female of this interesting species was obtained by Dr. Edwin Linton from the gills of a black angel fish, Pomacanthus arcuatus, at the Marine Laboratory of the Carnegie Institution at the Dry Tortugas, Florida, July 15, 1907.

Type-specimen.-Cat. No. 42275, U.S.N.M.

Female.-Cephalothorax ovate, slightly longer than wide, squarely truncated posteriorly; frontal plates well fused with the head, and furnished with a broad, transparent chitinous margin which evidently functions as a sucking disk. The groove at the crossbar of the $\mathrm{H}$ visible at the sides only, eliminated at the center; lateral areas narrow; thoracic area half of an ellipse, one-third wider than long, a little more than half the width of the cephalothorax, the posterior margin a straight line connecting the tips of the lateral lobes; posterior sinuses mere notches, scarcely visible.

Fourth (free) segment one-fifth the width of the carapace, considerably thickened through the bases of the fourth legs. Genital segment as wide as long, the same shape as the carapace and half as 
wide, narrowed to a neck anteriorly where it joins the fourth segment, with the posterior margin slightly convex, without lobes but bearing the rudiments of both the fifth and sixth legs at the rounded posterior corners.

Abdomen fused into the center of the posterior margin of the genital segment, with only the extreme tip visible on either side of the anus; anal laminæ apparently attached to the genital segment, on a level with its dorsal surface; each is large, triangular, and armed with five plumose setæ. Egg-cases attached on either side of the fused abdomen; eggs large and thick, arranged as in Caligus.

Joints of the first antennæ equal in length, but the basal one four times as wide as the terminal. Second antennæ slender, a small spine on the posterior margin of the basal joint and an accessory claw on the ventral surface of the terminal claw near its base. Maxillary hooks wholly lacking. First maxillæ reduced to mere semicircular stubs on either side of the mouth tube; second maxillæ like those of Caligus. Maxillipeds very large, the basal joint much swollen, the terminal claw as long as the basal joint and bent into a sickle shape, with a small, blunt spine on the inner margin near the base. Mouth tube long and slender, not at all like those of the Caliginæ, but closely resembling those of the Pandarinæ. Swimming legs like those of the Caliginæ; first pair with three terminal claws, three plumose setæ on the posterior margin of the terminal joint, and a rudimentary endopod on the basal joint.

Spines on the exopods of the second legs very long and turned diagonally inward across the succeeding joints. Fourth legs very slender, the basal joint no thicker than the terminal ones.

Color (preserved material), a light gray, the genital segment considerably darker than the carapace.

Total length, $1.2 \mathrm{~mm}$. Carapace, $0.76 \mathrm{~mm}$. long, $0.71 \mathrm{~mm}$. wide. Genital segment, $0.35 \mathrm{~mm}$. long and wide.

(parvulus, very small.)

This single specimen is placed in the genus Anuretes, but differs in some important particulars from the two species already described. The maxillary hooks are not present; the first maxillæ and furca are reduced to mere stubs, hardly distinguishable; the abdomen is plainly fused into the center of the posterior margin of the genital segment, and the anal laminæ are on a level with the dorsal surface of the genital segment instead of being attached to its ventral surface.

In all other particulars it corresponds with the species described by Krøyer and Bassett-Smith. There can be no question that the present specimen is generically distinct from Caligus and Lepeophtheirus, and if, in spite of the above differences, it can be referred to the genus Anuretes, it will establish the validity of that genus satisfactorily. 
MIDIAS LOBODES Wilson.

Midias lobodes Wilson, 1911, p. 625, pl. 65, figs. 1-12.

Host and record of specimens. - This species was originally described ${ }^{1}$ from specimens obtained by Dr. Edwin Linton at the Dry Tortugas, Florida, from the outside surface of the head of a great barracuda (Sphyræna barracuda).

Similar specimens to the number of 40 , including both sexes, were obtained from the same host at Montego Bay, Jamaica.

\section{EURYPHORUS CORYPHAENE Krǿyer.}

Euryphorus coryphænæ KRф́Y ER, 1863, p. 161, pl. 10, figs. 4a-h.

Host and record of specimens.- Several specimens were reported by Krøyer from the gills of the common dolphin, Coryphæna hippurus, in the tropical Atlantic near the West Indies. This is probably the same species as had been named nympha by Steenstrup and Lütken in 1861, which was taken from a "dolphin" near the West Indies.

PARALEBION CURTICAUDIS, new species.

Plate 34 .

Host and record of specimens.-Four females were taken from the gills of a 12-pound red snapper, Neomænis aya, July 2, 1910.

Type-specimen.-Cat. No. 43601, U.S.N.M. Paratypes, Cat. No. 42271, U.S.N.M.

Female.-General body form short and plump; carapace horseshoeshaped, one-fourth wider than long, squarely truncated posteriorly; each side of the $\mathrm{H}$ grooves has a double curve like the letter $\mathrm{S}$, the part posterior to the crossbar with the concave sides, the anterior part with the convex sides, facing each other; this makes the space between the sides anteriorly only one-fourth what it is behind the crossbar. Posterior lobes wide, their tips curved inward so as to overlap the corners of the median lobe and project slightly behind it; lateral areas very wide anteriorly and narrow posteriorly; posterior sinuses shallow and oval.

Median lobe with projecting corners and a somewhat reentrant posterior margin. Free segment nearly half the length of the carapace, narrowed anteriorly and posteriorly but projecting strongly at the bases of the fourth legs. Genital segment subquadrilateral, as wide as long, three-fifths as wide as the carapace, with short and broad posterior lobes.

Abdomen one-jointed, half the length and one-third the width of the genital segment, with a shallow anal sinus; anal laminæ small and nearly spherical, each tipped with three long setæ and one short

1 Proc. U. S. Nat. Mus., vol. 39, p. 626.

$69077^{\circ}$-Proc.N.M.vol.44-13-15 
one. Egg-tubes three-fourths as wide as the abdomen, and about half the length of the body.

Joints of the first antennæ equal in length, the terminal one very slender with a few short spines at the tip.

Second antennæ large and stout, the basal joint reenforced by a stout and blunt spine just behind its insertion. Maxillary hook large and stout and strongly curved, with two blunt spines between its base and that of the maxilla; the latter is triangular with a long and slender point without accessory teeth or spines. Maxillipeds comparatively weak, the terminal claw actually smaller than that of the second antennæ. Furca made up of two short, wide, and squarely truncated rami, strongly divergent and each shaped like an hourglass.

Basal joint of first swimming legs with a small spine on the posterior margin near the proximal end, and a very long and slender one at the anterior distal corner. There is also, attached to the posterior margin near the distal end, a rudimentary endopod, which is one-jointed but divided at the tip. The terminal joint of the exopod has three spines at its tip, but no plumose setæ on the posterior margin.

The spines on the exopods of the second and third legs are exceptionally large and stout, that on the third legs being bent into a half circle. Furthermore, both rami of these third legs are distinctly three-jointed, the division of the joints being similar to that on the second legs and totally different from what is found in the Caliginæ. The basal joint of the fourth legs is unarmed and is about as long as the three terminal joints; the spines at the tips of the second and third joints and the three at the tip of the terminal joint are all about equal in size; the second and third of these spines are reenforced at the base by a membrane with a toothed margin. The fifth lags appear on the posterior lobes of the genital segment, outside of the egg-tubes and close to the lateral margin. Each is distinctly two-jointed, and the terminal joint is tipped with three setæ.

The cement glands are club-shaped, the enlarged glandular portion tapering imperceptibly into the narrow duct. On each of the four females obtained there was also a pair of relatively large spermatophores fastened to the lateral margins of the abdomen. Each spermatophore is spherical, two-thirds as wide as the abdomen, and furnished with a very short duct which leads directly inward from the margin to the opening of the sperm receptacle on the midline. These ducts do not cross, but each empties into its own side of the receptacle.

Color a uniform grayish-white without pigment of any sort. 
Total length, $6 \mathrm{~mm}$. Carapace, $2.65 \mathrm{~mm}$. long, $3 \mathrm{~mm}$. wide. Fourth segment, $1.15 \mathrm{~mm}$. long. Genital segment, $2 \mathrm{~mm}$. long and the same width. Egg-cases, $3.3 \mathrm{~mm}$. long.

(curticaudis, curtus, short, and cauda, tail, in allusion to the very short abdomen.)

The genus Paralebion was instituted ${ }^{\mathbf{1}}$ for some parasites, including both sexes, which were obtained from a shark in Chesapeake Bay. In the type species, elongatus, the genital segment has long and pointed posterior lobes, the abdomen is also long and two-jointed, the furca is double, and there are plumose setæ on the terminal joint of the first swimming legs. In the present species the lobes of the genital segment are broad and short, the abdomen is very short, the furca is single, and there are no plumose setæ on the first legs. In other particulars there is a marked similarity between the two species, with just those differences in detail that would naturally be expected.

\section{Family DICHELESTIIDAE.}

\section{LERNANTHROPUS ANGULATUS Krøyer.}

Lernanthropus angulatus KR $\mathrm{YER}_{\mathrm{ER}}$ 1863, p. 196, pl. 9, fig. 1 a-q.

Host and record of specimens.-This species was originally described by Krøyer from specimens obtained on the gills of a West Indian Serranus, one of the groupers. All the other records are simply copies of this one of Krøyer's, and no other investigator has seen the species. Heller suggests $(1865$, p. 213) that it is identical with the Aethon quadratus previously described by Krøyer. (See p. 192.)

\section{LERNANTHROPUS GIGANTEUS Krøyer.}

Plate 33, figs. 148-150; plate 35.

Lernanthropus giganteus KR $\varnothing \mathrm{YER}, 1863$, p. 206, pl. 8, fig. 1 a-e.-HeIdeR, 1879, p. 345 , pl. 4 , figs. 53 to 55 .

Host and record of specimens.-This species was established by Krøyer in 1863 for a single female obtained from the gills of a "Caranx carangus" taken in Brazil and sent first to the Vienna Museum and thence to the Royal Museum at Copenhagen. This same specimen was afterward examined and described by Heider (1879). "Many specimens" were reported by Bassett-Smith (1898, p. 360) from the gills of "Caranx melamphigus" at Aden in the IndoTropics. In the present instance two lots were obtained, each of which included both sexes; the first from the gills of Caranx crysos is included under Cat. No. 42277, U.S.N.M.; the second from the gills of Caranx hippos, under Cat. No. 42282, U.S.N.M.

Female.-General body form short and rather plump; cephalothorax ovoid, its posterior corners well rounded, with the sides of the carapace projecting considerably in front of the anterior margin. 
Antennal segment small, triangular in shape, and just fitting into the sinus between the projecting sides of the carapace. Second and third segments in the free thorax covered with a dorsal plate trapezoidal in outline, narrowed anteriorly and widened posteriorly, with a short triangular process extending outwards and backwards from each posterior corner opposite the bases of the third legs. Fourth segment with a dorsal plate which is considerably wider than the one just mentioned, and which extends back well beyond the tips of the anal laminæ. In shape it is about three-quarters of an ellipse, the straight edge being separated from the posterior margin of the preceding plate by a well defined groove, and the remainder of the margin being evenly curved, with no posterior sinus. Fifth segment very short and narrow, and having a pair of uniramose fifth legs, which are linear, curved like parenthesis marks, and do not quite reach the posterior margin of the dorsal plate of the fourth segment. Genital segment also short and narrow, bearing on its sides the egg-tubes, and at the posterior corners the large secondary spermatophores.

Abdomen minute, one-jointed, almost completely fused with the genital segment; anal laminæ linear, as long as the entire abdomen, and destitute of setæ or spines. Egg-tubes narrow, and two and a half times the length of the body; eggs thin, numerous, and arranged occasionally in more than a single row. (See fig. 150.)

First antennæ six-jointed and very short; the second pair some distance behind the first, and curved over ventrally between the sides of the carapace so as to be invisible in dorsal view. At their base, where they join the front of the head, they are supported by a stout and complicated chitin framework. The movth tube and mouth parts are carried back so far behind the antennæ that they appear to belong to the thorax rather than the head. Mandibles of the usual pattern; first maxillæ stout, the basal joint swollen, the terminal joint tipped with a straight and stout spine. Second maxillæ simple, the terminal claw stout, nearly straight, and two-thirds as long as the basal joint. Basal joint of maxillipeds much swollen, terminal claw slender, slightly curved, and half the length of the basal joint.

Endopods of first and second legs tipped with a single long and straight spine; exopod of first pair with five terminal saw teeth, exopod of second pair with four. Inside of the endopod of the first legs is a small papilla tipped with a spine.

The third legs are shaped like those of L. gisleri, krøyeri, pagodus, etc., and are distinctly bilobed, one lobe extending backward, the other outward at right angles to the body axis. The rami of the fourth legs are narrow and acuminate and reach for nearly their whole length behind the dorsal plate of the fourth segment. The more or less irregular arrangement of the eggs and the attachment of the spermatophores (fig. 149) are worthy of especial notice. 
Total length, 8 to $9 \mathrm{~mm}$. Cephalothorax, $2 \mathrm{~mm}$. long, $1.6 \mathrm{~mm}$. wide. Thorax, $5 \mathrm{~mm}$. long, $3.6 \mathrm{~mm}$. wide. Egg-strings, 18 to 20 $\mathrm{mm}$. long.

Male.-General body shape elongate and narrow; cephalothorax ovate, with a squarely truncated frontal margin. Antennal area separated from the rest of the head by a well-defined groove as in the female. Posterior body spindle-shaped, the same width as the cephalothorax, but half as long again, with the free thorax, genital segment and abdomen thoroughly fused.

First antennæ relatively much longer than in the female and projecting prominently from the anterior corners of the cephalothorax. Second pair very stout, the basal joint swollen, supported on a complex chitin framework, and armed on the inner margin near the proximal end with a short tooth. Mouth parts as in the female, the basal joint of the maxilliped being considerably stouter. First legs with minute one-jointed rami, the endopod with one spine longer than the ramus itself, and a second much shorter one, the exopod with four short saw teeth.

Endopod of second legs tipped with a single large spine the same length as the ramus; exopod enlarged toward the tip, where it carries two minute spines interspersed with a row of short hairs. Third legs with a short basal portion, an exopod two-thirds as long as the entire body, and an endopod reduced to a mere knob on the inner margin of the basal portion at its tip.

Fourth legs as long as the entire body, basal portion projecting well beyond the lateral margins; rami about the same size and length.

Total length, not including the legs, $2.75 \mathrm{~mm}$; including the legs, $4 \mathrm{~mm}$. Cephalothorax, $0.95 \mathrm{~mm}$. long, $0.75 \mathrm{~mm}$. wide. Posterior body, $0.75 \mathrm{~mm}$. wide, $1.8 \mathrm{~mm}$. long. Fourth legs, $2.5 \mathrm{~mm}$. long.

Color of both sexes, a dark yellowish-gray, without pigment markings of any sort.

(giganteus, of large size.)

Hitherto there have been but two descriptions of this species, both made from the same (single) female; to these is now added the present description and drawings from an abundance of living material, taken on new hosts and in a different locality and including for the first time the male sex. We thus get acquainted with the variations in size and structure and the relative proportions of the male.

The species is readily distinguished by its size, by the narrow cephalothorax with its sides projecting in front of the anterior margin, by the short projections of the dorsal shield opposite the bases of the third legs, by the very long and narrow fourth legs, which reach far behind the dorsal shield of the fourth segment, and by the threadlike fifth legs, curved like parenthesis marks. The species is still among the largest in the genus and is one of the few instances where the original "giant" has retained its prestige. 
LERNANTHROPUS FRONDEUS, new species.

Plate 36 .

Host and record of specimens.-Ten specimens, containing both sexes, were obtained from the gills of the red snapper, Neomænis aya, on July 16, 1910.

Type-specimen.-A female, Cat. No. 43520, U.S.N.M. Paratypes, Cat. No. 42287, U.S.N.M.

Female.-General body form elongate, narrowed anteriorly and widened posteriorly; cephalothorax ovate, less than one-third the length of the body exclusive of the legs, and about the same width as the second and third thorax segments. Carapace projecting neither along the lateral margins nor in front, leaving the first and second antennæ entirely visible in dorsal view. Second and third thorax segments separated by a distinct groove, the former short with strongly convex margins, the latter twice as long with nearly straight margins. Dorsal plate of the fourth segment broadly kidney-shaped, nearly twice the width of the third segment, with a very evenly curved outline. Fifth and genital segments and abdomen so short as to be considerably wider than long, but well defined and separated from one another by grooves. Anal laminæ much enlarged and foliaceous, each being half as wide again, and more than five times as long, as the abdomen. Egg-strings narrow and tapering posteriorly, nearly twice as long as the body; eggs thin and numerous.

First antennæ small but prominent, seven-jointed; antennal area wide and separated from the rest of the head by a well-defined groove; second antennæ stout, the basal joint considerably longer than the terminal claw, and carrying on its inner margin near the center a small papilla tipped with a hair-like spine, First maxillæ stout, the terminal joint as thickset as the basal and tipped with three spines, the central one of which is longer than the other two. Second maxillæ with a slender terminal claw, the same length as the swollen basal joint and slightly enlarged at the tip. Basal joint of maxillipeds much swollen, terminal claw conical and shorter than the basal joint. Exopods of first two pairs of legs wider than the conical endopods and considerably flattened; first exopod armed with five short and stout spines; second exopod with three spines and two short teeth on the outer margin. Each endopod carries a single long and stout spine.

Third legs uniramose, each shaped like an ovate leaf with an acuminate tip; each leg is three-fourths as wide as the third segment itself, and as they do not overlap on the midline it follows that they project from the lateral margins of the third segment even beyond the level of the dorsal plate on the fourth segment. Fifth legs also 
shaped like an ovate acute leaf, each actually wider than the fifth segment and reaching well beyond the posterior margin of the dorsal plate of the fourth segment. Fourth legs biramose, each ramus broad and leaf-like at the base and tapering into a long and acuminate tip, which shows for nearly its entire length beyond the posterior margin of the dorsal plate of the fourth segment.

Total length, without legs, $8 \mathrm{~mm}$; with fourth legs, $11.5 \mathrm{~mm}$. Cephalothorax, $3 \mathrm{~mm}$. long, $1.9 \mathrm{~mm}$. wide. Dorsal plate on fourth segment, $3.2 \mathrm{~mm}$. wide, $2.5 \mathrm{~mm}$. long.

Male.-General body form oblong, the same width throughout, three times as long as wide. Cephalothorax ovate, three-sevenths of the entire length; antennal area distinctly separated and much narrower than the remainder of the cephalothorax. Free thorax, genital segment, and abdomen well fused, without transverse grooves, but with marginal invaginations indicating the segmentation. Genital segment considerably narrower than the free thorax; anal laminæ elongate and flattened, but not as foliaceous as in the female. Appendages similar to those of the female, the terminal claws of the second maxillæ and maxillipeds longer and sharper. Third and fourth legs biramose, slender, and thread-like; endopod of third pair rudimentary and very short; endopod of fourth pair much shorter than the exopod, which latter is nearly as long as the entire body; fifth legs wanting.

Color of both sexes a creamy yellow, without pigment markings.

Total length, without fourth legs, $3.5 \mathrm{~mm}$; ; with fourth legs, 5.5 $\mathrm{mm}$. Cephalothorax, $1.5 \mathrm{~mm}$. long, $1 \mathrm{~mm}$. wide. Posterior body, $2 \mathrm{~mm}$. long, $0.9 \mathrm{~mm}$. wide.

(frondeus, covered with leaves, in allusion to the shape of the third, fourth, and fifth legs and the anal laminæ in the female.)

Nauplius larva.-Body shield-shaped, with square anterior corners and a pointed posterior margin. Eye very far forward, just behind the anterior margin. Appendages of the usual pattern, the three pairs of about the same length. Balancers far back on either side of the posterior point, curved outward and forward, rather short and stout. Center of the body filled with a dark mass of cinnamonbrown pigment, leaving only a narrow margin clear. This mass of pigment makes the egg-strings of the adult female very dark brown just before they are ready to hatch.

This species can be readily distinguished by the broad and foliaceous legs and anal laminæ of the female, and by the fact that the cephalothorax and free segments of both sexes are about the same width. The two pairs of antennæ are also peculiarly prominent in dorsal view. It is one of the larger species, and gives an excellent typical idea of the genus which it represents. 
LERNANTHROPUS OBSCURUS, new species.

Plate 37.

Host and record of specimens.-Both sexes of this species were taken from the gills of the yellow tail, Ocyurus chrysurus, July 23, 1910.

Type-specimen.-A female, Cat. No. 43600, U.S.N.M. Paratypes, Cat. No. 42332, U.S.N.M.

Female.-General body form short and fairly plump; cephalothorax elliptical, a little longer than wide; antennal area well defined, second antennæ not visible in dorsal view; second and third thorax segments about the same length and width as the cephalothorax, with a shallow lateral sinus between them; sinus between the third and fourth segments narrow and deep; dorsal plate of fourth segment as long as the cephalothorax and half as wide again, with a deep sinus in the center of the posterior margin; fifth and genital segments and abdomen diminishing regularly in length and width; anal laminæ broad and foliaceous and as long as the three preceding segments combined.

First antennæ of the usual pattern and rather plump, very indistinctly segmented toward the base. Second antennæ with swollen basal joints, destitute of any tooth on the inner margin, and a short, rather slender, and strongly curved terminal claw. First maxillæ with a long terminal joint, tipped with two short and equal spines. Basal joints of second maxillæ and maxillipeds much swollen; terminal claws slender, but nearly as long as the basal joints. Rami of first two pairs of legs of the usual pattern, but stouter than in most species. Third legs uniramose, longer than the second and third segments together, and somewhat widened and flattened at the base so as to be semifoliaceous. Fourth legs biramose, rami elongateconical, exopods slightly longer than the endopods, and both projecting for nearly their entire length behind the dorsal plate of the fourth segment. Fifth legs narrow foliaceous, well flattened, and just reaching the posterior margin of this same dorsal plate.

Total length, $6.5 \mathrm{~mm}$., with the fourth legs; $4.35 \mathrm{~mm}$. without them. Cephalothorax, $1.5 \mathrm{~mm}$. long, $1.35 \mathrm{~mm}$. wide. Second and third segments, $1.5 \mathrm{~mm}$. long, $1.25 \mathrm{~mm}$. wide. Dorsal plate of fourth segment, $1.5 \mathrm{~mm}$. long, $1.9 \mathrm{~mm}$. wide.

Male.-General body form spindle-shaped; cephalothorax ovate, nearly half the entire length of the body proper; antennal area considerably narrowed and separated by a well-defined groove; posterior body without transverse grooves, but with the segmentation indicated by marginal sinuses, widest through the third segment and thence tapering rapidly backwards; anal laminæ linear, divergent, each tipped with two minute spines.

Appendages like those of the female, with a few exceptions. 
The outer terminal spine of the first maxillæ is much shorter than the inner one; the terminal claws of the second maxillæ and maxillipeds are relatively shorter; the rami of the first and second legs are less plump; the third and fourth legs are both uniramose, and the rami are narrow-cylindrical.

Color of both sexes a light yellowish-white, without pigment.

Total length, with fourth legs, $3 \mathrm{~mm}$; without them, $2 \mathrm{~mm}$. Cephalothorax, $1 \mathrm{~mm}$. long, $0.66 \mathrm{~mm}$. wide. Posterior body, $1 \mathrm{~mm}$. long, $0.66 \mathrm{~mm}$. wide.

(obscurus, obscure or hidden, in the sense that the species does not possess any very marked characters.)

This species has to be recognized by an aggregation of characters rather than by any one or two. The narrow second and third thorax segments, the deep sinus between the third and fourth segments, the uniramose third legs and the very long fourth legs, make a combination found in no other species.

It is not at all common, being found on but a single fish during the entire season.

LERNANTHROPUS SPICULATUS, new species.

Plate 38, figs. 185-189.

Host and record of specimens.-A single lot, consisting of three females, was obtained from the gills of the lane snapper, Neomænis synagris, July 15, 1910.

Type-specimen.-Cat. No. 43598, U.S.N.M. Paratypes, Cat. No. 42279, U.S.N.M.

Female.-General body form oblong, four times as long as wide; cephalothorax ovate, the lateral margins projecting anteriorly in the form of a short knob or horn on either side. A distinct notch in each margin indicates the separation of the antennal area from the rest of the head, but there is no transverse groove. Fused second and third segments subquadrilateral, with parallel sides and nearly square corners, the separation of the two segments being faintly indicated by marginal notches. Dorsal plate of the fourth segment obovate, the posterior margin slightly reentrant at the center. Third legs entirely concealed in dorsal view; both rami of the fourth pair projecting far behind the dorsal plate. Fifth segment short and destitute of appendages; genital segment also short and narrow.

Abdomen subquadrilateral, the same length and width; anal laminæ as long as the genital segment and abdomen, stout, with their tips curved away from each other. But in spite of their length they only reach halfway to the posterior margin of the fourth dorsal plate, and hence this extreme posterior portion of the body is entirely concealed in both dorsal and ventral views.

None of the females captured carried egg-strings and so these are unknown. 
First antennæ small, very rudimentary, and entirely destitute of setæ or spines; they are also concealed between folds of the carapace so as to be invisible. Second pair of good size, the basal joint much swollen, the terminal claw stout and strongly curved. First maxilla with a large terminal joint tipped with two spines; second maxilla with a moderately swollen basal joint, and a long and weakly curved claw. Maxillipeds with a very stout basal joint and a short terminal claw, bent abruptly near the base, but for the rest of its length almost straight.

First legs rudimentary, without spines or setæ and well concealèd beneath the maxillipeds; the second pair are reduced to mere knobs on the ventral surface of two prominent ridges running parallel with the body axis, one on either side of the midline and quite close to it. The third legs are of the usual plicate form, separated to their base along the midline, and leaving concave grooves externally and internally, but with the anterior margin a straight line. These legs reach only a trifle beyond the posterior margin of the third segment. The fourth legs are biramose; each ramus is enlarged at the base and then rapidly tapers to a long, cylindrical and bluntly pointed tip; the two legs almost touch along the midline and entirely conceal the fifth and genital segments and the abdomen.

Color a yellowish-gray, without pigment markings of any sort.

Total length $6.12 \mathrm{~mm}$. with the fourth legs, $4.75 \mathrm{~mm}$. without them. Cephalothorax $1.35 \mathrm{~mm}$. long, $1 \mathrm{~mm}$. wide. Second and third segments $1.35 \mathrm{~mm}$. long, $1.70 \mathrm{~mm}$. wide. Fourth dorsal plate $2.2 \mathrm{~mm}$ long, $1.62 \mathrm{~mm}$. wide.

(spiculatus, furnished with spines or points, alluding to the pointed tips of the fourth legs.)

This species may be recognized by the long and sharp-pointed rami of the fourth legs, which project very prominently behind the fourth dorsal plate, by the entire concealment, in both dorsal and ventral views, of the fifth and genital segments and abdomen, by the very rudimentary form of the second legs and antennæ, and by the size and shape of the anal laminæ.

SAGUM, new genus.

General body form similar to that of Lernanthropus. Cephalothorax irregular in outline, the antennal area being separated from the head by deep marginal sinuses, forming a sort of beak or rostrum, and the carapace being produced into a broad, irregular wing on each lateral margin. Posterior body covered with a single dorsal plate, which is prolonged at the posterior corners of the third segment into very large lobes, and is continuous through the center of the body with the dorsal plate of the fourth segment. Antennæ and mouth parts similar to those in Lernanthropus; each of the first and second 
legs reduced to a simple one-jointed process, bipartite at the tip; third legs with a broad and laminate endopod reaching back beyond the tips of the fourth legs and covering them ventrally; rami of fourth legs laminate at the base, flagellate at the tip. Fifth and genital segments and abdomen reduced and concealed as in Lernanthropus; anal laminæ short, turned over ventrally and enlarged into four blunt lobes at the tip. Egg-tubes unknown.

\section{Type-species.-Sagum flagellatum.}

(Sagum, a military cloak, alluding to the shape of the fused dorsal plates covering the thorax.)

SAGUM FLAGELLATUM, new species.

Plate 39.

Host and record of specimens.-Two females of this new genus and species, both lacking the egg-strings, were obtained from the gills of the rock hind, Epinephelus adscensionis, August 9, 1910.

Type-specimen.-Cat. No. 42280, U.S.N.M.

Female.-General body form short and stout, the division into body regions very indistinct. Cephalothorax short, a little more than one-fourth of the entire length and one-fifth wider than long; deeply notched on either side just back of the antennal area, the portion between the notches forming a broad rostrum one-third as long as the rest of the cephalothorax. This is a condition very similar to that found in the genus Abasia. ${ }^{1}$ The carapace is prolonged forward on either side of this rostrum as a short process or wing, and outward on either lateral margin as a large triangular wing.

These wings, in addition to the rostrum, give the cephalothorax a very irregular outline. The second, third, and fourth segments are so thoroughly fused that there is no indication of any joints, and they are covered with a single, continuous dorsal plate. On either side of the cephalothorax the second segment projects forward in a broad, rounded knob, like a pair of shoulders. The posterior corners of the third segment are similarly prolonged backward and outward like the skirts of a long military cloak. The part corresponding to the fourth dorsal plate in Lernanthropus is as wide as both these posterior skirts together, and about the same length as the rami of the third and fourth legs. The fifth and genital segments and abdomen are entirely concealed between the third and fourth legs and the dorsal carapace. The fifth segment is rather long and narrow and destitute of appendages; the genital segment is transversely elliptical and a little shorter than the fifth segment.

The abdomen is half the width of the genital segment; the anal laminæ extend outward ventrally at right angles to the body axis and are enlarged at the tips into an irregular four-lobed mass; the 
laminæ are so short that these masses seem to rest directly upon the ventral surface of the abdomen.

First antennæ six-jointed, slender, and well armed with setæ; second pair stout, with swollen basal joints and short and stout terminal claws. First maxillæ simple, two-jointed, and tipped with a single short and stout spine; second maxillæ and maxillipeds with short and rather weak terminal claws, and moderately swollen basal joints.

First and second legs very rudimentary, each leg consisting of a one-jointed process divided at the tip. In the first legs these processes are short and broad, but in the second legs they are narrow and acuminate. The third and fourth legs are peculiar and quite different from anything thus far found in Lernanthropus. The third pair on the outside pass insensibly into the posterior skirts of the third segment; in the center is a short plicate portion, and on the inside is a long and flattened endopod, pointed at the tip, which reaches back beyond the fourth legs to the posterior border of the fourth dorsal plate. These legs therefore cover and conceal the fourth pair, a condition never found in Lernanthropus. The fourth legs are made up of a narrow endopod and a much wider exopod, each strongly flattened and enlarged into the shape of a spatula, and furnished with a narrow tip like a whiplash, attached to the end of the endopod and to the inner margin of the exopod. The function of these flagellate portions is difficult to surmise.

Color a uniform yellowish-gray without pigment markings.

Total length, $5.75 \mathrm{~mm}$. Cephalothorax, $1.45 \mathrm{~mm}$. long, $1.85 \mathrm{~mm}$. wide. Second thorax segment, $2.95 \mathrm{~mm}$. wide. Third segment, 4 mm. wide.

(flagellatum, furnished with flagella or whiplashes, alluding to the fourth legs.)

This genus may be readily distinguished from Lernanthropus by the rostrum and wings of the cephalothorax, by the long endopods of the third legs, and by the lash-like tips of the fourth legs. They are not at all common, this one lot being all that were found for the entire season.

NEMESIS VERSICOLOR, new species.

Plate 38, figs. 190-194; plate 40.

Host and record of specimens.-A single lot of six specimens, including both sexes, was obtained from the gills of the hammer-head shark, Sphyrna zygæna, June 17, 1910. The females were found on the tips of the gill filaments, indiscriminately arranged, while the males were attached to the inner surface of the filaments some distance from the tips.

Type-specimen.-A female, Cat. No. 43602, U.S.N.M. Paratypes, Cat. No. 42294, U.S.N.M. 
Female.-General body form oval, two and one-half times as long as wide, narrowed a little anteriorly and much more posteriorly.

Cephalothorax covered by a carapace which is slightly longer than wide and only two-thirds of the width of the second segment, with a knob on each lateral margin just in front of the center. Second, third, and fourth segments each covered with a semicircular carapace which extends around the sides of the body to the ventral surface, the three carapaces all about the same size. Fifth segment narrowed to half the width of the fourth and covered on the dorsal surface only with a carapace, which is transversely elliptical and does not reach the posterior margin of the segment. Genital segment one-third narrower than the fifth segment, nearly twice as wide as long, with the egg-strings attached close to the lateral margins.

Abdomen less than half the width of the genital segment and about the same length, made up of three joints, the terminal of which is as long as the two basal together. Anal laminæ oval in outline, twothirds as long as the entire abdomen, each tipped with four short spines.

Egg-cases the same width as the abdomen, and from one to one and two-thirds times the length of the body; eggs large, from 25 to 40 in each case.

First antennæ slender and many-jointed, tapering gradually to the tip, and attached to the anterior margin of the head close to the dorsal surface. Second antennæ four-jointed, the terminal joint a long sickle-shaped claw; the third and fourth joints project nearly their length in front of the anterior margin of the head, and form important accessory attachment organs.

The second maxillæ are two-jointed, the joints about the same length, the terminal one with two projections at the tip on the anterior margin, each elliptical in outline, and about as long as the terminal joint is wide. Maxillipeds very large and sickle-shaped, projecting their entire length beyond the margin of the carapace, two-jointed, the terminal joint a claw which is slightly shorter than the basal joint. The tip of this claw is stained a deep red as though with blood.

The first pair of legs is considerably modified in form; the basal joint of the exopod is curved inward, narrowed at the base and enlarged at the tip into a broad spatula, with the tiny terminal joint attached to the center of the terminal margin. The endopod is made up of three parts; the outer of these is very narrow, longer than the others, sickle-shaped, and curves outward over the basal joint of the exopod, with a row of long cylindrical teeth along the concave and convex margins; the other two parts are shorter and stouter and are covered with short spines. The second, third, and fourth legs are biramose, the rami are two-jointed, and the terminal 
joint is considerably narrower than the basal. The exopod of each pair is attached to the outer margin of the basal joint, the endopod to the posterior margin. The basal joint of each ramus carries a stout spine on either side of the terminal joint; the latter carry six spines except in the endopods of the third and fourth legs, where they have only four.

Color a lemon-yellow, inclined to orange on the dorsal surface, the tips of the maxillipeds a dark blood-red, the digestive tube a deep blue-black. Egg-strings sulphur-yellow, turning pink with development.

Total length, $3.1 \mathrm{~mm}$. Carapace, $0.8 \mathrm{~mm}$. long, $0.75 \mathrm{~mm}$. wide. Second thorax segment, $1.15 \mathrm{~mm}$. wide. Egg-strings, 3 to $5 \mathrm{~mm}$. long.

Male.-Body narrow and elongated, about the same diameter throughout the thorax, the abdomen only one-third as wide. Carapace oblong, one-third longer than wide, with nearly straight anterior and posterior margins. First thorax segment partially separated from the head; second, third, and fourth segments increasing much in length and slightly in width. Fifth segment one-third the length of the fourth segment; genital segment the same length as the fifth segment but not as wide; abdomen two-jointed, joints the same length; anal laminæ narrow and elongate, each tipped with three short spines.

First antennæ stouter than in the female, the basal joints much larger than the terminal; second pair comparatively small and slender, the terminal claw very weak. First maxillæ with a rudimentary endopod and exopod, each one-jointed and tipped with two spines; second pair with a large claw arising from the anterior margin at the tip of the terminal joint, and curving around the end so as to point backward.

Maxillipeds modified into huge chelæ, the dorsal jaw stout and bluntly rounded at the tip, the ventral jaw a slender pointed claw, its tip curved around the end of the dorsal jaw, and with a fringe of short hairs along the posterior margin.

First four pairs of legs biramose; the first pair very rudimentary, both rami one-jointed and tipped with two short spines; exopods of second, third, and fourth pairs attached to the outer margin of the basal joint as in the female; exopod of second pair four times the length of the endopod and two-jointed, the terminal joint tipped with four spines; endopod minute, one-jointed, with three spines; rami of third pair about the same length, exopod three-jointed with five spines, endopod two-jointed with a single terminal spine; endopod of fourth pair longer than the exopod, two-jointed, with a single terminal spine much longer than the ramus itself; exopod threejointed with five spines; fifth legs stout, but one-jointed, with a single tiny spine near the tip. 
Color similar to that of the female.

Total length, $1.70 \mathrm{~mm}$. Carapace, $0.66 \mathrm{~mm}$. long, $0.25 \mathrm{~mm}$. wide. Fourth thorax segment, $0.5 \mathrm{~mm}$. long, $0.3 \mathrm{~mm}$. wide.

(versicolor, variegated in color.)

This West Indian species is quite different from the one found upon the sharp-nosed shark, Scoliodon terræ-novæ, farther north, off the coast of Georgia and the Carolinas.

If we contrast the females we notice first that the cephalothorax is relatively larger in the northern form, and has evenly curved margins, without any projections. But there is a tooth on each lateral margin of the second segment, a shallow sinus in each lateral margin of the fourth segment, and the dorsal plate of the fifth segment is three-lobed posteriorly, none of which conditions are found in the southern species. The fifth and genital segments and the abdomen are also relatively much larger in the northern form; there are minor differences in the antennæ, mouth parts, and swimming legs.

When we compare the males we find far greater distinctions. In the northern form the body is about the same width throughout; the carapace is a regular ellipse, one-third of the entire length, and wider than any of the following segments; the second, third, and fourth segments diminish regularly in width and length; the maxillipeds have simple and regular claws. In the West Indian species, on the contrary, the carapace is oblong, with nearly straight sides, is less than one-fifth the entire length, and is considerably narrower than the fourth segment; the second, third, and fourth segments increase considerably in length and width; the maxillipeds form a well defined chela instead of a simple claw.

\section{HATSCHEKIA ALBIRUBRA, new species.}

Plate 41, figs. 209-215.

Host and record of specimens.-Four females of this new form, all without the egg strings, were taken from the gills of the lane snapper, Neomænis synagris, July 16, 1910. They are made paratypes and have been given Cat. No. 42288 , U.S.N.M.

Another lot, also of four females without egg strings, was obtained from the gills of the yellowtail, Ocyurus chrysurus, on August 4.

Type-specimen.-Cat. No. 43591, U.S.N.M. Paratypes Cat. No. 42309, U.S.N.M., both from the yellow-tail.

Female.-General body form elongate, three and one-half times as long as wide; carapace small, only one-eighth the entire length and much narrower than the thorax, transversely elliptical, one-third wider than long, with an evenly curved outline.

Fused frontal plates projecting from the frontal margin; dorsal median carina well defined and divided into a $Y$ anteriorly. Fused 
thorax elongate, club-shaped, the wide end anterior, with nearly straight lateral margins, which converge posteriorly, the segmentation being clearly indicated by marginal indentations. The two leg-bearing segments are the same width as the carapace, but much narrower than the third segment, thus forming a short and wide neck. Third segment rather abruptly widened to one and threequarters times the diameter of the first two segments, and then, with the fourth and fifth segments tapering regularly backward to the base of the sixth segment, without any posterior lobes. Sixth segment and abdomen semicircular, one-third the diameter of the fifth segment; anal laminæ narrow oblong, each tipped with two minute spines.

Egg-strings of medium width and half as long as the body; eggs large, eight or nine in each string.

First antennæ closely appressed to the frontal margin of the carapace and scarcely reaching its lateral margin, with setæ on the two terminal joints only. Terminal claw of the second antennæ slender, three-quarters as long as the stout triangular basal joint, abruptly bent at a right angle near its base, with the free end strongly curved inward. Maxillæ present as minute papillæ beside the mouth tube, each tipped with three tiny spines. The two terminal joints of the maxilliped are considerably longer than the moderately stout basal joint; the terminal claw has an accessory spine on its inner margin near the tip. The swimming legs have stout basal joints and wide rami; the first exopod is tipped with four spines, the second with three, and each endopod with five; there is a long and stout spine on the basal joint of the first legs, inside of the endopod, and a much smaller one in a similar position on the second legs.

Color a light lemon-yellow, the lacunæ filled with bright red blood; these lacunæ are thickest along the lateral margins, giving them a bright orange color, with an irregular red line through it; this red line widens at the anterior and posterior ends of the oviducts. The muscles of the head and the first two thorax segments are also bright red; the oviducts and freshly extruded eggs are snow-white.

Total length, $1.75 \mathrm{~mm}$. Carapace, $0.32 \mathrm{~mm}$. wide, $0.25 \mathrm{~mm}$. long. Fused thorax, $1.42 \mathrm{~mm}$. long; third segment, $0.5 \mathrm{~mm}$. wide.

(albirubra, albus, white, and ruber, red.)

This species most resembles $H$. oblonga (see p. 242) from the red snapper, but it may be easily distinguished by the fact that the carapace is much narrower than the fused thorax, while the latter is much wider anteriorly than posteriorly. Again, the rich pink-red color of the present species and the snow-white ovaries and oviducts form a striking contrast not known to occur in any other species, and finally the stout basal joint of the second antennæ is very different from the long and slender basal joint in oblonga. 
In connection with this species the author had an unusual and very interesting experience. When first obtained none of the females had any portion of their egg-strings, but two of them extruded their eggs while being examined under the microscope.

The conditions were artificial, to be sure, and yet the method was suggestive and well worth recording. The two females writhed convulsively for some time, contracting the longitudinal body muscles with especial violence. So vigorous were these convulsions that at first it was supposed some chemical had gotten into the sea water in the watch glass, but this was afterwards conclusively disproved. The cement glands were the first to respond, and they poured out enough of their secretion to form a pair of empty cases the full length of the completed egg-strings. These were narrow, hollow, elastic, and tapered to a sharp point at their tips. Into these the eggs were forced, one at a time, each egg requiring severe contraction to force it through the external opening of the oviduct. As it issued into the external case it distended the latter considerably, thereby proving it to be elastic. The first egg remained close to the genital segment until it was pushed along by the extrusion of the second one, and this by the third, and so on. The tip of the case remained all the while much narrower than the part filled by the eggs, and was sharply pointed until finally the first egg was pushed back into it and rounded it out into its usual form.

So far as known the extrusion of the egg cases has never before been witnessed among the Dichelestiidæ, and from it we may deduce the following:

1. The cement substance which forms the external case is not extruded piecemeal along with each egg, but the full amount necessary to form the case is pushed out before any egg is laid, and has a chance to stiffen somewhat in contact with the sea water before the first egg enters it.

2. The bag thus formed previous to the issuance of the eggs is not smooth; each muscular contraction seems to push out a certain amount of the substance, approximately enough to cover one egg, and between these successive portions the bag is slightly constricted, making it appear segmented.

3. The bag is but little more than half the diameter of the eggs and tapers to a sharp point at its tip; hence it must stretch as the eggs are pushed into it. At first it appears to be quite elastic, but loses this quality with every successive stretching and soon remains distended so that the eggs slip along through it easily.

4. Each egg remains close to the body until pushed backward by the issuance of the next one, the tip of the bag hanging loosely like the finger of a glove that is being put on for the first time.

$69077^{\circ}$-Proc.N.M.vol.44-13-16 
5. Under such conditions the number of eggs in any given string is determined at the beginning by the size of the original case.

This is very different from what is found in the Caligidæ, where there are partitions between the individual eggs, or in the Ergasilidæ, where the eggs ripen individually or in small groups.

Probably each method of extrusion is more or less characteristic of the family represented.

\section{HATSCHEKIA OBLONGA, new species.}

Plate 42 , figs. 222-226.

Host and record of specimens.-Ten specimens of this species were obtained from the gills of the red snapper, Neomænis aya, all females, three of which carried egg-strings. They were fastened between the gill filaments, the head usually on the inner surface of the filament, and the body at right angles to it. While fairly common they were not at all numerous.

Type-specimen.-Cat. No. 43554, U.S.N.M. Paratypes, Cat. No. 42319, U.S.N.M.

Female.-General body form oblong, four and one-half times as long as wide; carapace small, one-fifth of the entire length, transversely elliptical, one-third wider than long, with very evenly curved margins. Fused frontal plates also transversely elliptical and projecting their entire length from the frontal margin. Dorsal median carina of the carapace well developed. Fused thorax segments cigar-shaped, tapering posteriorly; first and second segments forming a neck, one-third narrower than the third segment and connecting the latter with the carapace. Third, fourth, and fifth segments indistinguishably fused, with neither marginal indentations nor grooves; fifth segment ending in a blunt lobe on either side of the sixth segment. The latter and the abdomen semicircular, two-fifths the width of the fifth segment; anal laminæ narrow-oblong, each tipped with two minute spines.

Egg-strings half the length of the body, considerably wider than the genital segment, curved like parenthesis marks, and each containing about 15 eggs.

First antennæ closely appressed to the anterior margin of the carapace and scarcely reaching its lateral margin. Second pair with a terminal claw half the length of the slender basal joint, and bent sharply at a right angle close to its base. The slender second and third joints of the maxillipeds are together about the same length as the much stouter basal joint. Each of the swimming legs has a short and wide basal joint, a slender two-jointed exopod tipped with two spines, and a stout one-jointed endopod tipped with a single stout spine; each basal joint carries a small papilla, tipped with a stout spine, just inside the base of the endopod. The cement 
glands are long and slender, the glandular portion one-third of their entire length. Color similar to that of $H$. linearis from the redmouthed grunt. (See p. 247.) Head yellowish with a faint tinge of brown, more noticeable on the chitin ribs and the thicker portions of the integument; free thorax and genital segment with yellow margins tinged with olive-green; inside of these the long oviducts are yellowish anteriorly, then become light brown and eventually dark cinnamon-brown posteriorly; the central line over the intestine yellowish with orange margins; egg-strings dark cinnamon-brown. There are none of the dark red streaks through the head and free thorax so prominent in linearis.

Total length, $1.70 \mathrm{~mm}$. Carapace, $0.36 \mathrm{~mm}$. wide, $0.27 \mathrm{~mm}$. long. Fused thorax, $1.27 \mathrm{~mm}$. long, $0.36 \mathrm{~mm}$. wide. Egg-strings, $0.82 \mathrm{~mm}$. long, $0.145 \mathrm{~mm}$. wide.

(oblongus, oblong.)

This species may be distinguished by its oblong form, its small elliptical carapace of the same width as the fused thorax, by the narrowing of the first two thorax segments, and by the short curved egg-strings. It is fairly common on the red snapper, but only one or two specimens are found on a fish.

HATSCHEKIA UNCATA, new species.

Plate 43.

Host and record of specimens.-A dozen females, nearly all with egg-strings, were obtained from the gills of the rock hind, Epinephelus adscensionis, July 12, 1910. They were fastened to the gill filaments, close to the base of the latter, and in the space between two adjacent filaments, in such a way that their bodies were entirely concealed, and only the egg-strings were visible. The body axis was at right angles to the length of the filament, thus bringing the egg-strings parallel with the latter, and just flush with its outer surface. The dozen specimens were obtained from half as many fish.

Type-specimen.-Cat. No. 43546, U.S.N.M. Paratypes, Cat. No. 42289, U.S.N.M.

Female.-General body form elliptical, short and plump; well rounded on both dorsal and ventral surfaces, more on the former than the latter. Carapace relatively large and semicircular, onethird of the entire length and one-half wider than long; the frontal and lateral margins form a nearly perfect half circle, surrounded by a wide transparent border; the posterior margin is three-lobed, the lateral lobes narrow and short, the median lobe three-fifths of the entire width and strongly convex. The anterior margin projects between the bases of the first antennæ, which are attached dorsally. Fused thorax segments broadly elliptical, one-fifth longer than wide, the segments indistinguishable except by indentations on the lateral 
margins. The two anterior leg-bearing segments separated from. the remainder by portions of a groove, extending inward from each lateral margin. Fifth segment bearing a good-sized hemispherical knob on its posterior border on either side, just external to the opening of the oviduct. The location of these knobs, combined with the position in which the egg-strings are habitually carried, suggests strongly that they are concerned in the support of the latter. Sixth (genital) segment indistinguishably fused with the abdomen, the two forming a triangular projection, one-half wider than long, attached to the center of the posterior border of the fifth segment, between the two knobs. The oviduct openings are dorsolateral, and as close as possible to the fifth segment. Anal laminæ conical, twice as long as wide, half the length of the fused sixth segment and abdomen, each tipped with three setæ of equal length, and having a short spine on the outer margin.

Egg-strings each one-third the width of the fused thorax and twothirds of its length; eggs remarkably large compared with the size of the animal, only four or five in each case. The two cases are rotated until, with their bases touching at the midline, they are carried in front of a line at right angles to the body axis, and are actually curved forward like the points of a pickax, or even as far as the flukes of an anchor.

First antennæ indistinctly five-jointed, the same diameter throughout, only the three terminal joints armed with setæ; they are usually closely appressed to the lateral margins of the carapace. Second antennæ with a stout basal joint, which is contracted and curved inward at the distal end; terminal claw short, stout, and evenly curved. Mouth tube short, scarcely as long as wide, with a blunt tip; maxillæ reduced to mere knobs, destitute of spines or setæ. Maxillipeds with the two terminal joints together the same length as the basal joint, but only half the width of the latter. Swimming legs biramose, each ramus two-jointed; in the exopods the basal joint is the longer, in the endopods the terminal joint. In the first legs the basal joints are unarmed, the terminal endopod joint carries four short spines, the exopod three. In the second legs each basal joint is armed with a curved spine, on the outside in the exopod, on the inside in the endopod; the terminal exopod joint carries two curved spines, the endopod three.

Color variegated, the lateral margins a light olive-green, the ovaries and oviducts a light cinnamon-brown, the vascular space between the oviducts and intestine orange-yellow, the stomach and intestine contents a dark wine-red, filled with black globules along the center, which are most numerous at the anterior end.

Total length, $1 \mathrm{~mm}$. Carapace, $0.31 \mathrm{~mm}$. long, $0.4 \mathrm{~mm}$. wide. Fused thorax, $0.7 \mathrm{~mm}$. long, $0.55 \mathrm{~mm}$. wide. Egg-strings, $0.45 \mathrm{~mm}$. long, $0.15 \mathrm{~mm}$. wide. 
(uncatus, bent inward or curved like an anchor, alluding to the egg-cases.)

During the observation of these specimens while still alive it was noted that the usual peristaltic movements of the stomach and intestine were assisted by the drawing forward and backward of the oviduct on either side alternately. This movement was rhythmic and each oviduct was pulled nearly to the narrow neck between the head and first thorax segment.

The species can be told readily by the comparatively large size and small number of eggs and by the peculiar position of the egg-strings. In no other known species are they any more than divergent and pointing backward; here they actually point forward.

\section{HATSCHEKIA INSOLITA, new species.}

Plate 42, figs. 227-232.

Host and record of specimens.-Twenty females belonging to this species were obtained from the gills of the rock hind, Epinephelus adscensionis, during the summer. There were never more than one or two on a single fish, sometimes alone, sometimes in company with the preceding species (uncata). The present species was in full view while uncata was hidden between the filaments.

Type-specimen.-Cat. No. 43549, U.S.N.M. Paratypes, Cat. No. 42336, U.S.N.M.

Female.-Body of medium length and rather wide; carapace large and nearly circular, but with an irregular outline, and about one-third the entire length; dorsal median rib or keel of the carapace well developed. 'First and second thorax segments forming a short neck joining the carapace with the rest of the segments. Fused thorax clubshaped, one-half longer than wide, with the segmentation clearly indicated on the lateral margins; fifth segment with posterior lobes each as broad as the fused sixth segment and abdomen and reaching back farther than the latter. Fused sixth segment and abdomen only onesixth the width of the fourth segment, hemispherical, and slightly contracted where it joins the fifth segment. Anal laminæ long and narrow, apparently two-jointed, the terminal joint tipped with three setæ.

Egg-cases club-shaped, from two-thirds to three-quarters the length of the body and taken together as wide as the fifth segment; eggs of large size, from four to seven in each case.

First antennæ long and narrow, about the same diameter throughout and poorly armed with spines. Second pair with a stout basal joint which is a little longer than the entire first antenna and armed with strong muscles. Terminal claw weak, abruptly narrowed to less than one-fifth the diameter of the basal joint, bent sharply at a right angle close to the base, and tapered to a fine needle point. In fact, 
it is just the opposite in every particular of what would be expected on such a long and powerful basal joint. Mouth tube elliptical in outline with a squarely truncated tip, one-half longer than wide.

Maxillæ distinctly showing as papillæ on either side of the mouth tube, each tipped with three setæ very similar to those of the Ergasilidæ. Swimming legs with long and narrow basal joints, the proximal joint of the exopod longer than the one-jointed endopod. Third legs present as minute papillæ on the lateral margins, each tipped with two spines; fourth legs indicated by a pair of single spines, also on the lateral margins.

Color a uniform translucent yellowish-white, the eggs in the oviducts a light brown, those in the external sacks a dark seal-brown.

Total length, $0.85 \mathrm{~mm}$. Carapace, $0.28 \mathrm{~mm}$. long and wide. Fused thorax, $0.55 \mathrm{~mm}$. long, $0.37 \mathrm{~mm}$. wide. Egg-strings, $0.45 \mathrm{~mm}$. long, $0.12 \mathrm{~mm}$. wide at the distal end.

(insolitus, unusual, alluding to the second antennæ and the rudimentary third and fourth legs.)

Although found upon the same host as the preceding species, the present form is readily distinguished by the length of the second antennæ and the peculiar shape of their terminal claw and by the presence of the rudiments of the third and fourth pairs of legs in the sinuses on the lateral margins. In this last respect it resembles Hatschekia (Clavella) labracis Van Beneden.

\section{HATSCHEKIA LINEARIS, new species.}

Plate 44, figs. 240-246.

Host and record of specimens.-Ten females were obtained from the gills of the red-mouthed grunt, Bathystoma rimator, July 14, 1910. They were attached with their long axis parallel to the filament and on its outer surface.

Type-specimen.-Cat. No. 43551, U.S.N.M. Paratypes, Cat. No. 42293, U.S.N.M.

Female.-General body form linear, seven times as long as wide, and made up of four distinctly separated parts: the head; the first and second thorax segments partially fused; the third, fourth, and fifth segments completely fused; and the sixth segment and abdomen also completely fused. Carapace very small and circular, only one-ninth of the entire length, and a little narrower than the posterior body, with regular outlines; first and second antennæ entirely concealed in dorsal view. First and second thorax segments longer than the head, a little narrower anteriorly, but much widened posteriorly through the bases of the second legs. Fused third, fourth, and fifth segments linear, five times as long as wide and tapering slightly posteriorly, with nearly straight sides; third segment contracted into a narrow neck anteriorly where it joins the second segment, leaving the second 
legs visible dorsally. Fifth segment forming a short and blunt lobe on either side of the genital segment posteriorly, the tip of the lobe just reaching the posterior margin of the opening of the oviduct. Fused sixth segment and abdomen semielliptical, about the same length and width, which is one-third that of the fifth segment. Anal laminæ minute and widely separated, each tipped with three setæ.

Egg-strings half the entire length, and half the width of the fifth segment, about twenty eggs in each string.

First antennæ short, their basal joints fused into a sort of rostrum, projecting from the center of the anterior margin, but curved over ventrally so as to be concealed beneath the carapace. They are apparently made up of only three joints, the terminal of which carries all the spines. Second antennæ with a stout and strongly curved terminal claw, half the length of the basal joint. Mouth tube wide and very bluntly rounded at the tip so as to be nearly circular in ventral outline. The two terminal joints of the maxillipeds are longer than the stout basal joint, and are tipped with a curved claw, which has an accessory spine at the center of its inner margin. There is also a short curved spine projecting from the top of a small papilla on the ventral surface of the head between the base of the maxilliped and the midline. This is not the rudiment of the maxilla since it is behind the chitin rib which supports the maxilliped.

Swimming legs with two-jointed exopods and one-jointed endopods, and with a stout spine on the basal joint inside of the endopod. Both rami of the first pair are tipped with four spines; the exopod of the second pair has two, the endopod three.

The ovaries and oviducts extend the entire length of the third, fourth, and fifth thorax segments; the maturing eggs are orange-brown in color; the cement glands are close to the midline inside of the oviducts, and are one-fourth the length of the latter, with a short glandular portion.

Color of the head yellowish-gray, translucent; free thorax brownishyellow; genital segment a deeper brown; oviducts and egg-strings medium orange-brown; lateral margins of the free thorax and genital segment with an olive-green tinge; central line over the intestine yellow, bordered with orange. In many specimens the muscles of the head and free thorax are deep red, showing prominently through the translucent carapace and dorsal epidermis.

Total length, $2.33 \mathrm{~mm}$. Carapace, $0.26 \mathrm{~mm}$. long and wide. First and second thorax segments, $0.33 \mathrm{~mm}$. long, $0.39 \mathrm{~mm}$. wide. Third, fourth, and fifth segments, $1.75 \mathrm{~mm}$. long, $0.33 \mathrm{~mm}$. wide. Eggstrings, $1.2 \mathrm{~mm}$. long.

(linearis, narrow, thread-like.)

This species is radically different from all the others that have been obtained in several particulars. The most striking peculiarity is the 
separation of the two leg-bearing thorax segments. In most other species these are more or less fused with the three following segments to form the so-called "body" of the copepod. Here they are entirely separated and the species may be recognized by this separation at a glance.

If any essential differences could be found in the appendages, such a separation would warrant the establishment of a new genus, but as the appendages are in every way similar to those in all Hatschekia species, it seems best to locate this new form in that genus. Another difference is the long distance between the mouth parts and the first swimming legs. Usually these first legs are so close to the maxillipeds that they are often partially concealed beneath the latter. Here there is a wide interval between the two.

The species is quite common, nearly every fish yielding specimens, but it is not at all numerous, as only two or three specimens could be found on any one fish, and the most careful search of many fish failed to reveal a single male. In the separation of the two leg-bearing segments and in the relative position of the mouth parts and first legs Hatschekia (Clavella) tenuis Heller closely resembles the present species, but the two differ radically in the relative proportions of the different parts of the body, as well as in the size and structure of the antennæ and mouth parts.

HATSCHEKIA IRIDESCENS, new species.

Plate 41, figs. 216-221; plate 44, fig. 247; plate 45.

Host and record of specimens.-About 50 females and 2 males were obtained from the gills of a porcupine fish, Diodon hystrix, 15 inches in length. The females were attached between the gill filaments, the great majority of them with their heads toward the base of the filaments, and all with their bodies parallel with the filaments. The males were attached to the tips of the filaments, and not at all securely.

Type-specimen.-A female, Cat. No. 43550, U.S.N.M. Paratypes, Cat. No. 42325, U.S.N.M.

Female.-Body short and of medium width; carapace very large, one-third of the entire length, semielliptical, three-fifths wider than long, the lateral and posterior margins a nearly even curve, the anterior margin four-lobed, a narrow lobe on either side of the median line, with a much wider one outside of it extending to the lateral margin. Dorsal surface with a median longitudinal keel extending its entire length, the strong muscles operating the second antennæ and mouth parts attached to it and showing as diagonal lines on either side of it.

Fused thorax elongate-ovate, one-half longer than wide, a little narrower than the carapace, with only the anterior segments indicated by lateral indentations. The two leg-bearing segments fused with 
the others, the fifth segment forming a wide lobe on either side of the genital segment and abdomen, and extending a little beyond the posterior margin of the latter. Fused genital segment and abdomen semielliptical, one-sixth of the width of the third segment, one-half wider than long, with a nearly straight posterior margin; anal laminæ elliptical, a little longer than wide, each tipped with three setæ of equal length.

Egg-strings five-ninths of the body length, one-fourth as wide as long, each containing eight or nine large eggs.

First antennæ five-jointed, the joints diminishing regularly in size outwards and well armed with setæ and spines. Terminal claw of the second pair fully as long as the basal joint, bent at a right angle near the tip and with a swelling on the inner margin near the base. Mouth tube conical, widest near the base and tapering to a rather sharp tip; maxillæ simple pimples without setæ or spines; maxillipeds of the usual pattern, the two terminal joints about the same length as the much stouter basal joint. Exopods of the swimming legs two-jointed, endopods one-jointed, a slender spine outside the base of the exopods, the other spines as shown in the drawings.

Cement glands close to the median line, the glandular portion about half the entire length and showing no trace of segmentation. Semen receptacle a long median bag lying between the ducts of the cement glands, divided posteriorly, with a duct extending nearly at right angles to the long axis of the bag and opening close to the external orifice of each oviduct. In figure 255 a spermatophore may be seen with its long duct attached to this opening. Evidently the ducts of these spermatophores are not crossed as in some of the other copepods.

Color a translucent orange-yellow, deeper on the appendages and along the midline; oviducts dark cinnamon-brown; eggs in the external cases also dark brown, increasing in intensity with development.

Total length, $2.75 \mathrm{~mm}$. Carapace, $1.33 \mathrm{~mm}$. wide, $1 \mathrm{~mm}$. long. Fused thorax, $2 \mathrm{~mm}$. long, $1.28 \mathrm{~mm}$. wide. Egg-strings, $1.75 \mathrm{~mm}$. long, $0.33 \mathrm{~mm}$. wide.

Male.-Body proportionally longer and narrower than that of the female; carapace nearly circular in general outline, but projecting a little anteriorly on the midline and reentrant posteriorly leaving a well-defined lateral lobe on either side. Near the center of the carapace a small eye can be seen on either side of the midline with a central mass fusing them together.

Fused thorax nearly three times as long as wide, with the segmentation clearly indicated along the lateral margins, even the first and second segments being separated by a deep marginal indentation. 
Genital segment fused with the others and produced posteriorly into a short and blunt lobe on either side.

Abdomen one-jointed, one-third the width of the fused thorax, and enlarged a little posteriorly; anal laminæ large, three times as long as wide, one-half longer than the abdomen, each tipped with two large and stout spines, the inner of which is as long as the lamina itself. Appendages like those of the female, but longer and more slender. First antennæ carried at right angles to the body axis, and projecting more than half their length beyond the lateral margins of the carapace. Maxillipeds also projecting obliquely backward, with their entire length visible in dorsal view. First two pairs of swimming legs with two-jointed exopods and one-jointed endopods; there is also a rudimentary third pair of legs behind the second pair on the lateral margins; each consists of a single short joint tipped with two spines.

Total length, $1 \mathrm{~mm}$. Carapace, $0.3 \mathrm{~mm}$. long and wide. Fused thorax, $0.6 \mathrm{~mm}$. long, $0.22 \mathrm{~mm}$. wide.

Color like that of the female except that the brown oviducts are replaced by yellow sperm receptacles.

Nauplius.-Body elliptical, one-half longer than wide, with a regular curve; a narrow papilla-like protuberance at the center of the anterior margin, and a much wider one between the balancers, posteriorly. There are the usual nauplius appendages, the exopods of the second antennæ and mandibles carrying only four rowing setæ. Balancers slender and cylindrical, carried straight backward parallel with the body axis, each of them slightly convex inward. Body with three large masses of brown pigment, one triangular in shape, in the center of the anterior portion, the other two along each lateral margin, meeting posteriorly. Between and in front of these pigment masses the body is translucent and shows the usual diagonal muscles (see fig. 216).

Total length, $0.2 \mathrm{~mm}$; width, $0.11 \mathrm{~mm}$.

(iridescens, iridescent, alluding particularly to the fully developed egg-strings.)

The burial of the large second antennæ of this species in the tissue of the gill filament of its host produces a sort of tumor or swelling, similar to that produced on the fins by the maxillipeds of Tucca impressus. But these parasites are not thereby anchored to one spot as is the case with Tucca; they are able to loosen their hold and move up and down the filaments by a walking motion of the second antennæ. Some of them free themselves entirely and wriggle off the gills on to the bottom of the aquarium, when the gills are removed from the fish and put in water. The females live a long time, lying on their backs and wriggling about violently, but they are unable to 
swim at all. The males can swim readily but die much sooner than the females. Many of the egg-strings were ready to hatch and active nauplii were obtained, but none of them could be carried through even the first molt. In the matured egg-strings they show through the walls of the external cases with a peculiar iridescence, totally unlike anything seen in other copepods, and this has suggested the specific name for the new species.

\section{Family LERNAID无.}

\section{PENNELLA EXOCGTI (Holten).}

Lernæopenna blainvillii Lesueur, 1824, p. 289, pl. 11, figs. 2e-k.

Host and record of specimens.-This species was originally described by Holten in 1802 under the name Lernæa exocœti, and was obtained from the common flying fish, Exoccetus volitans, in the Atlantic Ocean. It was afterwards taken by Lesueur from the same host in the vicinity of the West Indies, and described and figured under the name Lernæopenna blainvillii. Lesueur found a second specimen, on the same fish and close to the one just mentioned, but so different from it that he was at a loss just where to place it; he suggested that the two might be different sexes of the same species (1824, p. 292). This second specimen Milne Edwards made the type species of his new genus Lernæonema (1840, p. 524), but Richiardi has suggested (1877, p. 199) with greater probability that it is an undeveloped $P$. exocœti.

\section{THERODAMAS SERRANI Krøyer.}

Therodamas serrani KR $\varnothing$ Yer, 1863, p. 316, pl. 15, figs. $4 a-f$.

Host and record of specimens.-Krøyer obtained a tolerably large number of females of this Lernæid from the gills of a Serranus species in the Danish West Indies. He established for them (1863, p. 316) a new genus and species which seem to be well founded, but no other investigator has ever obtained any specimens. This is the more to be regretted because the parasite is very peculiar in many respects, but although all the species of Serranus as well as other groupers were carefully examined, nothing of the sort could be found at Jamaica.

\section{LERNAEOLOPHUS HEMIRAMPHI (Krøyer).}

Lernæa hemiramphi KRфYeR, 1863, p. 318, pl. 15, figs. $7 a-f$.

Host and record of specimens.-A single specimen of this species was obtained from the mouth opening of a Hemiramphus, species, probably $H$. brasiliensis, from the Danish West Indies. Upon this specimen Krøyer established his new species (1863, p. 318), and so far as can be judged it seems perfectly valid. 
Plate 46.

Host and record of specimens.-Four females, one of which was a young developmental stage, were obtained from the gill arches of the blue parrot fish, Scarus cæruleus, June 30, 1910. Three of these were found upon a single fish, and were close together in the floor of the throat, where the gill arches join.

Type-specimen.-Cat. No. 43557, U.S.N.M. Paratypes, Cat. No. 42292, U.S.N.M.

Female.-General body form slender, the head nearly spherical and about twice the diameter of the neck, the posterior body clubshaped but not much enlarged, the abdomen narrowed to half the diameter of the genital segment. Body also bent into a half circle so that the genital segment and abdomen point forward toward the head. In fully matured specimens the abdomen is covered with a dense growth of dichotomous processes.

Head flattened a little dorso-ventrally, and armed on its dorsal surface with three chitin horns, all at right angles to the body axis and dichotomously branched. The two lateral horns are considerably larger than the posterior one, their length being three or fow times the diameter of the head, and are three times compounded. The posterior horn is much shorter, its length only once and a half times the diameter of the head, and is only twice compounded. Usually one or the other lateral horn is enlarged at the base, and the branches of all the horns taper regularly toward the tips.

There is hardly a trace of the two small knobs on the top of the head, which represent the first antennæ in $L$. sultanus.

On the flattened ventral surface, or face of the head, may be found the second antennæ and mouth parts. The former are in the shape of short and stumpy processes along what may be called the forehead of the parasite and down either side of the face. Each consists of two parts which evidently belong together and which are united in early development, but become more or less separated later. Behind these on the lower sides of the face and along the chin are the maxillipeds, also represented by stumpy processes, flattened and irregular, and showing more or less tendency to become bipartite. The space between the second antennæ and maxillipeds is hollowed out into a shallow cup, in the bottom of which are three small spherical knobs of about the same size, one posterior on the median line, and in front of this a pair, one on either side of the median line. The former is the rudiment of the under lip, the latter of the mandibles.

In front of the mandibles in some of the specimens may be seen a slight elevation on the median line which represents the last traces of the upper lip. In the developmental stage the upper and under 
lips are prolonged and loosely united into a sort of proboscis, and the mandibles form swellings at its sides.

Just behind the head are four pairs of rudimentary legs, so close together that they overlap for two-thirds of their length. Each leg consists of a broad triangular lamina, representing the basal joint, and two tiny spines, representing the rami. In the developmental stage they stand out nearly at right angles to the ventral surface, in the adult they are tightly appressed to that surface. The first four (leg-bearing) thorax segments are narrow and neck-like and very short; the fifth segment is of the same width and greatly elongated, and forms the bulk of the so-called neck; the genital segment is enlarged to two or three times the diameter of the neck, varying considerably in different individuals. It is impossible in this species to locate accurately the dividing line between the fifth and genital segments, but judging from the following species the point where the enlargement begins is the line of demarcation.

At about the center of the enlarged genital segment the body is bent abruptly so that the abdomen points toward the head.

In the developmental stages the curve is broad and there is but little twisting of the body; in the mature adult the curve becomes so sharp that the dorsal surface of the abdomen is brought almost into actual contact with the side of the fifth segment. At the same time, the posterior portion of the body is twisted to the right or left, so that the legs and mouth-parts appear to be on one of the lateral surfaces.

The abdomen is long and slender, and tapers gradually from base to tip; at the base it is about half the diameter of the genital segment, and on a level with the dorsal surface of the latter. It shows no external signs of segmentation. On the sides of the genital segment at the posterior end are two pairs of dichotomously branched processes, and along the lateral margins of the abdomen are seven or eight additional pairs. At first these are short and simple and do not conceal the surrounding parts, but they increase in size and complexity with age, and finally cover and conceal the abdomen, egg-strings, and posterior portion of the genital segment.

The egg-strings are scarcely wider than one of the processes, but are from one and a half to two times the length of the body. Each is tightly and irregularly coiled into a small mass, entirely surrounded by the processes, and in this way supported and protected.

Color of the entire body blood- or wine-red, even to the tips of the horns; dichotomous processes pale yellow-gray or straw-color; eggstrings snow-white.

Total length, $20 \mathrm{~mm}$. Length of horns, $5 \mathrm{~mm}$.; of processes, 6 $\mathrm{mm}$. Diameter of head, $2.8 \mathrm{~mm}$.; of neck, $1 \mathrm{~mm}$.; of genital segment, $2.8 \mathrm{~mm}$. 
(recurvus, bent back, alluding to the posterior portion of the body.)

In 1840 Milne Edwards very briefly described what he called a new species of Pennella, $P$. sultana. In 1864 Nordmann figured and described a new variety of the same species, $P$. sultana sigmoidea. In 1865 Heller established the new genus Lernæolophus upon some specimens which he identified as identical with those described by Milne Edwards.

No one of the three descriptions, nor even all of them together, are very complete, especially with regard to the mouth parts, but enough is shown to fully establish the validity of the genus.

Milne Edwards does not even mention the mouth parts; Nordmann shows a series of 11 small papillæ arranged in the shape of an ellipse, the anterior one unpaired on the midline, the others more or less regularly paired. Heller claimed to distinguish a pair of antennæ on the front of the head, and around the mouth one pair of "palps" and two pairs of "maxillipeds." These last three pairs of appendages he described as being armed with terminal "claw-joints," and the second maxillipeds as being distinctly three-jointed. He makes no mention of the small papillæ in the bottom of the mouth depression, nor does his figure show them. If they were present the total number would be the same as that given by Nordmann, but the arrangement would be radically different. If there really were three pairs of claws around the mouth, they must have represented the second antennæ, a pair of maxillæ, and a pair of maxillipeds. In the present species, however, there are no traces of any claws, and the two anterior pairs of papillæ that look like separate appendages in the adult, are certainly parts of the same single pair in the developmental stage. This would indicate that the maxillæ are entirely lacking, as in other genera belonging to this family.

The present species is sufficiently distinguished from sultanus by the comparatively smaller size of the head, by the branching of the posterior horn, by the fact that the body is bent only once and then very sharply, instead of into a broad sigmoid curve, and by the overlapping of the four pairs of legs. Also if Heller's description of the mouth parts is correct, they are much better developed in sultanus than in recurvus.

The fact that no satisfactory description has ever been given of any species of the genus is sufficient warrant, for the present somewhat detailed one.

LERNACOLOPHUS STRIATUS, new species.

Plate 47, figs. 260, 261.

Host and record of specimens.-Two females were obtained from the throat of the barracuda, Sphyræna barracuda, July 15, 1910. They were fastened to the floor of the throat, just inside the lower lip. The 
head was buried close to the ventral aorta, while the body trailed back along the gill arches, The better specimen of the two has been made the type.

Type-specimen.-Cat. No. 42320, U.S.N.M.

Female.-General body form slightly curved and slender; diameter almost uniform throughout, only slightly enlarged posteriorly. Horns long and slender and profusely branched; posterior processes all pointed backward, crowded together, and unbranched.

The dividing line between the fifth and sixth (genital) segments is clearly indicated by a transverse groove and also by a marked change in color. This groove is situated at the beginning of the posterior enlargement of the body, and the color changes from wine-red to a dull white. Head flattened more than in recurvus and projecting much farther in front of the base of the horns. Lateral horns four times compounded; posterior horn not at right angles to the body axis, but pointing diagonally backward, almost parallel with the thorax, and three times compounded. Sides of the head fluted or wrinkled, the wrinkles extending around to the bases of the second antennæ and mouth parts on the front of the head. First antennæ practically wanting, only the merest vestiges of knobs being left; second antennæ and mouth parts similar to those of recurvus, but with these differences. The knobs representing all the appendages are relatively larger; the maxillipeds are much more irregular and are fully twice the size of the second antennæ, and there is much less space between the two at the sides of the head. The mouth depression is shallower, but the form, size, and arrangement of the three small knobs is almost exactly the same.

The swimming legs are smaller than in recurvus, not as distinctly triangular, and they have no spines; they are also farther apart so that they do not even touch one another. The genital segment is not recurved, but is bent only slightly out of a straight line. The egg-tubes are coiled into tight bundles, entirely concealed by the posterior processes; each, if straightened out, would be about one and a half times the length of the body.

Total length, $27 \mathrm{~mm}$. Length of horns, $7.5 \mathrm{~mm}$.; of posterior processes, $6.5 \mathrm{~mm}$. Diameter of head, $2.7 \mathrm{~mm}$.; of neck, $1.6 \mathrm{~mm}$.; of genital segment, $2.6 \mathrm{~mm}$.

Color of the anterior body and horns a pale wine-red, of the genital segment a dull white, of the appendages a pale yellow.

(strialus, fluted or grooved, alluding to the sides of the head.)

This species is readily distinguished by the fluted head, large second antennæ and mouth parts, straight body, and posteriorly pointing and unbranched processes. 


\section{Family LERNÆOPODIDÆ.}

\section{Genus THYSANOTE Krфyer.}

THYSANOTE POMACANTHI Kroyer.

Thysanote pomacanthi KR $\varnothing$ YER, 1863, p. 288, pl. 15, figs. $1 a-i$.

Host and record of specimens.-Krøyer obtained half a score of specimens from the gills of the Indian or flat-fish, Pomacanthus paru, from the Danish West Indies. Upon these he established the new genus, Thysanote, and the new species, pomacanthi, which became the type of the genus.

Two years later Heller said (1865, p. 238) that Krøyer's genus was nothing but a "Brachiella" with numerous processes on the arms and posterior body, and he described two new species which he referred to the genus Brachiella. But neither Krøyer nor Heller found the males of the species they described. Nordmann, however, had previously described and figured (1832, p. 92, pl. 8, figs. 1 to 3) both sexes of "Brachiella impudica," which have since been referred to the genus Thysanote by Bassett-Smith (1899, p. 497), T. Scott (1900, p. 169), and A. Scott (1904, p. 123).

Steenstrup and Lütken also described and figured (1861, p. 419, pl. 15, fig. 35) both sexes of "Brachiella appendiculata," which evidently belongs to this genus Thysanote, and Bassett-Smith described and figured (1898, p. 14, pl. 6, figs. 1 to 3) both sexes of "Brachiella appendiculosa," which he afterwards acknowledged (1899, p. 497) to be identical with Steenstrup and Lütken's species.

These last two males correspond with the one here described, as do the females, and may therefore be taken as typical of the genus.

There are far more differences between the males and those of true Brachiella species than there are between the females, but even with the latter the differences are enough to establish the validity of the genus. There is no one thing besides the fimbriate processes which can be regarded as a conclusive generic character. Rather is the genus distinguished by an accumulation of small and not very prominent differences, which may be summed up as follows:

Female.-Cephalothorax short and thickset, and in the same line with the rest of the body; completely fused with the remainder of the thorax or only imperfectly separated; segmentation indicated by breaks in the musculature. The arms (second maxillæ) and posterior margin or corners of the body bearing fimbriate processes; no abdomen, anal laminæ very rudimentary.

First antennæ between the terminal joints of the second pair and the mouth, visible only from below, indistinctly segmented. Second pair closely appressed to the frontal margin of the head and just meeting at the midline; mandibles with a pronounced curve near the center of the blade; first maxillæ large, with a distinct palp; 
second maxillæ sometimes longer than the cephalothorax, united only at the tip; maxillipeds with a powerful basal joint and a short terminal claw.

Male.-Body short and thickset; cephalothorax more or less completely separated from the posterior unsegmented portion; the latter terminated by two conical anal laminæ. Appendages on the ventral surface at right angles to the body axis; second antennæ uncinate; second maxillæ with stout sickle-shaped claws; terminal portion of the maxillipeds twisted like a corkscrew.

THYSANOTE LONGIMANA, new species.

Plate 47, figs. 262-264; plate 48.

Host and record of specimens.-Five females and three males were obtained from the outside of the throat of the red snapper, Neomænis aya, July 23, 1910.

Type-specimen.-A female, Cat. No. 43552, U.S.N.M. Paratypes, Cat. No. 42281, U.S.N.M.

Female.-General body form elongate, widest posteriorly; divided into two regions, the cephalothorax and the fused thorax and abdomen. Cephalothorax oblong, one-third of the entire length, bluntly rounded anteriorly, and enlarged posteriorly through the bases of the second maxillæ. Body inversely club-shaped, with a smooth surface and evenly rounded outlines, the only trace of segmentation being found in the interruption of the longitudinal muscles which run along the midline on both the dorsal and ventral surfaces. There are three of these muscle breaks, making four segments, the last of which is a fusion of the fifth and sixth (genital) segments, and the abdomen. The egg-tubes are attached to the posterior margin of this fused segment, nearer the dorsal than the ventral surface; they are cylindrical in form and about two-thirds of the entire length. The eggs are rather small and are arranged in five or six longitudinal rows, from 25 to 30 eggs in each row. There are eight of the branched processes which characterize the genus; the first pair are attached to the arms about one-third of their length from the base; the second pair are attached to the arms where the latter join the body, so that in some specimens they seem to come from the sides of the body; the third and fourth pairs are close together at the posterior corners of the last (fused) body segment. The branching is dichotomous, and none of the rami are divided more than once or twice, making the processes comparatively simple.

Between the egg-tubes, on either side of the anus, and on a level with the ventral surface, is a short, finger-like process.

First antennæ imperfectly segmented and tipped with a pair of very short spines, but without any other armature. Owing to the $69077^{\circ}$-Proc.N.M.vol.44-13-17 
pushing forward and curving inward of the second antennæ, this first pair comes to lie between the second pair and the mouth tube, and can be seen only from the ventral surface (fig. 267).

In consequence of this abortive position they have been frequently mistaken for other appendages. Second antennæ of the usual biramose form, bent across the anterior margin of the head at right angles to the body axis, with their tips just meeting on the midline above the mouth tube. Exopod broad, one-jointed, and bluntly rounded; endopod two-jointed, much narrower, and tipped with two spines. Mandibles mounted on a prominent and powerful basal joint, just outside the base of the mouth tube; blade curved near the center and armed with teeth of two sizes, about 12 in all.

First maxillæ large and stout, bipartite at the tip, each ramus ending in a single stout spine; palp on the inner, ventral surface, just below the rami, short and tipped with two spines.

Second maxillæ or arms one-half longer than the cephalothorax, joined only at the tips, where is formed a short but strong mushroom bulla.

No swimming legs visible anywhere upon the body. In the ripe female the entire body behind the cephalothorax is filled with the small eggs.

Color a uniform yellowish-white, without pigment.

Total length, $8 \mathrm{~mm}$. Cephalothorax, $2.2 \mathrm{~mm}$. long, $1.2 \mathrm{~mm}$. wide. Posterior body, $6.8 \mathrm{~mm}$. long, $2.2 \mathrm{~mm}$. wide. Egg-tubes, $4 \mathrm{~mm}$. long.

(longimana, longus, long, and manus, hand, alluding to the length of the arms or second maxillæ.)

Male.-General body form spindle-shaped and rather thickset; divided into two regions by a well-defined groove. Cephalothorax in the form of half a short cone, covered with a carapace which projects anteriorly and along the sides over the bases of the appendages. Thorax-abdomen a long and bluntly rounded cone, twice the length of the anterior one and not as wide, ending posteriorly in a pair of narrow conical anal laminæ.

First antennæ attached to the sides of the carapace some little distance back of the anterior end, indistinctly jointed and tipped with two tiny spines. Second antennæ close behind the first, with a biramose tip, the exopod of which ends in a sickle-shaped claw.

First maxillæ between the base of the antennæ and the mouth tube, projecting considerably beyond the tip of the latter; the two terminal spines and palp like those of the female. Second maxillæ short and stout and pointed forward, the terminal claw also short and stout, sickle-shaped, with its point almost in contact with the end of the basal joint.

Maxillipeds long and rather slender and pointed backward; second joint and terminal claw bent into a sort of corkscrew, which with its fellow is ordinarily concealed between the two maxillipeds. 
Color yellowish-brown, considerably darker than the female.

Total length, $1.35 \mathrm{~mm}$. Greatest width, $0.5 \mathrm{~mm}$.

CLAVELLA (ANCHORELLA) LACINIATA Krøyer.

Plate 49.

Anchorella laciniata KR $\emptyset \mathrm{YER}, 1863$, p. 308, pl. 16, figs. $8 a$ and $b$.

Host and record of specimens-Krøyer obtained two females from the gills of a fish which he designated as "Acanthurus chirurgus," but which is now known as Teuthis hepatus, the doctor fish, from the Danish West Indies. Upon these he founded a new species of the genus Clavella (Anchorella), which he named A. laciniata.

During the season of 1910 five females and two males were found attached to the skin in the roof of the mouth of the same host at Montego Bay, Jamaica. Cat. No. 42310, U.S.N.M.

Female.-General body form short and plump; cephalothorax longer than the posterior body and nearly reaching the ends of the egg-strings, flexed backward against the dorsal body surface, and of the same diameter throughout. Not only are the arms entirely lacking but the attachment bulla is even placed at the bottom of a pit, below the level of the body surface. Posterior body bell-shaped, the apex and one side of the bell fastened to the cephalothorax, the margin laciniate or cut into conical processes, six in number, two posterior, two lateral, and two anterior, while the mouth of the bell, between the bases of the processes, is covered by the posterior body wall. The anterior and posterior processes are about equal in size, and are one-third the length of the posterior body; the lateral processes are much smaller.

Abdomen, situated in the angle between the two posterior processes, minute and nearly spherical. Egg-cases ellipsoidal, half the length and width of the posterior body, and attached to the flattened surface between the bases of all the processes; eggs large, arranged in five or six rows, about 10 in each row.

First antennæ conical, distinctly three-jointed, the last joint tipped with two spines, the others unarmed. Second antennæ closely appressed to the anterior margin and bipartite at the tip, the inner ramus two-jointed and ending in a claw, the outer one one-jointed and unarmed. Proboscis a broad cone, projecting prominently from the ventral surface of the head.

First maxillæ ending in two long spines; palp minute, one-jointed, attached to the inner margin close to the distal end.

Maxillipeds with a swollen triangular basal joint, and a slender, nearly straight terminal claw. The latter is attached to the side rather than the tip of the basal joint, and carries an accessory spine on its inner margin toward the tip. Near the center of the inner mar- 
gin of the basal joint is a papilla which carries a long seta; just below this are two rounded knobs covered with short spines.

Color a dark yellowish-white, turning to lavender and then purple on the posterior processes and the dorsal surface.

Total length, $4.4 \mathrm{~mm}$. Cephalothorax, $2.5 \mathrm{~mm}$. long, $0.55 \mathrm{~mm}$. wide. Posterior body, $1.45 \mathrm{~mm}$. wide at the posterior end, $3 \mathrm{~mm}$. long, including the posterior processes which are $1 \mathrm{~mm}$. long. Eggcases $1.3 \mathrm{~mm}$. long, $0.65 \mathrm{~mm}$. wide.

Male.-General body form that of a typical Clavella male, ovate, flattened laterally, a little pointed anteriorly, abruptly rounded, and considerably abbreviated posteriorly, without any trace of regions or segments. The entire dorsal surface is covered with a carapace, which projects a little over the anterior margin, forms a distinct ridge along the sides of the body, and fades away imperceptibly posteriorly.

First antennæ three-jointed and considerably enlarged at the base; second pair flattened and laminate, projecting at right angles to the edge of the carapace, about the same length as the first pair, the outer, terminal ramus cut off diagonally.

First maxillæ like those of the female; second pair ending in stout curved claws; maxillipeds with a strongly swollen basal joint, having on its ventral margin a tooth-like projection with which the tip of the terminal claw interlocks.

Color a creamy yellow, uniform all over the body.

Total length, $0.5 \mathrm{~mm}$. Greatest width, $0.33 \mathrm{~mm}$.

Nauplius larva.-General structure the same as that in the other Lernæopodidæ. Body a flattened ellipsoid, the two diameters in the proportion of 3 to 4 , the margins evenly rounded. Frontal gland very large and situated far forward near the anterior margin; no other internal structures visible except the muscles which move the appendages. Of these latter there are only two pairs, corresponding to the first and second antennæ. The first pair are one-jointed, uniramose, and tipped with two long setæ; the second pair are biramose, the exopod five-jointed, each joint terminating in a long seta, the endopod two-jointed, and terminating in two setæ. At the posterior end of the body there are no balancers, but instead a large rounded knob. made up of the fused thorax and abdomen.

The entire body is uncolored except six isolated patches of dark lavender or purple pigment. The first two pairs are situated on either side of and close to the eye, the remaining and largest pair at the posterior corners of the body.

(laciniata, cut into deep and irregular lobes, alluding to the posterior processes.)

This species was briefly described and figured by Krøyer in 1863 (p. 308, pl. 16, fig. $8 a$ to $b$ ), and has never been seen by subsequent 
investigators. Krøyer's description lacks practically all the details with reference to the appendages and his figures are so small that nothing can be learned from them about the appendages. Accordingly the species has been redescribed, the details of structure have been added, and the male and nauplius larva have been presented for the first time.

This male proves to be a typical Clavella (Anchorella) form, so that Krøyer located the species correctly in spite of the presence of three pairs of posterior processes around the egg-strings that might have suggested a relationship to Brachiella.

The nauplius larva was dissected out of the egg-strings and compares closely with that obtained in a similar manner from the eggstrings of Achtheres ambloplitis. ${ }^{1}$

The species may be recognized by the bell-shaped posterior body, with the conical processes around its flaring mouth, and the short and thickset egg-cases protruding from the latter like a pair of tongues or clappers.

CLAVELLA INVERSA, new species.

Plate 50.

Host and record of specimens.-Six females were obtained from the gills of the red-mouthed grunt, Bathystoma rimator, July 18, 1910.

Type-specimen.-Cat. No. 43513, U.S.N.M. Paratypes, Cat. No. 42291, U.S.N.M.

Female.-General body form short and very thickset. Cephalothorax flexed backward so that it is in the same line with the arms and at right angles to the rest of the body. Head club-shaped, its diameter a little less than that of the neck, its anterior margin squarely truncated, with the proboscis and first antennæ projecting. slightly. At the junction of the neck with the posterior body, which is also the point from whence arise the arms or second maxillæ, there is present on each lateral margin and nearer the dorsal than the ventral surface a large kidney-shaped knob. These knobs are very conspicuous in both living and preserved specimens and furnish a ready means of recognizing the species. So far as is known, nothing of this sort has ever been observed in any other species of the genus. The knobs are covered with the outer skin so thickly that their presence is indicated merely by a wrinkled swelling, but, the skin being transparent, they are perfectly visible inside the swelling. They appear to be the maxillary glands, crowded out of their normal position in the second maxillæ, for ducts may be seen on their dorsal surface leading inward and upward and opening at the base of the second maxillæ. The latter are short and completely fused, except the internal muscles, which still indicate their double origin. The attachment bulla is large, saucershaped, and sessile, with the stem entirely lacking. 
The posterior body is transversely elliptical, a trifle wider than long, with a strongly convex ventral surface and an equally concave dorsal surface. At the center of the posterior margin, on a level with the ventral surface, is the tiny abdomen, which is short, obovate, and strongly flattened dorso-ventrally.

The egg-strings are ellipsoidal, each three-fourths as long as the posterior body and half as wide; the eggs are very large and are arranged in six or seven rows, about five in a row.

First antennæ three-jointed, the two terminal joints slender, tipped with two short spines, and projecting well beyond the anterior margin of the head, the basal joint swollen and armed with a single spine on the inner margin near the distal end. Second antennæ flexed at a right angle and appressed close to the anterior margin of the head, their tips meeting at the midline. Proboscis broadly conical, its tip reaching a little beyond the frontal margin. First maxillæ ending in two spines of about equal size; palp also tipped with two small and equal spines and situated on the ventral surface near the center.

Maxillipeds with a swollen basal joint, armed with powerful muscles, having a stout spine at the center of the inner margin and a rounded elevation covered with short spiny teeth at the distal end of the same margin. Terminal claw slender and a little more than half the length of the basal joint, with a short accessory spine near the tip.

Color a clear yellowish-white, without pigment.

Total length, $3.45 \mathrm{~mm}$. Cephalothorax, $1.65 \mathrm{~mm}$. long, $0.6 \mathrm{~mm}$. wide. Posterior body, $1.75 \mathrm{~mm}$. long, $1.8 \mathrm{~mm}$. wide. Egg-strings $1 \mathrm{~mm}$. long, $0.7 \mathrm{~mm}$. wide.

(inversus, contrary to the usual order of things, the maxillary glands in this species being outside the maxillæ.)

This is a small and highly interesting species which may be recognized at once by the kidney-shaped knobs on the sides of the cephalothorax at the bases of the second maxillæ.

It is fairly common, having been found on several of the redmouthed grunts, but it is so small and it blends so well with the gill filaments that it is easily overlooked.

BRACHIELLA CONCAVA, new species.

Plate 51, figs. 284-288.

Host and record of specimens.-A single female of this species was taken from the gills of the sting ray, Dasyatis hastata. It was fastened to the gill arch close to its base and on the inner margin away from the gill filaments.

Type-specimen.-Cat. No. 42286, U.S.N.M.

Female.-General body form short and plump; cephalothorax folded back against the dorsal body surface until it is in the same 
straight line with the arms and about the same length as the latter. Head half as wide again as tne neck, nearly cylindrical, and covered on the dorsal surface with a skin-like carapace, which does not reach the anterior margin; neck the same diameter as the arms. Body oval, strongly flattened dorso-ventrally, with the dorsal surface concave or saucer-shaped and its raised margin crenulate. One pair of thick cylindrical processes at the posterior end, on a level with the dorsal surface and well separated. These processes are narrowed to a short neck anteriorly and bluntly rounded posteriorly. They start on either side of the dorsal midline and close to it, and run a short distance at right angles to the body axis, then turn and become parallel with the latter and with each other.

The abdomen and anal laminæ are both lacking. The egg-strings are cylindrical, the same diameter as the posterior processes, and twice as long as the body proper; the eggs are arranged in four or five longitudinal rows, about 50 in a row.

First antennæ very indistinctly segmented, the basal segments much larger than the terminal, the whole appendage turned over ventrally nearly at right angles to the dorsal surface. Second antennæ appressed to the anterior margin of the head, not meeting at the midline, but leaving a gap equal in width to the diameter of the antennæ. Proboscis projecting slightly in front of the head, between the ends of the second antennæ.

First maxillæ short and stout, not reaching beyond the center of the mouth tube, with three terminal spines of about equal length; palp at the center of the inner margin, tipped with two short spines. Second maxillæ about as long as the head and neck, separate to the very ends, where they are slightly enlarged and fused into a rounded knob which supports the bell-shaped bulla.

Maxillipeds with a swollen basal joint, armed on the inner margin near the base with a rounded knob covered with short spines, and a long flexible spine at the center; terminal claw short and weak, with an accessory spine at its base.

Color of the head and neck a clear cartilage gray, the body yellowish, the complicated uterine processes of the oviducts white; egg-strings straw-yellow, becoming deeper as the eggs develop.

Total length, without the egg-strings and posterior processes, $11 \mathrm{~mm}$. Cephalothorax, $6.2 \mathrm{~mm}$. long, $1.4 \mathrm{~mm}$. wide. Arms, $5 \mathrm{~mm}$. long. Posterior processes, $3.2 \mathrm{~mm}$. long. Egg-strings, $7.25 \mathrm{~mm}$.

(concava, hollowed out, alluding to the dorsal surface of the body.)

This species is one of those that have but two posterior processes, and among them may be recognized by the size and shape of those processes, as well as by the large size of the parasite itself. It is not common, since a large number of sting rays yielded but this one specimen. 


\section{Family CANTHOCAMPTIDÆ. \\ CANCRINCOLA, nevv genus.}

Generic characters.-Body made up of 10 segments, slender, cylindrical or somewhat spindle-shaped, the anterior end of the spindle much shorter than the posterior. Cephalic segment short and narrowed anteriorly; rostrum minute and rudimentary. Free thorax segments diminishing slightly but regularly in width from in front backward. Fifth and sixth segments more distinctly separated than in Canthocamptus. First abdomen segment about as wide as the genital segment, the two others somewhat narrower; anal laminæ short and rather stout, each bearing an enormous curved seta, half as long as the entire body or more; no anal opercle.

Anterior antennæ stout and thickset, eight-jointed, those of the male strongly hinged. Posterior antennæ short, the outer ramus very small and one-jointed; mandibular palp simple and also onejointed.

Anterior maxillæ with well-defined endopod and exopod, the latter armed with a stout, claw-like spine; posterior maxillæ with only a single digitiform lobe inside the claw-bearing joint; maxillipeds normally developed.

First swimming legs with the inner ramus two-jointed, much longer than the outer one, and modified for clasping; other swimming legs with the outer ramus longer than the inner, both rami threejointed; fifth pair in the female distinctly lamellar, with the basal joint expanded on the inner side. Only a single ovisac.

Type species - Cancrincola jamaicensis, new species.

(Ćancrincola, cancer, a crab, and incola, dweller or inhabitant.)

CANCRINCOLA JAMAICENSIS, new species.

Plate 50, fig. 281; fig. 51, figs. 282, 3; plate 52.

Type--One female, Cat. No. 43506, U.S.N.M., taken from the gills of the white land crab, Cardisoma guanhumi, at Montego Bay. Paratypes, 30 specimens, including both sexes, taken from the same host, Cat. No. 43593 , U.S.N.M.

Female.-Body slender, more than four times as long as wide, cylindrical, tapering gradually posteriorly. Cephalic segment slightly longer than the two following segments combined, strongly narrowed anteriorly; rostrum very small and triangular. Eye well developed and placed far forward.

First free segment a trifle wider than the cephalon and considerably longer than any of the following segments; fifth and sixth segments distinctly separated; first abdomen segment wider and longer than either of the two which follow it; terminal segment deeply incised at the center and without any anal opercle. 
Anal laminæ much shorter than the terminal segment and thickset, each armed with three short spines at the outer distal corner and two similar ones at the inner distal corner. Between these on the end of each lamina is attached a stout seta five-ninths as long as the entire body; each seta is curved outward at the center, the two resembling a pair of parenthesis marks.

Anterior antennæ indistinctly eight-jointed, considerably shorter than the cephalon, and thickset; the four basal joints are well supplied with setæ of moderate size, on the four terminal joints the setæ are scattering, except a tuft at the very tip; the fourth joint projects somewhat on the anterior margin and is there armed with two long and narrow æsthetasks.

The posterior antennæ are of moderate size, the basal joint with a single small spine on its inner margin; exopod attached at the center of the outer margin, short, one-jointed, and terminating in three setæ, the longest of which is posterior; terminal joint two-thirds the length of the basal, armed with a double row of saw teeth (proximal portion) and three toothed spines (distal portion) along its inner margin; three long spines toothed near their tips, and a shorter one toothed at its center, are attached to the distal margin of this terminal joint.

Mandibles peculiar, the outer ramus very small, simple, one-jointed, and terminating in two long and two short spines, the two former between the two latter; inner ramus flattened into a semicylindrical lamina or blade, the distal end of which is narrower than the basal; cutting portion projecting from the inner surface of this lamina at the distal end as a short, sharp, and toothed process. The concave surfaces of the laminæ face each other so that, when the mandibles are closed together, the laminæ form a short conical tube or proboscis, through which liquid food might well be conveyed to the mouth.

First maxillæ with an exopod made up of one stout curved spine and two smaller ones; endopod a flattened lamina, terminated by a row of short spines. Second maxillæ with a stout exopod terminating in a long curved claw; endopod shorter, with a tuft of small spines at the end.

Maxillipeds with a short and stout basal joint, a swollen second joint, and a slender terminal claw, curved to fit the surface of the second joint and toothed along its inner margin. First four pairs of legs biramose; endopod of the first pair twice the length of the exopod, two-jointed, the basal joint almost four times as long as the terminal, the latter ending in a stout claw and a long slender seta, the former with a long seta on its ventral surface and a shorter one on its outer margin. Exopod of first pair and both rami of the second, third, and fourth legs three-jointed, the spines and setæ arranged 
as follows: First exopod, III $-0, \mathrm{IV}-5, \mathrm{~V}-2$; second endopod, III-1, IV-1, IV-3. Second exopod, II-0, IV-1, IV-4; third endopod, II-1, III-1, VI-4; third exopod, I-0, I-1, $\mathrm{IV}-3$; fourth endopod, $0-1$, III $-0, \mathrm{IV}-4$. Fourth exopod, I-0, $\mathrm{V}-0$, VI-2. Fifth legs uniramose, lamellar, two-jointed, the basal joint with a single seta on the outer side and expanded on the inner side into a broad lamina terminated by four setæ; distal joint narrow oblong, terminated by four slender setæ.

No females were found with attached egg-cases, but the external opening of the oviducts was single, showing that there can be but a single egg-case.

Total length, exclusive of setæ, $0.8 \mathrm{~mm}$. Greatest width (first free thorax segment), $0.175 \mathrm{~mm}$. Length of anal setæ, $0.425 \mathrm{~mm}$.

Color a uniform transparent white, the ovaries and digestive tube somewhat darker in color.

Male.-General form similar to that of the female with the following differences: Cephalon proportionally much longer and wider at its posterior end than any of the succeeding portions of the body. First free segment with a conspicuous indentation on either side near the anterior margin; anal setæ only one-third the length of the body.

First antennæ distinctly hinged, the second and fourth joints meeting on the anterior margin, both of them heavily armed with setæ and with a single large æsthetask at the distal end of the fourth joint; third joint seen only on the posterior margin and unarmed. Mouth parts and first legs like those of the female; second, third, and fourth legs with the endopods less distinctly segmented, the last two joints especially being often more or less fused, but with the number of setæ and spines practically the same and similarly arranged; fifth legs much smaller than in the female, reduced to a simple tiny process tipped with two short setæ.

Total length, $0.88 \mathrm{~mm}$. Greatest width (posterior margin of the cephalon), $0.17 \mathrm{~mm}$. Anal setæ, $0.33 \mathrm{~mm}$. long.

Color like that of the female.

(jamaicensis, a native of Jamaica.)

These tiny copepods are common on the gills of the white land crab of Jamaica, nearly every specimen examined being infested with them. They cling to the gill filaments with their second antennæ and maxillipeds, but are dislodged much more easily than the Ergasilidæ or other small copepods that fasten similarly on the gill filaments of fishes. As many as 25 or 30 may sometimes be obtained from the gills of a single crab. In connection with their parasitism upon this host several extremely interesting questions arise which can not be finally settled without considerable further observation. But there 
are certain facts already definitely known, and from these we may draw some conclusions:

1. The host is a land crab which lives for $11 \frac{1}{2}$ months out of the water, and only resorts to the ocean once a year for a week or 10 days, in order that its eggs may hatch into the customary free-swimming zœas. Hence while its gills are always necessarily moist enough to keep the copepod alive, there is no chance for the latter to do any swimming or to lay its own eggs except during this week or 10 days. This copepod therefore must be content with one breeding season a year, instead of the two or three which its kind ordinarily enjoy.

2 . The copepod's eggs must be ripened and ready to push out into the external sac at the exact time that the crab's eggs are ready to hatch. Hence the extrusion of the copepod's eggs, their development into larvæ, the escape of the latter in the form of nauplii, their development through the various metanauplius and copepodid or cyclops stages to the adult form, and the fastening of the latter on the gills of a crab host must all be accomplished within the short period that the crabs remain in the ocean. If this be true, such a development is exceptionally rapid and is followed by a whole year of rest before the female can lay her first batch of eggs. If it is not true, the copepod remains a free swimmer during the first year of its existence and then becomes parasitic. It must thus lay its first batch of eggs while swimming about freely or wait two years for that occasion. In all the crabs captured before going into the ocean the female copepods were found to have their oviducts crowded with ripe eggs all ready for extrusion. On the contrary, not a single egg could be found in the oviducts of copepods taken from crabs that had come out of the ocean.

3. This copepod can not move around much on the crab's gills when the latter is out of the water, and no food can possibly be brought to it. Hence it must feed upon the blood in the gills, the slime that covers them, or something of the sort that can be obtained in sufficient abundance in situ. This means that it is parasitic and not commensal. The peculiar modification of the mandibles into a sort of proboscis or mouth tube and their sharp, toothed tips would corroborate such an inference.

4. It would naturally be supposed that such rigorous conditions could only be met by a copepod belonging to some thoroughly parasitic family, and we should look for considerable modification as the result of its degenerate habits. But what we really do find is as far removed from this as possible. Cancrincola belongs to a group, the Harpacticoida, which has always been considered to be typical free swimmers, and no member of the group has hitherto been known to live under any other conditions. 
It is therefore remarkable that this single exception should depart so radically from the habits of its relatives. And then, in spite of the parasitism, it is still normally developed like all the other genera in the group and it has lost none of its ability to swim freely. Its life history, when fully worked out, ought to possess unusual interest.

\section{PARASITIC OSTRACODS.}

Very little is known with reference to the habits of the ostracods. The earlier authors like Linnæus, Geoffroy, Fabricius, O. F. Müller, Desmarest, and even Milne Edwards give a variety of details with regard to the different genera and species. But they are all content with a very few general observations on their habits and mode of life.

Baird (1850) was the first to give us any real knowledge of the food and activities of these entomostracans. But although he said that "most of the entomostraca are essentially carnivorous," and gave numerous examples of species which hunt and kill their prey, he made no mention of any ostracod that was parasitic.

In Brady's Report on the Ostracods of the Challenger Expedition nothing is said with regard to their food, but he mentions the fact that the Cypridinæ "appear to be most abundant in the warm surface waters of the tropical seas, contributing largely to the phosphorescence of those regions." He also calls attention to the fact that only the males can swim, the females lacking the rowing setæ on the antennæ, and in consequence living at the bottom in the sand or mud (p. 151).

G. W. Müller in his monograph on the Ostracods, which constitutes the twenty-first volume of the Fauna and Flora of the Bay of Naples, when speaking of their food, mentions finding diatom shells in the stomachs of some species, while he found one-celled algæ and the setæ of some small crustacea in the stomach of another species. A representative of the genus Macrocypris, kept in captivity, ate freely of small dead copepods, and Conchcecia spinirostris had in its stomach the apparent remains of copepods.

A young Cypridina mediterranea, while in captivity, ate greedily of a small dead annulate. Such observations as these suggest that a carnivorous ostracod might very well become parasitic under favorable conditions. It would not necessitate very much of a change in habits or structure.

And finally, in Lankester's Treatise on Zoology, Calman, who wrote the volume dealing with the Crustacea (1909), devotes only a few lines to the habits of the ostracods, in which he says: "None are definitely known to be parasitic, but one species found in the gill chambers of crayfish in North America may be so" (p. 67). 
In view of these statements, it will be of special interest to record the discovery of a new species of Cypridina, parasitic upon the gills of several kinds of fish.

That the presence of these ostracods on the fishes' gills was not accidental is abundantly proven by the following considerations: First there were too many of them; one or two or half a dozen might be washed on to the gills of a fish accidentally, but not 40 or 50 . Again they were arranged altogether too regularly; in the space between the bases of two adjacent filaments and in contact with the gill arch, there was always a single ostracod, its long diameter at right angles to the gill arch, so that its anterior end projected slightly on one side between the filaments, and its posterior end on the other side.

Furthermore the tissues of each filament where they came in contact with the shell of the ostracod, were hollowed out in the center and slightly raised around the edges, thus forming a sort of pocket, which held the ostracod securely in place so that it could be removed only with a pair of forceps. This of course is absolute proof that the ostracod was not washed in temporarily, but that it had remained in position long enough to produce this effect on the tissues. In view of such conditions these ostracods may fairly be called parasitic. While it is impossible to see how they can draw any blood from the fish's gills, yet they certainly share the oxygenated water with which the fish keeps its gills supplied, and they get their food in some way while there. For food they may devour anything that the water contains and brings to them, they may eat scraps of the fish's food that come their way, or they may feed on the slime with which the fish's gills are covered. It is impossible to determine at present just what does constitute their diet.

\section{CYPRIDINA PARASITICA, new species.}

Plate 53.

Host and record of specimens.-Five lots of this ostracod were obtained in all; two of these were taken from the gills of two hammerhead sharks, Sphyrna zygæna, on July 9, and include about 50 specimens each. They have received the numbers 43581 and 43586 , U.S.N.M., and become paratypes of the new species. The third lot contains a single specimen found on the gills of Epinephelus adscensionis, August 9, and is numbered 43599, U.S.N.M.

The fourth lot contains three specimens taken from the gills of a jack, Caranx crysos, August 1, and is numbered 43604, U.S.N.M. The fifth lot contains 12 specimens and was obtained from the nasal tubes of the hammer-head shark on June 17, and is numbered 43603, U.S.N.M.

Type-specimen.-Male, Cat. No. 43508, U.S.N.M., from one of the hammer-head sharks. 
Male.-Shell subovate, greatest height posterior to the center, ventral and dorsal margins evenly rounded; posterior end formed by the continued even sweep of the dorsal margin, but with the lower portion protruding somewhat as in C. mediterranea. Antennal sinus narrow and not very deep, with parallel sides; rostrate process wide, well arched anteriorly, acute at the point and directed downward and slightly backward. Eye large and at about the center of the shell dorso-ventrally but considerably in frontof the anteroposterior center. Length of shell, $1.8 \mathrm{~mm}$; height, $1.15 \mathrm{~mm}$.

Antennules rather stout; terminal joint with three long setæ of equal length; sensory appendage on the fifth joint long, distinctly ringed and divided at the tip, its secondary filaments short and flattened. Antennæ of the usual form, swimming branch bearing nine setæ, the basal one much shorter than the others; appendicular branch witha very short basal seta and a long and stout terminal one, carrying a short secondary seta on its inner margin. Hirsute masticatory lobe of the mandibles large and prominent; basal joint of the palp considerably swollen; subterminal joint about half the entire length, terminal claws stout and of the same size.

First maxilla broad and stout, with a long and slender palp, thickly armed with setæ at its tip; second maxilla rather slender with broad and flattened setæ; vibratory lamina narrow, its setæ increasing in length from the tip toward the base; third maxilla wide and stout, vibratory lamina broadly triangular and armed with two long setæ at the outer corner and six shorter ones along the basal portion of the anterior margin, with a considerable space between the two devoid of armature. Vermiform leg armed with 10 to 12 very slender cilia along either margin and one or two at the end. Caudal lamina with 14 spines, gradually increasing in length from the base toward the tip, the last three much shorter than the others and of nearly the same length.

Female unknown.

\section{LIST OF HOSTS, WITH PARASITES FOUND ON EACH.}

SPHYRNA ZYGENA. Hammerhead shark.

Ergasilus myctarothes $\mathrm{W}$ ilson, living in the nasal tubes.

Tæniacanthus flagellans Wilson, from the gill cavities close to the edge of the gill filaments.

Lepeophtheirus longispinosus Wilson, from the inside of the gill cavity.

Nemesis versicolor $\mathrm{W}$ ilson, attached to the gill filaments.

Cypridina parasitica Wilson, the ostracod, between the gill filaments at their base.

DASYATIS HASTATA. Sting ray.

Brachiella concava Wilson, from the gill arches.

HEMIRAMPHUS BRASILIENSIS. Balao.

Lernæolophus hemiramphi Krøyer, from the mouth opening.

EXOCETUS VOLITANS. Flying fish.

Pennella exocoti(Holten), with its head and anterior body buried in the flesh along the side of the fishs' body. 
SPHYRAENA BARRACUDA. The barracuda.

Caligus productus Dana, from the outside of the body.

Caligus isonyx Steenstrup and Lütken, from the gills.

Midias lobodes Wilson, from the outside of the body and head.

Lernæolophus striatus Wilson, from the inside of the throat.

CARANX HIPPOS. The jack.

Caligus tenax Heller, attached to the gill filaments.

Lernanthropus giganteus Krøyer, attached to the gill filaments and arches.

CARANX CRYSOS. The yellow jack.

Pseudoeucanthus uniseriatus Wilson, from the gills and mouth cavity.

Caligus tenax Heller, from the mouth.

Caligus robustus Bassett-Smith, from the gill filaments.

Lernanthropus giganteus Krøyer, from the gills.

Cypridina parasitica Wilson, the ostracod, between the gill filaments at their base.

CORYPH ENA HIPPURUS. The dolphin.

Caligus productus Dana, from the outside surface of the body.

Euryphorus coryphænæ Krøyer, from the gills.

EPINEPHELUS ADSCENSIONIS. The rock hind.

Sagum flagellatum, a new genus and species, attached to the gill arch.

Hatschekia insolita W ilson, fastened to the outside of the gill filaments.

Hatschekia uncata Wilson, fastened between the gill filaments at their base.

EPINEPHELUS MORIO. The red grouper.

Lepeophtheirus dissimulatus Wilson, from the outside surface.

MYCTEROPERCA VENENOSA APUA. The cardenal or poison grouper.

Dentigryps curtus, a new genus and species, found in the mouth and gill cavities.

SERRANUS (species not given).

Lernanthropus angulatus Krøyer, found on the gills.

Therodamas serrani Krøyer, also from the gills.

NEOMAENIS AYA. The red snapper.

Caligus irritans Heller, from the gill filaments.

Paralebion curticaudis Wilson, from the gill arches.

Lernanthropus frondeus Wilson, from the gill filaments.

Hatschekia oblonga Wilson, also from the gill filaments.

Thysanote longimana Wilson, from the outside of the throat.

NEOM ENIS SYNAGRIS. The lane snapper.

Lernanthropus spiculatus Wilson and Hatschekia albirubra Wilson, both from the gill filaments.

HEMULON SCIURUS. The yellow grunt.

Caligus hæmulonis Krøyer, from the gills.

OCYURUS CHRYSURUS. The yellow-tail.

Lernanthropus obscurus Wilson, and Hatschekia albirubra Wilson, both from the gill filaments.

BATHYSTOMA RIMATOR. The red-mouthed grunt.

Caligus robustus Bassett-Smith, from the gills.

Hatschekia linearis Wilson, also from the gills.

Clavella inversa Wilson, from the gill cavity.

ABUDEFDUF SAXATILIS. The sheepshead.

Bomolochus nothrus Wilson, from the gill cavity.

SPARISOMA VIRIDE. The green parrot-fish.

Caligus afurcatus Wilson, fastened in the spaces between adjacent filaments.

Caligus enormis Wilson, clinging to the inside of the gill filaments.

SCARUS CEERULEUS. The blue parrot-fish.

Caligus suffuscus Wilson, from the mouth cavity.

Lernxolophus recurvus Wilson, fastened to the gill arches.

HARPE RUFA. The Spanish lady-fish.

Lepeophtheirus cossyphi Krøyer, from the gills.

POMACANTHUS ARCUATUS. The black angel-fish.

A nuretes parvulus Wilson, from the gill filaments.

TEUTHIS HEPATUS. The doctor-fish.

Caligus atromaculatus Wilson from the gills.

Hatschekia linearis Wilson, attached to the gill illaments.

Clavella laciniata Krøyer, from the skin of the roof of the mouth.

BALISTES VETULA. The trigger-fish.

Caligus productus Dana, from the outside surface of the body.

Caligus balistæ Steenstrup and Lütken, from the mouth cavity and the fins. 
POMACANTHUS PARU. The Indian or flat-fish.

Thysanote pomacanthi Kroyer, from the gills.

MONACANTHUS HISPIDUS. The file-fish.

Caligus monacanthi Kroyer, from the outside skin.

ALEUTERA SCRIPTA. The tobacco-fish.

Bomolochus nothrus Wilson, from the gill filaments.

SPHEROIDES MARMORATUS. The spiny-backed puffer.

Tucca impressus Krøyer, from the pectoral fins.

DIODON HYSTRIX. The porcupine-fish.

Tucca impressus Krøyer, from the pectoral fins.

Hatschekia iridescens Wilson, from the gill filaments.

CHLOMYCTERUS ANTENNATUS. The spiny puffer.

Ergasilus longipalpus Wilson, from the gill filaments.

Tucca impressus Krøyer, from the pectoral fins.

SCORPAENA PLUMIERI. The scorpion-fish.

Bomolochus attenuatus Wilson, and Artacolax palleucus Wilson, both attached to the gill filaments.

CARDISOMA GUANHUMI. The white land crab.

Cancrincola jamaicensis, a new genus and species, from the gills.

\section{EXPLANATION OF PLATES.}

Plate 18.

Females of Ergasilus longipalpus, and Ergasilus myctarothes.

Fig. 1. Dorsal view of E. longipalpus. Fig. 2. Mouth parts; md, mandibles; $m x^{1}$ and $m x^{2}$, first and second maxillæ. Figs. 3 to 6 . First, second, third, and fourth swimming legs. Fig. 7. Dorsal view of E. myctarothes. Fig. 8. Mouth parts. Fig. 9. Ventral view of abdomen. Figs. 10 to 12 . First, third, and fourth swimming legs.

Plate 19.

Male and female of Bomolochus nothrus.

Fig. 13. Dorsal view of female. Fig. 14. Second antenna. Fig. 15. Mouth parts; $l b$, upper lip; $m d$, mandible; $m x^{1}$ and $m x^{2}$, first and second maxillæ; $m x p$, maxilliped. Figs. 16 to 20 . First, second, third, fourth, and fifth swimming legs. Fig. 21. One of the claws on the exopods of the legs of the male.

Plate 20.

Male of Bomolochus nothrus.

Fig. 22. Dorsal view. Fig. 23. Mouth parts; $a n^{2}$, second antennæ, other lettering as before. Figs. 24 to 27 . First, second, third, and fourth swimming legs.

Plate 21.

Female of Bomolochus attenuatus.

Fig. 28. Dorsal view. Fig. 29. Second antenna. Fig. 30. Mouth parts, lettering as in fig. 15. Figs. 31 to 34 . First, second, third, and fourth swimming legs.

\section{Plate 22.}

Male and fomale of Artacolax palleucus,.

Fig. 35. Dorsal view of male.w is. 36 to 38 . First, third, and fourth swimming legs. Fig. 39. Dorsal view of feinale. Figs. 40 and 41. First and second swimming legs. 
Plate 23.

Mouth parts and swimming legs of Artacolax palleucus.

Figs. 42 and 43. Third and fourth swimming legs of female. Fig. 44. Mouth parts of female. Fig. 45. Mouth parts of male. (For lettering, see fig. 15.)

Plate 24.

Female of Pseudoeucanthus uniseriatus.

Fig. 46. Dorsal view of female. Fig. 47. Second antenna. Fig. 48. Mouth parts. Figs. 49 to 53. First, second, third, fourth, and fifth swimming legs.

\section{Plate 25.}

Female of Tæniacanthus flagellans, and leg of Caligus irritans.

Fig. 54. Dorsal view of female. Fig. 55. First antenna. Fig. 56. Mouth parts. (For lettering, see fig. 15.) Figs. 57 to 60. First, second, third, and fourth swimming legs. Fig. 61. Side view of female, showing how the cephalon projects at right angles to the rest of the body. Fig. 62. Fourth leg of Caligus irritans.

\section{Plate 26.}

\section{Female of Caligus tenax.}

Fig. 63. Dorsal view. Fig. 64. Second antennæ and maxillary hooks. Fig. 65. Maxilliped. Figs. 66 to 69. First, second, third, and fourth swimming legs. Fig. 70. Second antenna and maxillary hook of male. (For lettering, see fig. 15.)

Plate 27.

Male and female of Caligus irritans.

Fig. 71. Dorsal view of male. Fig. 72. Second antenna, maxillary hook, maxilla maxilliped, and furca of male. Fig. 73. Dorsal view of female. Fig. 74. Second antenna, maxillary hook, first maxilla, and mouth tube of female. Fig. 75. Maxilliped. Fig. 76. Furca. Figs. 77 to 79. First, second, and third swimming legs. Fig. 80. Cement glands, ventral view.

\section{Plate 28.}

Male and female of Caligus robustus.

Fig. 81. Dorsal view of female. Fig. 82. Second antenna, maxillary hook, and first maxilla. Fig. 83. Furca. Fig. 84. Maxilliped. Figs. 85 to 88. First, second, third, and fourth swimming legs. Fig. 89. Dorsal view of male. Fig. 90. Maxilliped. Fig. 91. Fourth swimming leg.

Plate 29.

Female of Caligus atromaculatus, and male and female of Caligus tenax.

Fig. 92. Dorsal view of female of $C$. atrom us. Fig. 93. Second antenna and first maxilla. Fig. 94. Maxilliped. Fig. 9e rca. Figs. 96 to 98 . First, second, and fourth swimming legs. Fig. 99. Dorsaı view of male of C. tenax. Fig. 100. Furca. Fig. 101. Cement glands of female C. tenax. 
Plate 30.

Females of Caligus afurcatus, and C. suffuscus.

Fig. 102. Dorsal view of female of $C$. afurcatus. Fig. 103. Second antenna, maxillary hook, and first maxilla. Fig. 104. Maxilliped. Fig. 105. Third swimming leg. Fig. 106. Cement glands. Fig. 107. Dorsal view of female of C. suffuscus. Fig. 108. Second antenna and maxillary hook. Fig. 109. First maxilla. Fig. 110. Maxilliped. Fig. 111. Furca. Figs. 112 to 115. First, second, third, and fourth swimming legs.

Plate 31.

\section{Male and female of Caligus enormis.}

Fig. 116. Dorsal view of female. Fig. 117. Second antenna and maxillary hook. Fig. 118. First and second maxillæ and mouth tube. Figs. 119 to 122 . First, second, third, and fourth swimming legs. Fig. 123. Dorsal view of male. Fig. 124. Second antenna and maxillary hook. Fig. 125. Maxilliped of male. Fig. 126. Maxilliped of female.

\section{Plate 32.}

Female of Dentigryps curtus, and swimming legs of Caligus afurcatus.

Fig. 127. Dorsal view of female of Dentigryps curtus. Fig. 128. Second antenna and maxillary hook. Fig. 129. Mouth tube and first maxilla. Fig. 130. Maxilliped. Fig. 131. Furca. Figs. 132 to 134. First, third, and fourth swimming legs. Fig. 135. Ventral view of posterior end of genital segment and abdomen. Figs. 136 to 138. First, second, and fourth swimming legs of Caligus afurcatus.

Plate 33.

Female of Anuretes parvulus, and of Lernanthropus giganteus.

Fig. 139. Dorsal view of Anuretes parvulus. Fig. 140. First antenna. Fig. 141. Second antenna. Fig. 142. First maxilla and mouth tube. Fig. 143. Maxilliped. Figs. 144 to 146. First, second, and third swimming legs. Fig. 147. Ventral view of genital segment and abdomen. Fig. 148. Ventral view of cephalothorax of female Lernanthropus giganteus. Fig. 149. Ventral view of genital segment and abdomen of same, showing fifth leg and attachment of spermatophore (sp.). Fig. 150. Same view of another specimen, showing irregular arrangement of eggs.

\section{Plate 34.}

\section{Female of Paralebion curticaudis.}

Fig. 151. Dorsal view. Fig. 152. Second antenna, maxillary hook and first maxilla. Fig. 153. Second maxilla. Fig. 154. Maxilliped. Fig. 155. Furca. Figs. 156 to 159. First, second, third, and fourth swimming legs. Fig. 160. Ventral view of genital segment, showing cement glands. Fig. 161. Posterior lobe of genital segment, showing fifth leg and origin of egg-tube.

\section{Plate 35.}

Male and female of Lernanthropus giganteus.

Fig. 162. Dorsal view of female. Figs. 163 and 164. First and second swimming legs. Fig. 165. Dorsal view of male. Fig. 166. Second antennæ. Fig. 167. Mouth tube, maxillæ, maxilliped, and first and second swimming legs of male. 


\section{Plate 36.}

\section{Male and female of Lernanthropus frondeus.}

Fig. 168. Dorsal view of female. Fig. 169. Second antenna. Fig. 170. Mouth tube and first maxillæ. Fig. 171. Maxilliped. Fig. 172. Ventral view of genital segment and abdomen, showing leaf-like fifth legs and anal laminæ. Figs. 173 and 174. First and second swimming legs. Fig. 175. Dorsal view of male. Fig. 176. First antenna. Fig. 177. Maxilliped.

\section{Plate 37.}

Male and female of Lernanthropus obscurus.

Fig. 178. Dorsal view of female. Fig. 179. Second antenna. Figs. 180 and 181. First and second swimming legs. Fig. 182. Dorsal view of male. Fig. 183. Mouth tube, mouth parts, and swimming legs of female. ( $m$, mouth; 1 , first swimming leg; 2, second swimming leg. For other lettering see fig. 15.) Fig. 184. Same of male. (For lettering see fig. 183.)

\section{Plate 38.}

Female of Lernanthropus spiculatus new species, and Nemesis versicolor.

Fig. 185. Dorsal view. Fig. 186. Second antenna. Fig. 187. Mouth tube and first and second maxillæ. Fig. 188. Maxilliped. Fig. 189. Ventral view, showing swimming legs. Fig. 190. Second antenna of Nemesis versicolor. Figs. 191 to 194. First, second, third, and fourth swimming legs of same.

\section{Plate 39.}

\section{Female of Sagum flagellatum.}

Fig. 195. Dorsal view. Fig. 196. Ventral view. Fig. 197. First and second antennæ, mouth parts, and swimming legs, enlarged. (an ${ }^{1}$, first antenna; $a n^{2}$, second antenna; 1, first swimming leg; 2, second swimming leg; other lettering as before.) Fig. 198. One of the fourth swimming legs, showing structure. Fig. 199. Ventral view genital segment and abdomen.

Flate 40.

Male and female of Nemesis versicolor.

Fig. 200. Dorsal view of female. Fig. 201. Second maxilla. Fig. 202. Dorsal view of male. Fig. 203. First and second antennæ. Fig. 204. First and second maxillæ and maxilliped. Fig. 205 to 208. First, second, third, and fourth swimming legs.

Plate 41.

Female of Hatschekia albirubra, and H. iridescens.

Fig. 209. Dorsal view of female of $H$. albirubra. Fig. 210. First antenna. Fig. 211. Second antenna. Fig. 212. First maxilla. Fig. 213. Maxilliped. Figs. 214 and 215. First and second swimming legs. Fig. 216. Nauplius of H. iridescens. Fig. 217. First antenna of female $H$. iridescens. Fig. 218. Mouth tube and maxilla. Fig. 219. Maxilliped. Tigs. 220 and 221. First and second swimming legs.

\section{Plate 42.}

Females of Hatschekia oblonga, and of $H$. insolita.

Fig. 222. Dorsal view of female H. oblonga. Fig. 223. Second antenna. Fig. 224. Maxilliped. Figs. 225 and 226. First and second swimming legs. Fig. 227. Dorsal viəw of female $H$. insolita. Fig. 228. Second antenna. Fig. 229. Mouth tube and first maxillæ. Fig. 230. Maxilliped. Figs. 231 and 232. First and second swimming legs. 


\section{Plate 43.}

\section{Female of Hatschekia uncata.}

Fig. 233. Dorsal view of female. Fig. 234. Second antenna. Fig. 235. Maxilliped. Fig. 236. Mouth tube and maxillæ. Figs. 237 and 238. First and second swimming legs. Fig. 239. Fused genital segment and abdomen.

Plate 44.

Female of Hatschekia linearis, and male of $H$. iridescens.

Fig. 240. Dorsal view of female of H.linearis. Fig. 241. First antennæ. Fig. 242. Maxilla and maxilliped. Fig. 243. Second antenna. Figs. 244 and 245. First and second swimming legs. Fig. 246. Ventral view, showing oviducts, cement glands, and fused genital segment and abdomen. Fig. 247. Dorsal view of male H. iridescens.

\section{Plate 45.}

Female of Hatschekia iridescens.

Fig. 248. Dorsal view of female. Fig. 249. First antenna of male. Fig. 250. Second antenna of female. Fig. 251. Second antenna of male. Fig. 252. Maxilliped of female. Figs. 253 and 254. First and second swimming legs of male. Fig. 255. Ventral view of female, showing cement glands (c. g.), oviducts (ov.), spermatophore (sp.), and sperm receptacle (s.r.).

\section{Pláte 46.}

Female of Lernæolophus recurvus.

Fig. 256. Side view of young female. Fig. 257. Ventral view of head and upper portion of thorax, showing mouth parts and swimming legs. (la, underlip; other lettering as before.) Fig. 258. Diagonal view of head and mouth parts. (Lettering as before.) Fig. 259. Side view of adult female, showing branched processes and the densely matted dichotomous processes of the abdomen.

\section{Plate 47.}

Fomale of Lernæolophus striatus, and Thysanote longimana.

Fig. 260. Dorsal view of L. striatus. Fig. 261. Ventral view of cephalothorax, showing mouth parts and swimming legs. (Lettering as before.) Fig. 262. Side view of male of $T$. longimana, showing antennæ and mouth parts. (Lettering as before.) Fig. 263. Second antenna of female. Fig. 264. Maxilliped of female.

\section{Plate 48.}

Male and female of Thysanote longimana.

Fig. 265. Dorsal view of female. Fig. 266. Ventral view of head, showing mouth tube and maxillæ. Fig. 267. First antenna. Fig. 268. Maxilla. Fig. 269. Side view of male.

\section{Plate 49.}

\section{Male and female of Clavella laciniata}

Fig. 270. Side view of female. Fig. 271. Second antenna. Fig. 272. Maxilla. Fig. 273. Maxilliped. Fig. 274. Side view of male. 


\section{Plate 50.}

Female of Clavella inversa, and male of Cancrincola jamaicensis.

Fig. 275. Side view of female. Fig. 276. Front view of cephalothorax, showing mouth tube and mouth parts (above), and second maxillæ (below). Fig. 277. Base $o_{f}$ second maxillæ, enlarged, showing maxillary glands. Fig. 278. Ventral view of head. (Lettering as before.) Fig. 279. Maxilla. Fig. 280. Maxilliped. Fig. 281. Fourth swimming leg of male of Cancrincola jamaicensis, new genus and species.

\section{Plate 51.}

Cancrincola jamaicensis, and female of Brachiella concava.

Figs. 282 and 283. Third swimming leg of male and fifth swimming leg of female, Cancrincola jamaicensis. Fig. 284. Side view of female Brachiella concava. Fig. 285. Dorsal view of genital segment of same, showing posterior processes. Figs. 286 and 287. Side and ventral views of anterior part of head, showing antennæ and mouth parts. (Lettering as before.) Fig. 288. Maxilliped.

\section{Plate 52.}

Male and female of Cancrincola jamaicensis.

Fig. 289. Dorsal view of male. Fig. 290. First antenna. Fig. 291. Fifth swimming leg. Fig. 292. Dorsal view of female. Fig. 293. First antenna. Fig. 294. Second antenna. Fig. 295. Mandible. Fig. 296. First maxilla. Fig. 297. Second maxilla. Fig. 298. Maxilliped. Figs. 299 to 302. First, second, third, and fourth swimming legs.

\section{Plate 53.}

\section{Male of Cypridina parasitica.}

Fig. 303. Side view of male. Fig. 304. First antenna. Figs. 305 and 306. Second antenna, dorsal and ventral views. Fig. 307. Mandible. Fig. 308. First maxilla. Fig. 309. Second maxilla. Fig. 310. Third maxilla. Fig. 311. Vermiform swimming leg, and caudal lamina. 


\section{$2 \mathrm{BHL}$ Biodiversity Heritage Library}

Wilson, Charles Branch. 1913. "Crustacean parasites of West Indian fishes and land crabs, with descriptions of new genera and species." Proceedings of the United States National Museum 44(1950), 189-277. https://doi.org/10.5479/si.00963801.44-1950.189.

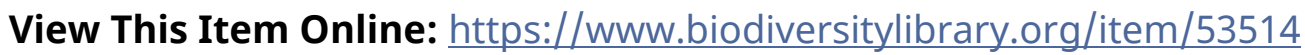
DOI: https://doi.org/10.5479/si.00963801.44-1950.189

Permalink: https://www.biodiversitylibrary.org/partpdf/52475

\section{Holding Institution}

Smithsonian Libraries

\section{Sponsored by}

Smithsonian

\section{Copyright \& Reuse}

Copyright Status: Public domain. The BHL considers that this work is no longer under copyright protection.

This document was created from content at the Biodiversity Heritage Library, the world's largest open access digital library for biodiversity literature and archives. Visit BHL at https://www.biodiversitylibrary.org. 